\title{
ALTERACIÓN DE LAS CIRCUNSTANCIAS Y REVISIÓN CONTRATUAL
}

\section{TESIS DOCTORAL}

ROBERTO FERNANDES DE ALMEIDA

Dirigido por el

PROF. DR. EUGENIO LLAMAS POMBO

Programa de Doctorado en Derecho Privado UNIVERSIDAD DE SALAMANCA 


\section{ALTERACIÓN DE LAS CIRCUNSTANCIAS Y REVISIÓN CONTRATUAL}

Tesis doctoral

Programa de Doctorado en Derecho Privado ("Nuevas Tendencias em Derecho Privado") de la Universidad de Salamanca, por Roberto Fernandes de Almeida - Dirección del Prof. Dr. D. Eugenio Llamas Pombo.

Salamanca, 2011 
"To strive, to seek, to find and not to yield".

("Ulisses”, by Tennyson) 
Prof. Dr. Eugenio Llamas Pombo

Roberto Fernandes de Almeida - Doctorando 


\section{Agradecimientos}

Deseo agradecer, inicialmente, a mi querido tutor y maestro, Prof. Dr. Eugenio Llamas Pombo, notable docente y jurista. Mi agradecimiento se debe a su cariño, paciencia y cuidados para conmigo a lo largo de toda la orientación para la elaboración del presente trabajo de investigación. Fue una honra sin par ser alumno y orientando de tan sabio profesor. Su postura y calidad docente, es -- y siempre será -para mí, una fuente inagotable de continua e intensa inspiración, especialmente en mis actividades académicas en Brasil. Le expreso aquí, por lo tanto, un 'muchas gracias' de todo corazón.

Agradezco, igualmente, al Prof. Dr. José María León González, por las eruditas enseñanzas y consejos en ocasión de la presentación da mi tesina, a fin de la obtención del título de grado en Salamanca (importante paso intermedio en este curso de doctorado) en su calidad de Presidente del Tribunal correspondiente.

Sus comentarios profundos e instigantes - siempre sabios y pertinentes, sin ninguna falsa erudición, propios de aquellos que mucho saben y que, por eso mismo, desarrollaron la singular modestia y sencillez de los genios - denotan un elevadísimo grado de conocimiento jurídico. Absorber las enseñanzas del Profesor León - tanto en sus clases de doctorado como, puntualmente, en el Tribunal referido es, estoy absolutamente convencido, una bendición para pocos.

Doy también las gracias a la Universidad de Salamanca (aquí, incluyo a todos los demás profesores y a los atentos y competentes empleados de la institución) así como a la propia ciudad de Salamanca, donde fui acogido, a lo largo de todo el período de estudio, investigación y preparación del presente trabajo, siempre bien y donde se me hizo sentir como si estuviera en mi casa. 
Por otra parte, nunca está demás afirmar que la ciudad de Salamanca es especial, singular y única. Y no lo digo yo, sino que me autorizo a citar aquí al maestro de los maestros, Miguel de Cervantes Saavedra, en su libro "El licenciado Vidriera":

"Salamanca que enhechiza la voluntad de volver a ella a todos los que de la apacibilidad de su vivienda han gustado"

Agradezco, también a mi familia, por la gran paciencia, demostrada incontables veces a lo largo del curso de doctorado, personificada en las largas - y casi interminables -- horas hurtadas a la convivencia familiar.

Finalmente, agradezco a Dios y a Jesús Cristo por la oportunidad única - no sintiéndome en lo íntimo, merecedor de tamaña honra -- de permitir que pudiese estudiar en una de las más antiguas y prestigiosas universidades del mundo.

A decir verdad, entiendo que esta alta Casa de Estudios es la primera del mundo ostentar tal condición, conforme, según los historiadores, el edicto de 1253 de Don Alfonso X de Castilla y León y la bula del Papa Alejandro IV, de 1255. Espacio académico por donde pasaron grandes pensadores y notables genios de la humanidad, destacándose, de una lista casi interminable, Antonio de Nebrija, Cristóbal Colón, Abraão Zacuto, Fernando de Rojas, Francisco de Vitoria, Fray Luis de León y el siempre inolvidable Miguel de Unamuno. 


\section{SUMARIO}

\section{Capítulo I}

1. Introducción

2. Consideraciones generales sobre los contratos 16

2.1. Orígenes remotos del contrato 20

2.2. El contrato como fuente de obligaciones 26

3. La constitución del vínculo contractual, autonomía de la voluntad y el consenso de las partes 41

4. La fuerza obligatoria del contrato 44

5. Breve mirada histórica sobre la evolución de los contratos, bajo la óptica de la progresiva expansión económica y la práctica de actos de naturaleza económica en gran escala: Antigüedad, Edad Media, Modernidad y Posmodernidad 
6. La real función del contrato y su efectivo y concreto alcance social 63

6.1. La buena fe contractual como matriz integradora de la función social del contrato 67

\section{Capítulo II}

1. La cláusula "rebus sic stantibus" y la flexibilización de la primacía del "pacta sunt servanda". Breve esbozo histórico de la cláusula "rebus sic stantibus" 85

2. Resurgimiento de la cláusula "rebus sic stantibus" 95 


\section{Capítulo III}

1. El contrato en calidad de experiencia económica y sus riesgos inherentes

2. La alteración de la economía del contrato por la alteración de las circunstancias: el necesario mantenimiento de la equivalencia material de las prestaciones en los contratos de ejecución continuada y de tracto sucesivo 109

2.1 La cláusula "hardship": concepto y aplicabilidad.

\section{Capítulo IV}

1. Principales soluciones propuestas por la doctrina a lo largo del tiempo: Teoría de la Presuposición, Teoría del Hecho Sobreviniente y Teoría de la Base del Negocio Jurídico 
1.3. Teoría de la Base del Negocio Jurídico

1.4. Puntos comunes parciales

2. Criterios objetivos para la aplicación de la Teoría de la Imprevisión (la cuestión de la excesiva onerosidad, frustración de la finalidad del contrato y desaparecimiento de la base del negocio 158

3. Efectos jurídicos de la revisión judicial o de la resolución del contrato

3.1. De la posibilidad de utilización de acción cautelar por el contratante en desventaja 198

\section{Capítulo V}

1. Derecho Comparado en América Latina: la buena como sustento de la aplicación de la Teoría de la Imprevisión en los sistemas jurídicos del subcontinente 203 
2 Las leyes de emergencia en Argentina, en el período de la grave crisis económica de finales del siglo $\mathrm{XX}$ e inicio del siglo XXI 212

2.1. De la revisión de los contratos por alteración de las circunstancias en larga escala en el sistema jurídico argentino 215

\section{Capítulo VI}

1. Diálogo jurisprudencial: recortes de la jurisprudencia de Brasil y de España - Jurisprudencia comparada 225

1.1. La Teoría de la Imprevisión en el Derecho Español _......225

1.2. Aplicación de la Teoría de la Imprevisión en el ámbito de Brasil: algunos fallos que adoptaron esta teoría como razón de decidir 233

Conclusiones 244

Bibliografía 256 


\section{CAPÍTULO I}

1. Introducción

2. Consideraciones generales sobre los contratos

2.1. Orígenes remotos del contrato

2.2. El contrato como fuente de obligaciones

3. La constitución del vínculo contractual, autonomía de la voluntad y el consenso de las partes

4. La fuerza obligatoria del contrato

5. Breve mirada histórica sobre la evolución de los contratos, bajo la óptica de la progresiva expansión económica y la práctica de actos de naturaleza económica en gran escala: Antigüedad, Edad Media, Modernidad y Posmodernidad

6. La real función del contrato y su efectivo y concreto alcance social 


\section{INTRODUCCIÓN}

El punto estructural y de base, que norteará el presente trabajo, es resultado de una amplia e intensa reflexión en relación a los contratos que son celebrados con la presunción de que serán rigurosamente cumplidos, observándose los términos originariamente previstos, posición ésta galvanizada en la vieja máxima de la cláusula "pacta sunt servanda" (en traducción libre, "los contratos deben ser cumplidos”). Esta reflexión, de carácter instigadora, derivó de la práctica y observación diaria del autor de este modesto trabajo acerca del tema, como abogado litigante y profesor universitario de la asignatura Derecho Empresarial (antiguo Derecho Comercial).

Esa disposición, llevada hasta las últimas consecuencias, muchas veces acaba perpetuando, en el contrato respectivo, un cuadro de injusticia y nula equidad, cuando, en el lapso temporal relativo a la efectiva ejecución del pacto firmado y de las obligaciones allí consignadas, sobreviene una significativa alteración de aquellas condiciones primarias que llevaron a las partes contratantes a la ultimación del propio contrato, con alteración de la base del negocio. Estas alteraciones, normalmente vinculadas a una fuerza incoercible de circunstancias externas, comunican el nacimiento de un grave desequilibrio y ausencia de la necesaria equidad en la relación jurídica respectiva, informando el enriquecimiento exagerado de uno de los contratantes en sacrificio del otro. 
La actual concepción de contrato, construida con el transcurrir de sus nobles y crecientes nuevas funciones sociales, desempeñadas en las sociedades de hombres libres y en el propio Estado moderno, pasó a exigir, en este mosaico, por excepción, una atenuación robusta del principio general derivado de la citada cláusula pacta sunt servanda.

De la referida forma, en situaciones verdaderamente excepcionales, a ser analizadas detalladamente en el cuerpo de este trabajo, la doctrina jurídica más avanzada y la jurisprudencia de las últimas décadas, principalmente de los países occidentales, han admitido una revisión de las condiciones de los contratos por fuerza de una intervención judicial, vía de regla invocada por el contratante en situación de desventaja.

Esta posibilidad de intervención judicial en el contrato solamente ocurrirá cuando un elemento sorpresa surja en el curso de la ejecución del mismo, colocando, como consecuencia, en extrema dificultad a uno de los contratantes, o sea, en otras palabras, ocasionando una excesiva onerosidad, por encima del límite razonable de sacrificio, lo que la doctrina tradicional alemana denomina como opfergrenze.

En relación al origen histórico, merced a la fuerte tendencia emanada de la doctrina jurídica más antigua, se suele 
visualizar, en la Edad Media la materialización de esta postura. En esa época, se admitió, con intensidad, la posibilidad de alteración del contrato si las condiciones originarias, sobre las cuales se asentó la voluntad de las partes, fuesen substancialmente modificadas: "contractus qui habent tractum sucessiun et dependetian de futuro rebus suc stantibus intelligentur”. Posteriormente, se difundió la cláusula resumidamente en la expresión jurídica "rebus sic stantibus" ("estando así las cosas”), cláusula considerada implícita en todo contrato de ejecución continuada o de tracto sucesivo.

Adormecida por un significativo espacio de tiempo, debido a contingencias históricas y económicas (como será demostrado en el desarrollo del presente trabajo), la referida cláusula, sin embargo, adquirió gran fuerza y vigor con posterioridad a la Primera Guerra Mundial (1914-1918), en virtud del desequilibrio causado en los contratos a largo plazo, quedando conocida a partir de entonces, y en la actualidad, como Teoría de la Imprevisión.

En realidad, hoy en día, es de gran importancia esta teoría, que tiene en vista, como última interpretación, flexibilizar el principio de la intangibilidad contractual, con el restablecimiento del equilibrio de las prestaciones. Ello, por intermedio de la intervención judicial que tiene por finalidad esencial la revisión del contrato suscripto, o en último caso, no siendo ello posible, su lisa y llana resolución. 
En este sentido, la preocupación mayora que orientó y norteó este trabajo de investigación, fue demostrar la necesidad de la correcta comprensión de la teoría de la imprevisión en la actual fase del moderno Derecho Contractual, que, cada vez más, se aleja del absolutismo dogmático de la cláusula clásica del "pacta sunt servanda”.

La Teoría de la Imprevisión, con todas sus modulaciones doctrinarias, debe reiterarse, es un instituto repleto de dificultades, tanto en la práctica, como en la teoría, especialmente a nivel de doctrina y jurisprudencia.

A todo momento se depara el operador del derecho con serias divergencias en lo que se refiere a su aplicación, contextualización y cabida, en el ambiente tormentoso de las demandas judiciales, con todos los tropiezos y problemas conocidos.

Sin embargo, a pesar de algunos operadores del derecho restringir extremamente los casos de aplicación de la teoría, ella se consolidó como eficaz recurso de protección, de carácter indispensable, a fin de encontrarse un término medio entre las partes contratantes, cuando haya alteración repentina e imprevista de las circunstancias, que deshagan la base del negocio, de modo que sea imposible el cumplimiento de lo anteriormente pactado. 
La historia del derecho le enseña al operador que el siglo XIX, conocido como siglo emergente de las concepciones liberales, representa el resultado de una época en que fueron implementadas las grandes codificaciones del derecho civil. Ello, teniendo en el perímetro de los contratos, como fundamento rector del derecho contractual, el principio de la autonomía de la voluntad.

Esa era de las codificaciones quedó marcada, en el ambiente contractual, como claramente fue expuesto, por la primacía del individualismo, que consagraba el retorno a las reglas clásicas del romanismo, estableciendo (o rescatando, de manera absoluta) el principio "pacta sunt servanda".

La adopción de este principio, se reitera una vez más, fue reforzada por el hecho de que las relaciones económicas en esa época eran razonablemente estables, sin las grandes amenazas de guerras y crisis globales que agitaron todo el siglo $\mathrm{XX}$, y continúan, para gran asombro, en este conflictivo inicio de siglo (el "11 de Septiembre" es un dato concreto y de temer).

No se admitía, así, como regla dogmática, la posibilidad de revisión del contrato, debido a la ocurrencia del nacimiento de circunstancias sobrevinientes a la elaboración del mismo. Sin embargo, a comienzos del siglo XX, como expuesto antes, con estallido de la Primera Guerra Mundial (1914-1918), tuvieron lugar situaciones contractuales insostenibles, especialmente en suelo europeo. 
Las mismas acarrearon una onerosidad excesiva para una de las partes contratantes, ocasionando, también, como consecuencia directa, desequilibrio de vida, fracaso de previsiones en el comercio y actividad empresarial, así como súbitas mutaciones tanto en la economía nacional como internacional.

Así, fue preciso considerar y valorar una variedad de controversias y situaciones, en las que se encontraban individuos, empresas, asociaciones, y segmentos sociales económicamente activos, sorprendidos por las circunstancias extraordinarias e inopinadas y, por ello, reducidos a la imposibilidad o extrema dificultad de cumplir satisfactoriamente con las obligaciones anteriormente asumidas.

Por eso mismo, los juristas de la posguerra, principalmente, preocupados en dar atención a los reclamos de los deudores imposibilitados de ejecutar, satisfactoriamente, los contratos a los que anteriormente se habían obligado, invocaron y perfeccionaron la antigua figura de la cláusula "rebus sic stantibus", ahora llamada, como fue explicado, Teoría de la Imprevisión, actualmente robustecida por los conceptos más amplios y abarcadores derivados de la Teoría de la Base del Negocio Jurídico, que dio oportunidad para el surgimiento posterior en el actual Código Civil Alemán, al denominado "Derecho de la perturbación de las prestaciones." 
En este sentido, a fin de restablecerse la equivalencia de las prestaciones, elemento ínsito en todo contrato, fue concebida la Teoría de la Imprevisión, cuyo fundamento jurídico más integrador es la propia buena fe de los contratantes.

La denominada Teoría de la Imprevisión, por lo tanto, fruto concreto de los principios de buena fe y de la siempre necesaria equidad contractual, encarna, en última instancia, el respeto por la real intención de las partes. Ello, dado que la voluntad de los contratantes, antes que nada, tiene que someterse a las leyes, a los principios generales del Derecho, a las buenas costumbres y, sobretodo, a la buena fe objetiva, entendida como un padrón de conducta basado en la probidad, lealtad y honestidad.

De todo ello deriva la necesaria problemática, a ser enfrentada en este estudio, de los varios aspectos jurídicos (y sus consecuencias relevantes) que gravitan sobre dos puntos. Por un lado, alrededor de la máxima pacta sunt servanda y, por el otro sobre la necesidad de reverse, con un mínimo de criterio y seguridad jurídica, ciertos acuerdos que consagran, en definitiva, una probada onerosidad excesiva, no compatible con la voluntad originaria de las partes contratantes. 
El tema en estudio, por lo tanto, a causa de sus matices y sutilezas, es singularmente instigador y desafiador para el operador del Derecho. De ahí, consecuentemente, la necesidad, en esta posmodernidad, de la búsqueda para vislumbrar respuestas más efectivas a los desafíos diarios propuestos por la "praxis" negocial de los contratos.

En este sentido, a fin de dar con las respuestas necesarias, el presente estudio, que cuenta con seis capítulos ${ }^{1}$, exigirá un enfrentamiento metodológico ecléctico del tema abordado, con base en los siguientes criterios científicos y ejes fundamentales, a saber:

a) Adopción del método deductivo bibliográfico, siempre que se cotejen institutos, normas y formas de derechos expuestos (inclusive cuando se trate de derecho comparado) y su respectiva eficacia. Serán cotejadas las principales teorías existentes, con la debida y necesaria comparación y conciliación (si es posible), teniendo como criterio rector la coherencia, consistencia y la no contradicción;

1 La división de la presente investigación en seis capítulos, más la conclusión, se debe, fundamentalmente, a la intención de ofrecer al lector un texto de contenido científico investigativo, pero paralelamente a ello, que sea de fácil comprensión. 
b) La presente investigación pretende adoptar, como proceso metodológico, la dogmática jurídica, proceso específico de la ciencia del Derecho, basándose en la legislación (derecho positivo), jurisprudencia, derecho consuetudinario y la doctrina correspondiente, especialmente la de Derecho Constitucional, Derecho Civil y Derecho Empresarial (antiguo Derecho Comercial). La dogmática jurídica, como es sabido, deriva, fundamentalmente, de la naturaleza predominantemente imperativa de las normas jurídicas;

c) Análisis del proceso histórico, con el objetivo, sobre todo, de dar la correcta interpretación a los acontecimientos del pasado, remoto y reciente, con el propósito de descubrir referencias seguras que puedan ser útiles para la investigación del tema abordado;

d) Estudio y análisis de casos relevantes, inclusive en un ambiente de derecho comparado, con los desarrollos históricos respectivos, buscando el correspondiente diálogo científico y la interacción y explicación de hechos que producen (o produjeron) cambios significativos. 


\section{CONSIDERACIONES GENERALES SOBRE LOS CONTRATOS}

\subsection{Orígenes remotos del contrato}

\subsection{El contrato como fuente de obligaciones}

Antes de ingresar en el estudio detallado del objeto del presente trabajo, es menester enfrentar algunas cuestiones introductorias, relacionadas con los principales pilares de los contratos en general, a fin de demarcar mejor el perímetro del tema a tratar, teniendo en cuenta, siempre, como telón de fondo, el gran legado del Derecho Romano $^{2}$.

\footnotetext{
2 Merece destacarse desde ahora, para establecer los límites precisos del presente estudio, que el análisis de los contratos se realizará teniendo como referencia la tradición romanista y, consecuentemente, la impactante herencia del Derecho Romano en el Derecho Peninsular Europeo. Por lo tanto, se deja de lado deliberadamente la doctrina obligacional del "Common Law". En el sistema jurídico perteneciente a la familia del Derecho Romano-Germánico, el acuerdo de voluntades, observándose los límites de la ley, es el elemento esencial de validez de los contratos, destinados a establecer, en última instancia, una reglamentación de los intereses de las partes. Difiere, sin embargo, del objetivo esencial de una relación contractual basada en el sistema anglosajón, cuyo punto fundamental es el intercambio (exchange). Ello se justifica por ser el comercio de bienes, servicios y derechos intangibles fundamental para la economía y la sociedad, siendo a la principal función del "contract" facilitar y regular dichos intercambios (exchanges) ( in” BRIAN A. BLUM, "Contracts examples \& explanations", Aspen Publishers New York, 2004).
} 
Ello porque, evidentemente, cuando se habla en la invocación de la llamada teoría de la imprevisión y de sus respectivos desdoblamientos doctrinarios, no deben olvidarse los principios fundamentales que, con el correr de los siglos, fueron considerados y consolidados para dar sustrato jurídico eficaz a los contratos en general, como fuente de obligaciones contractuales, que van de la mano de las denominadas obligaciones legales ${ }^{3}$.

${ }^{3}$ Esta distinción - entre obligaciones contractuales y obligaciones legales - es de fundamental importancia para el análisis de las consecuencias jurídicas sobrevinientes. Según el profesor FÁBIO ULHOA COELHO, de la Universidad Católica de São Paulo, "la existencia y la extensión de una obligación dependen de las disposiciones de derecho positivo o de la voluntad de las personas directamente interesadas. Cuando son las normas jurídicas que definen, totalmente, la existencia y extensión del vínculo obligacional, estamos delante de una obligación legal. En esta categoría, se encuentran los tributos, la cuota alimentaria, la indemnización por acto ilícito dañoso, los beneficios previsionales. Sin embargo, cuando la definición de la existencia o de la extensión de la obligación no se encuentra inserta en su disciplina legal, reservándose a la voluntad de las personas directamente involucradas en la relación la facultad de participar de esta definición, tenemos frente a nosotros una categoría diversa de la obligación. En este segundo conjunto de vínculos obligacionales, se halla el contrato, al lado de las obligaciones de carácter institucional (casamiento, constitución de sociedad por acciones, institución de fundación, etc.). Estos dos tipos de obligaciones (contractuales e institucionales) se diferencian por el régimen jurídico de su constitución y disolución" (UlHOA COELHO, F., "Manual de Derecho Comercial”, 15 edición, Saraiva, 2004, p. 420). 
Siguiendo esta línea de razonamiento, es obvia y se encuentra fuera de controversias la contribución del Derecho Romano, en las principales ramas del Derecho contemporáneo. Los casi mil años de evolución y perfeccionamiento, galvanizados en sus principales períodos, básicamente entre el año 753 A.C. y el 565 de la era cristiana (arcaico, clásico, preclásico y Justiniano), comenzando por la Ley de las Doce Tablas (Lex Duodecim Tabularum), hasta el mencionado período Justiniano (Corpus Iuris Civillis), representaron - y aún representan - una fantástica evolución de la ciencia del Derecho, cuyos pilares se encuentran , actualmente, en los ordenamientos positivos de los principales países de Europa continental y América Latina, que bebieron de esa inagotable fuente de tradición romanista.

Obligación, etimológicamente, deriva del latín "obrigatione" y traduce la idea de un deber o compromiso ${ }^{4}$. Según el jurisconsulto romano Gaio, en consonancia con sus famosas Institutas, la obligación deriva del contrato o del delito. Posteriormente, en la época de otro notable jurisconsulto (Justiniano), se instituyeron otras fuentes generadoras de obligaciones, denominadas "cuasicontrato" y "cuasidelito".

\footnotetext{
${ }^{4}$ Sobre el concepto y elementos fundamentales de las obligaciones, el jurisconsulto brasileño WALDIRIO BULGARELLI sustenta que el término "obligación, y también derecho de las obligaciones puede ser entendido en varios sentidos; aún en sentido técnico, las definiciones varían de un autor a otro. Substancialmente, sin embargo, la obligación es el vínculo en razón del cual, alguien, como sujeto pasivo, está obligado a cumplir una prestación de dar, hacer o no hacer alguna cosa, en favor de otro - sujeto activo" (BULGARELLI, W., “Contratos Mercantis”, Atlas, pp. 24-25).
} 
El eminente doctrinario brasileño SILVIO RODRIGUES ${ }^{5}$, intentando explicar cada una de esas fuentes, entiende que el contrato es fuente de obligación entre las partes porque se establece vínculo entre los contratantes. De esta manera, quedan comprometidos entre sí a realizar una determinada prestación.

El delito, a su vez, viene también a ser fuente porque aquél que, de forma intencional, causa un daño a otro debe inmediatamente repararlo. Por su parte, el cuasicontrato surge de los actos humanos errados, con índole de ilicitud, que no se fundamentan en cualquier acuerdo de voluntades. Finalmente, el denominado cuasidelito surge en los casos en que no se tiene la intención de causar daño. Sin embargo, en virtud de eventual imprudencia o negligencia, por causa de la conducta culposa, sin dolo, sobreviniendo la existencia de eventual daño, éste, debe también ser reparado.

Esta fórmula, derivada del Derecho Romano, fue denominada por la esmerada doctrina como cuadripartita. Ésta fue acogida por ROBERT POTHIER para la confección del célebre Código de Napoleón, en Francia, a comienzos del siglo XIX (vigente hasta hoy), y perfeccionada por él mismo con la adición de una fuente más al concepto cuadripartito supra mencionado, la propia ley.

Actualmente, en las legislaciones occidentales más modernas, las fuentes obligacionales fueron adecuadas

\footnotetext{
${ }^{5}$ RODRIGUES, SILVIO, “Curso de Direito Civil”, Saraiva, São Paulo.
} 
en los respectivos ordenamientos jurídicos positivos, tanto en el contrato, con sus variables tipológicas como en la declaración unilateral de voluntad y en el acto ilícito, doloso o culposo. De esta manera, con el objetivo de situar mejor, históricamente, el contrato en el perímetro de las sabias y profundas disposiciones románicas, pasaremos seguidamente, al enfrentamiento de algunos aspectos puntuales relevantes del contrato en la profunda e intensa mirada del Derecho Romano.

\subsection{Orígenes remotos del contrato}

Las formas más primitivas que se conocen de contratos tienen su origen histórico en el denominado Derecho Quiritario, también conocido como Derecho Romano Arcaico. La característica de este período era el exceso de formalismo, oralidad y rigidez, con la adopción de una lógica verdaderamente aritmética.

Llegado este punto, por lo tanto, el análisis de la evolución histórica del Derecho Romano deja patente que, en relación al desarrollo del sistema de contratos, el mismo está íntimamente relacionado con el desarrollo de los derechos obligacionales y con aspectos sociales e históricos de la sociedad de marras, con todas sus estratificaciones sobradamente conocidas. 
La doctrina más tradicional que se dedica al análisis del desarrollo histórico de las obligaciones, siempre sostuvo, con propiedad, que el derecho de las obligaciones era la parte más importante del Derecho Romano, ya que dichos derechos fueron consolidándose, a lo largo de los siglos, en un cada vez más perfecto y uniforme cuerpo doctrinario, extremamente sofisticado.

No hay necesidad de ser un jurista o un operador del derecho, para observar que el orden jurídico, que comenzó a ser diseñado en el Derecho Quiritario, buscaba soluciones concretas y uniformes, conforme las crecientes demandas y transformaciones del clima social entonces existente.

En este orden de ideas, el Derecho Romano puede ser dividido en cuatro grandes bloques. El período del Derecho Quiritario, en el cual, según enseñan ALEXANDRE CORREIA y GAETANO SCIASCIA ${ }^{6}$, el sistema obligacional era ritualmente formalista, con carácter estricto, propio de una sociedad primitiva, que buscaba un cierto grado de organización y civilidad.

Siguiendo a los autores citados, en relación al segundo período, cuando Roma se encontraba en franca

${ }^{6}$ CORREIA, A. y SCIASCIA, G., “Manual de Direito Romano”, Vol. I, Saraiva, São Paulo, 1955. 
expansión, después de las Guerras Púnicas $^{7}$, se impusieron nuevas transformaciones conceptuales, con el objetivo claro de adecuarse a las crecientes exigencias y demandas sociales. En esta fase se manifiesta la acción del ius gentium y del ius honorarium, siendo que durante ese lapso el trabajo de los jurisconsultos fue más intenso y productivo.

En los dos últimos períodos conocidos (período Clásico y período del Bajo Imperio), sobrevinieron nuevas e intensas alteraciones contractuales. Las causas fueron de dos órdenes, primero, debido al creciente perfeccionamiento de los medios existentes de análisis y síntesis, y en segundo lugar, por la creciente necesidad de sistematización de los institutos jurídicos hasta entonces diseñados, que desembocaron en las fusiones del "ius civile, ius gentium e ius honorarium.

Finalmente, en el período del Bajo Imperio, con la alteración de las formas solemnes y la consecuente fusión

\footnotetext{
${ }^{7}$ Conforme los historiadores clásicos, las Guerras Púnicas constituyeron una serie de tres cruentas guerras contra la República de Cartago - actual Libia - por el dominio militar y, sobre todo, comercial, de la región del Mediterráneo occidental, en el período que media entre el 264 a.C. y el año 146 a.C. Después de la victoria romana definitiva, la destrucción total de Cartago y finalizada la tercera guerra, Roma pasó a dominar todo el comercio en el Mediterráneo occidental e inició, seguidamente, un intenso período de guerra progresiva de conquista en el continente europeo, expandiendo, aún más, el imperio. Esta expansión, con el telón de fondo del crecimiento comercial, llevó al surgimiento de nuevas clases sociales en Roma y a la necesidad, por esta causa, de perfeccionar los institutos jurídicos existentes y crear nuevos que se adecuasen al nuevo tiempo.
} 
de los diversos institutos jurídicos, la estructura de las obligaciones fue simplificada, con todo el sistema orientado hacia la nueva corriente, valorizando al máximo de la voluntad de las partes.

De esta forma, merced a la sintética evolución histórica expuesta, se puede observar que el origen de lo respectivo al tema, se encuentra en el mencionado Derecho Quiritario. En ese derecho primitivo, como fue resaltado, la obligación nacía de la mera intervención oral, que se traducía en un contrato verbal por el cual el deudor se vinculaba al acreedor, por intermedio de pregunta y respuesta, con carácter de promesa solemne ${ }^{8}$. Por lo tanto, esa promesa (sponsio) representaba un vínculo de palabra, que una parte contratante hacía a la otra.

En la misma senda, ALEXANDRE CORREIA y GAETANO SCIASCIA $9{ }^{10}$ sostienen, con mucho vigor, que

\footnotetext{
${ }^{8}$ Por ejemplo: "spondesne nihi dare centum? Spondeo”, o sea, “Prometes darme un ciento?" "Sí, prometo" - VILLAÇA DE AZEVEDO, A. "Teoria das Obrigações", 1999, p.272.

9 CORREIA, A. y SCIASCIA, G., “Manual de Direito Romano”, Vol. I, Saraiva, São Paulo, 1955, pp. 283/284.

${ }^{10}$ Los mismos autores, reforzando tales aserciones, aducen que "como todos los actos jurídicos del período quiritario, también los contratos del período arcaico presentan carácter riguroso y sacramental. Esta es una peculiaridad de todos los institutos primitivos, que no conciben actos jurídicos que no sean basados en ritos solemnes,
} 


\section{Alteración de las Circunstancias y Revisión Contractual}

los contratos verbales ("obligationes verbis contractae"), son aquellos que se perfeccionan mediante el decir de determinadas palabras. Ya ha sido visto que, partiendo de esa modalidad de conducta, derivan las obligaciones de naturaleza contractual del derecho quiritario ("nexum" y "sponsio").

Sin embargo, por causa de las crecientes transformaciones sociales ocurridas dentro del Imperio Romano, correspondientes con las nuevas exigencias de la vida cotidiana, y especialmente por las actuaciones de los pretores y magistrados, en el ejercicio de la jurisdicción, las directrices primarias del Derecho Romano, en lo que atañe especialmente a la verbalización de las promesas, cede paso al nacimiento de nuevos institutos contractuales, donde el consenso de las partes pasa a ser la referencia mayor para dar la necesaria eficacia a los contratos en general. ${ }^{11}$

capaces de atestar públicamente la realización. Poco importa que las formas no correspondan a la voluntad de los contratantes; la intención de las partes está materializada en las palabras pronunciadas, que son decisivas. Esta concepción es consonante con el estado primitivo de derecho: la simplicidad de las relaciones que nacen de una sociedad patriarcal. A las formas rigurosas corresponde la odiosa severidad de los institutos de ella derivados: el "nexum", por ejemplo, implica en su "manus iniectio" tremendas consecuencias. Las solemnidades y las formalidades no pudieron sobrevivir con todo su rigor a las guerras púnicas, ya que las relaciones entre "cives" y "peregrini" se hicieron más frecuentes, imponiendo nuevas normas y principios que, desarrollándose a través de la jurisdicción del "practor peregrinus", constituyen un orden que se contrapone nítidamente al del derecho quiritario”.

${ }^{11}$ Según los autores ALEXANDRE CORREIA y GAETANO SCIASCIA, buscando explicar el fuerte impacto de esas transformaciones sociales, "paralelamente, el decline 
Lo que viene a colación, a partir de este cuadro evolutivo fundamental, supra mencionado, es la idea central de que, sociológicamente, el Derecho Romano siempre se norteó por el concepto central y prevalente de que en los contratos, hecha efectiva la promesa, ésta debería prevalecer sin ningún tipo de desvío o flexibilización, hasta porque, tratándose de un período de franca consolidación del derecho, representado, en síntesis, por la migración de una forma de organización social primitiva hacia una forma de organización social más civilizada, no se permitía ninguna posición flexible o calibradora, capaz de inviabilizar ese ideario político.

de las formas solemnes determina el grandioso fenómeno de la fusión de todos los ordenamientos. Dicha fusión, después de Constantino, se opera de modo vertiginoso y caótico. Dada la profunda crisis que afecta a Roma en estos tiempos, el derecho se convierte en dominio de práctica forense que, frente al sinnúmero de normas del "ius civile", del "ius gentium", del "ius honorarium" y del "ius extraordinarium" pode sólo aprovechar las más conformes a sus necesidades contemporáneas. De esta forma, el derecho se unifica y renueva, ya que las normas más complicadas y rigurosas van siendo dejadas de lado, mientras que las más simples y prácticas entran definitivamente en uso, dando lugar a un nuevo derecho. En consecuencia de estas tumultuosas transmutaciones de la historia jurídica romana, en el sector de las obligaciones contractuales las formalidades pierden su eficacia, ya no habiendo distinción entre "negotia stricti iuris" y "negotia bonae fidei", ni entre pactos principales y accesorios. Lo que importa es la "conventio", o sea, el acuerdo de las partes, que se transforma en elemento constitutivo y esencial de todos los actos contractuales. Por lo que, viciada de modo inicial la "conventio", el acto es nulo "ipso iure", aunque hayan sido observadas las formalidades exteriores. En otras palabras, es la hecatombe de todos los principios del derecho quiritario, desde que los "verba" ya no son eficaces sin el efectivo consenso de las partes contratantes" - in autores citados", "Manual de Derecho Romano", Volumen I, São Paulo, Editorial Saraiva, 1995, pp. 275-276). 
La idea central, conforme lo expuesto, sería que el contrato, como una de las diversas fuentes de las obligaciones, representa un medio para la consecución de un fin (un vehículo en el cual los interesados establecerían ciertas obligaciones de carácter contractual, mediante concesiones recíprocas), debidamente tutelado y protegido por el sistema jurídico vigente en el momento. En cierta medida, representa una variante de la idea central de que el derecho existe como medio para un fin ("as a means to an end"), cuyo concepto ha sido lugar común por al menos medio siglo.

\subsection{El Contrato como fuente de obligaciones}

Inicialmente, PESSOA JORGE ${ }^{12}$, ilustre profesor de la Facultad de Derecho de Lisboa, al reflexionar y buscar definir la idea de obligación, nos transmite la enseñanza de que "el derecho de las obligaciones, como su expresión indica, constituye el conjunto de normas jurídicas que regulan las obligaciones; y la obligación consiste, fundamentalmente, en la posición en que se encuentra alguien de deber practicar un acto a favor de otro, a quien asiste el derecho de la práctica de esa acto."

12 PESSOA, J., "Lições de Direito das Obrigações", Edición de la Associação Acadêmica, 1975, p.7 
En opinión del notable doctrinario portugués JOÃO DE MATOS ANTUNES VARELA, "la primera fuente de las obligaciones - primera, no sólo en la sistematización de la ley y por ventura en la sucesión histórica de los hechos, sino también en el orden natural de las cosas y hasta en su importancia práctica - está constituida por los contratos. Se dice contrato o acuerdo vinculante, asentado sobre dos o más declaraciones de voluntad (oferta o propuesta, por un lado; aceptación, por el otro), sustancialmente distintas pero correspondientes, cuyo fin es establecer una reglamentación unitaria de intereses contrapuestos pero, armónicos entre sí."13

Contrato, derivado del latín "contratu", según el entendimiento ya pacificado universalmente, con insignificantes alteraciones, es el acto o efecto de contratar, que representa un acuerdo de voluntades, sin ningún vicio del consentimiento, derivado de dos o más personas, con la finalidad, pasible de sufrir tutela jurídica, de adquirir, resguardar, modificar o extinguir derechos.

En la célebre y siempre repetida lección del maestro francés ROBERT POTHIER, "un contrato es una especie de convención. Para saber, entonces, qué es un contrato, antes es necesario saber que es una convención. Una convención o un pacto, puesto que estos términos son sinónimos, es el consentimiento de dos o más personas para

${ }^{13}$ ANTUNES VARELA, J., "Das Obrigações em geral”, Vol. I, 2a edición, Livraria Almedina. 
formar entre sí algún compromiso, o para resolver uno existente, o para modificarlo." 14

PESSOA JORGE ${ }^{15}$, citado supra, reflexionando específicamente sobre el tema, sostiene que "el contrato es un negocio jurídico plurilateral" y representa, por eso mismo, la idea de acuerdo, en la medida en que "el contrato, porque envuelve necesariamente declaraciones de voluntad de más de una persona, exige que entre ellas se establezca un acuerdo: todo contrato es un acuerdo".

En la búsqueda de una definición más actual, LUIZ DIES-PICAZO y ANTONIO GULLÓN preconizan que "en un sentido más restringido, y buscando el sometimiento a un régimen jurídico unitario, la doctrina más reciente aplica el concepto de contrato exclusivamente respecto de todos aquellos negocios jurídicos que inciden sobre relaciones jurídicas patrimoniales. Visto desde esta perspectiva, el contrato es el negocio jurídico patrimonial de carácter bilateral cuyo efecto consiste en constituir, modificar o extinguir una relación jurídica patrimonial." ${ }^{, 16}$.

${ }^{14}$ POTHIER, R., “Tratado das Obrigações”, traducción de Douglas Dias Ferreira y Adrian Sotero Batista, $1^{\text {a }}$ edición, Servanda, 2002, p. 310.

15 PESSOA, J., "Lições de Direito das Obrigações", edición de la Associação Acadêmica, 1976, pp.161 y 163

${ }^{16}$ DIEZ PICAZO y GULLÓN, A., "Sistema de Derecho Civil”, Vol. II, 9 a edición, Tecnos, p. 29. 
En la misma línea de pensamiento, CARLOS LASARTE ALVAREZ sustenta que "el contrato, por ende, es un mecanismo de generación de derechos y obligaciones respecto de las partes, quienes se encuentran vinculadas a la realización de su promesa por el mero hecho de haberse comprometido a ello, por haber prestado su consentimiento. La circunstancia de que el contrato es fundamentalmente un procedimiento de creación de relaciones obligatorias no merece mayor detenimiento" ${ }^{\prime 17}$.

El jurista brasileño, FRAN MARTINS, profesor emérito de la Universidad Federal do Ceará, Brasil, por su parte, define contrato como "el acuerdo de voluntades de dos o más personas, para, entre sí, constituir, regular o extinguir una relación jurídica de naturaleza patrimonial" ${ }^{18}$.

También en la misma línea, otro jurista brasileño que hizo escuela, DE PLÁCIDO E SILVA, conceptúa contrato como un "ajuste, convención, pacto o transacción. De ello surge, por lo tanto, la idea de un acuerdo entre dos o más voluntades, para un fin

${ }^{17}$ LASARTE ÁLVAREZ, C., "Manual sobre protección de consumidores y usuários”, Dykinson, 2003. p. 80.

18 MARTIN, F., “Contratos e obrigações comerciais”, 14 edición, Forense, p. 62. 
cualquiera. Resulta, entonces, de la contracción, reunión o agrupación de voluntades" $"$.

Se verifica, por lo tanto, como afirmado anteriormente, que la definición de contrato, no obstante ciertas divergencias doctrinarias conceptuales, en esencia, acaba representando aquello que MANUEL GARCIA AMIGO ${ }^{20}$, ilustre catedrático de derecho Civil de la Universidad Complutense de Madrid sostuvo en memorable artículo jurídico: "dos o más declaraciones de voluntad (Ulpiano), fundidas en una sola (Savigny), la cual crea, modifica o extingue (Ulpiano, Savigny, Domat), una relación contractual (obligatoria) y crea también la norma o parte de la norma reguladora (Ulpiano, Domat) de aquella relación jurídica"

Por lo tanto, la referencia mayor, caracterizadora del contrato, es el concurso concomitante de dos voluntades no viciadas. Desde la antigua Roma, el contrato era considerado un acuerdo

19 DE PLÁCIDO E SILVA, "Noções práticas de direito comercial”, atualizado por Waldir Vitral, 14ª edición, Forense, 1998, p. 333.

20 GARCIA AMIGO, M., “Idea del contrato: 50 años después (Consideraciones previas a una definición del contrtato"), artículo incluido en la obra "Estudios de Derecho de Obligaciones - Homenaje al Profesor Mariano Alonso Pérez", Coordinador EUGENIO LLAMAS POMBO, Tomo I, La Ley, Buenos Aires, 2006, p.764. 
de voluntades, entre partes capaces, cercado de ciertas formalidades y solemnidades. La clásica definición de ULPIANO, a pesar de resumida, representa la mejor expresión de este ideario: "est pactio duorum pluriunve in idem placitum consensus", que, en una traducción libre, quiere decir "el mutuo consenso de dos o más personas sobre el mismo objeto".

Como corolario, desde la antigua Roma hasta mediados del siglo pasado, el contrato, con mayor o menor intensidad, derivó de cuatro principios básicos, considerados clásicos, que son los siguientes: la llamada autonomía de la voluntad, el consensualismo, la regla que los pactos firmados deben ser observados y cumplidos, sustentados en la máxima romana "pacta sunt servanda", y la relatividad de sus efectos. ${ }^{21}$

Estos principios conjugados consagran, de sobremanera, el ideario que el contrato es un acto de autonomía privada, contenido en los presupuestos de su reconocida función social y equilibrio del derecho de las partes (equilibrio del propio contrato). En otras palabras, en el derecho clásico, la libertad de contratar, la fuerza obligatoria del contrato y los efectos de éste vinculando apenas a los efectivos contratantes, sin afectar, de forma alguna, la esfera jurídica de terceros, extraños al acuerdo original (principio de la relatividad de los contratos),

\footnotetext{
${ }^{21}$ Ver, al respecto, comunicación por nosotros presentada en el XIV Congreso IberoAmericano de Direito Romano y XI Congreso Internacional de Direito Romano en Lisboa, 2009 - FERNANDES DE ALMEIDA, ROBERTO, “A cláusula pacta sunt servanda e a teoria da imprevisão".
} 
siempre representaron los principales pilares de la llamada teoría clásica de los contratos, vinculada a un modelo liberal e individualista.

Este modelo liberal, derivado de las corrientes de este tipo que sacudieron principalmente a Europa, a partir del siglo XVIII, hizo naturalmente del contrato el más importante de los vínculos jurídicos realizados entre personas capaces. El mismo sujetaba a las partes jurídicamente, como forma de conferir prestigio, para un modelo económico inspirado y calcado en la creciente necesidad de satisfacción de intereses privados e individualistas, con una clara señalización de que el Estado, salvo rarísimas excepciones (siempre disciplinadas y con resguardo en el derecho respectivo) no debería entrometerse en las cuestiones entre particulares.

Es un hecho que, con la llamada Revolución Industrial $^{22}$, a mediados del siglo XIX, comenzó una cierta tendencia limitadora de la libertad de contratar, derivada de la fuerte interferencia del Estado en ciertos casos, merced a determinados tipos de relaciones contractuales. Esta tendencia fue denominada como dirigismo contractual, intentando impedir, a final de cuentas, ciertos abusos en algunas modalidades de contrato, donde una de las partes, sabidamente, ya

${ }^{22}$ Conforme los principales historiadores, la "Revolución Industrial" personificó un intenso y grande conjunto de cambios tecnológicos en el llmado mundo ocidental, a fines del siglo XVIII y en buena parte del XIX, teniendo (en un primer momento) a Inglaterra como su principal exponente. 
se presenta, al momento de la contratación, en situación de nítida desventaja, casi siempre de cuño económico.

La doctrina asentada en la citada expresión 'dirigismo contractual' fue consolidada, científicamente, por el excelso jurista francés LOUIS JOSSERAND, a fines de la década del veinte del siglo pasado ${ }^{23}$. En la base de esta doctrina se encuentra la creciente noción de búsqueda de justicia social, con el fin de evitar (o buscar evitar) la práctica de ciertos abusos, en la esfera de la "lex privada" (el propio contrato) del económicamente más fuerte en la relación contractual entre particulares.

La doctrina concebida por LOUIS JOSSERAND, por cierto, está plasmada con la idea concebida por el sociólogo inglés THOMAS MARSHALL ${ }^{25}$, en el sentido de que los derechos básicos, que componen la ciudadanía, fueron naciendo y

${ }^{23}$ JOSSERAND, L., "Derecho civil: teoria general de las obligacioens". Traducción de Santiago Cunchillos y Manterola, Bosch, Buenos Aires, 1950.

${ }^{24}$ JOSSERAND, L., “Tendences actuelles da Théorie dés Contracts”. RT, 1937, p. 21 y ssgtes. Ver, también al respecto BOBBIO, NORBERTO, "A Era dos Direitos", traducción de Carlos Nelson Coutinho, Campus, Río de Janeiro, 1992.

${ }^{25}$ MARSHAL, T., “Cidadania, classes sociais e status”, Zahar, Río de Janeiro, 1967. 
afirmándose a lo largo de los tres últimos siglos, a saber: los derechos civiles en el siglo XVIII, los derechos políticos en el siglo XIX y los derechos sociales en el siglo XX.

En otras palabras, el fundamento de esta doctrina consagra una técnica destinada a mejorar la protección de los intereses del elemento económicamente más débil, restringiendo la libertad individual / contractual del elemento económicamente más fuerte, especialmente en lo que se refiere a la discusión del contenido del negocio a ser entablado. Además, esta tendencia, presente en el derecho de los contratos contemporáneo, fue bien detectada por el ya citado jurista portugués JOÃO DE MATOS ANTUNES VARELA. ${ }^{26}$

\footnotetext{
${ }^{26}$ Hay muchos autores que afirman que la importancia del contrato tiende a declinar en la vida económico-jurídica de las sociedades modernas, a medida que la autoridad de la ley, basada en exigencias superiores de justicia, de equidad y de seguridad social, va restringiendo cada vez más la esfera de actuación de las libertades individuales. La afirmación parte de un hecho incontestable, pero expresa un diagnóstico que necesita corrección. La evolución de la vida económica (primero con la revolución industrial, después con la revolución tecnológica), la proliferación de las relaciones contractuales estereotipadas o de masa y la propia modificación de las concepciones morales, políticas y sociales reinantes en la colectividad destruyeron algunas ideas-maestras en las cuales se asentaba el liberalismo económico (como ser, la igualdad de los contratantes y el principio del equilibrio espontáneo como efectos sistemáticos del juego de la libre competencia, y la creencia ingenua pregonada por ADAM SMITH de que las leyes de mercado y el egoísmo individual son los mejores instrumentos para la felicidad y la prosperidad de las naciones) y provocaron una acentuada intervención del Estado en la disciplina de muchos contratos, con el objetivo de eliminar los graves inconvenientes derivados de la libertad incontrolada de las partes" (ANTUNES VARELA, J.M., “Das obrigações em geral”, Vol. I, $2^{\text {a }}$ edición, Livraria Almedina).
} 
El ejemplo más común es el contrato de trabajo, donde, en la mayoría de las legislaciones de los países occidentales, existen expresas disposiciones que limitan la autonomía privada, con el concreto objetivo de proteger al llamado contratante débil o hipo suficiente (en este caso, el empleado, la parte económicamente en desventaja). En el derecho brasileño, verbi gratia, la legislación laboral flexibiliza las disposiciones contractuales firmadas entre empleado y empleador.

Aunque el empleado, al momento de la contratación por el empleador, en el respectivo contrato de trabajo, venga, por ejemplo, a renunciar a algún derecho consagrado en la legislación laboral positiva (derecho a vacaciones, paga extra, etc.) este acto de disposición, habiendo discusión en juicio, no será tomado en consideración por el juez, que fallará, desconsiderando la postura anteriormente asumida por el trabajador.

Este dirigismo contractual ganó espacio creciente a inicios del siglo pasado, sembrando las primeras semillas de la reconstrucción de los pilares que siempre fueron la base del negocio jurídico teniendo como telón de fondo al modelo liberal. En realidad, esta conducta terminó cuestionando el primer nivel evolutivo del derecho de los 
contratos, sustentado, fundamentalmente, como ya se dijo en el concepto de "pacta sunt servanda".

Debe enfatizarse, por ser de vital importancia, que tal dirigismo contractual no es encontrado solamente en el derecho laboral. Modernamente, y principalmente a partir de mediados del siglo pasado, también es fácilmente localizado en las reglas que disciplinan y tutelan las relaciones de consumo (derecho del consumidor) e inquilinato (alquiler de inmuebles). En estos ámbitos son encontradas y localizadas varias disposiciones legales que limitan y hasta dificultan la autonomía privada, sea con prohibiciones expresas, representadas por normas de cumplimiento obligatorio para las partes, que inhiben y obstaculizan la inserción de ciertas cláusulas y condiciones en los contratos que involucran relación de consumo o de locación ${ }^{27}$, imponiendo a los contratantes obligaciones no creadas originariamente por ellos.

También aquí, de manera concreta, tenemos la efectiva intervención estatal, vía normas de cumplimiento obligatorio (que no admiten convención en sentido contrario), que limitan, efectivamente, la libertad de contratar, siempre buscando la protección del contratante consumidor, persona física o jurídica, en acuerdos que envuelven relación de consumo o locación de inmuebles, considerando su

27 En líneas generales, como expresado supra, el dirigismo contractual cristaliza la intervención directa, cada vez con más intensidad, por parte del Estado en la actividad individual de los sometidos a la jurisdicción, específicamente, en la propia autonomía privada. Las relaciones de consumo y laborales representan, reiterando lo expuesto, un vivo ejemplo de esa ideología jurídica. 
gran impacto social, hecho de por sí, verificable a simple vista y por el sentido común.

A este respecto, algunos juristas, inclusive, sustentan, que en realidad en la evolución del Derecho de las Obligaciones, pero especialmente en el derecho inherente a los contratos, nunca existió una efectiva e ilimitada libertad para contratar; apenas una flexibilización, con mayor o menor intensidad, dependiendo del momento histórico respectivo y de la normativización de los contratos. FÁBIO ULHOA COELHO, en relación a esto argumenta que "siempre hubo una determinada disciplina normativa de los contratos. En la Antigüedad Clásica, el derecho romano reconocía validez a los contratos reales que hubieran sido contraídos con la observancia de un ritual realizado con el uso de una balanza. En la Edad Media, los instrumentos de ciertos tipos de contrato debían contener el sello de una autoridad feudal”.

Continuando, señala el citado jurista que "hasta en el capitalismo competitivo, contrariamente a lo que solía decir el liberalismo clásico, nunca existió una absoluta libertad de contratar, habiendo el Estado disciplinado normativamente el contrato desde el inicio. Es cierto que esta disciplina ha crecido progresivamente, todavía más en el capitalismo monopólico. Por ello, no sólo el Estado cada vez más define previamente el contenido de determinadas cláusulas contractuales, sino que, a veces, hace obligatorio el contrato o establece precios, condiciones de pago, etc. A título de ejemplo, pueden ser invocados los 
contratos bancarios, que no pueden ignorar un extraordinario conjunto de reglas fijadas por las autoridades monetarias." 28

En esta línea de razonamiento, tenemos las enseñanzas contemporáneas de JOÃO DE MATOS ANTUNES VARELA, que señala “(...) nótese, sin embargo, que la voluntad individual y la ley intervinieron desde siempre, conjuntamente, en la reglamentación de las relaciones contractuales y que, siendo incuestionable el aumento de las limitaciones impuestas a la voluntad de los contratantes, bien como la distorsión del papel de la voluntad de los mismos operada en los contratos de adhesión, también es incontestable la aparición frecuente de nuevos tipos de contratos y de nuevas cláusulas negociales creadas por la libre iniciativa de los interesados (sobre todo de las empresas). Si las exigencias sociales estimulan la intervención de los poderes públicos, también es cierto que los progresos de la técnica y de la imaginación inagotable del hombre estimulan el ingenio de los contratantes. El resultado práctico de la confluencia de estos factores es que no hay propiamente, en los países de economía capitalista, ni en los Estados de sistema intervencionista, una declinación del contrato, sino un aumento de su dimensión social." ${ }^{29}$

${ }^{28}$ ULHOA COELHO, F., "Manual de direito comercial”, 15 a edición, Saraiva, São Paulo, 2004, p. 421.

${ }^{29}$ ANTUNES VARELA, J.M “Das Obrigações em geral”, Vol. I, 2 a edición, Livraria Almedina. 
Este ideario ha dado pie al surgimiento de decisiones judiciales que atemperan los rígidos postulados del principio "pacta sunt servanda", como, por ejemplo, ya fuera proclamado por la Corte brasileña anteriormente denominada II Tribunal de Alçada Civil de São Paulo (hoy Tribunal de Justiça de São Paulo), que, en un caso concreto, estableció que "los principios de la autonomía de la voluntad y de la obligatoriedad de las convenciones sufren limitaciones impuestas por la idea de orden público, entre cuyas normas se encuentran las leyes del inquilinato. $^{30}$

De ahí, en resumen, es lícito afirmar que la llamada Teoría de la Imprevisión, objeto de este estudio, se sitúa en este perímetro intervencionista. Ello, al permitir la modulación de la voluntad originaria de las partes, bajo ciertas condiciones, atemperando y calibrando, con matices singulares y con una disciplina jurídica propia, en la hipótesis de nacimiento de ulteriores situaciones no vislumbradas por las partes al momento del nacimiento del pacto (a ser tratadas más adelante), y sobre las relaciones contractuales anteriormente suscriptas.

Así, para que la prestación, asumida por uno de los contratantes, en un determinado contrato, no venga a tornarse, algunas veces, exorbitante, al punto de llevar a la ruina económica a la otra parte (hecho, casi siempre, informador de un enriquecimiento sin causa del primero), delante de un acontecimiento considerado extraordinario e imprevisible, es que fue elevada y considerada la cláusula "rebus sic

30 Tribunal de Justiça do Estado de São Paulo, apelação cível n ${ }^{\circ}$. 280.300-1, Relator Magistrado Dr. GILDO DOS SANTOS. 
stantibus" (en traducción libre, "estando así las cosas"), actualmente denominada Teoría de la Imprevisión.

Se trata, en realidad, en última instancia, de la flexibilización del principio de la intangibilidad contractual $^{31}$, con el objetivo de rescatar y mantener el equilibrio de las prestaciones asumidas por las partes contratantes, por medio de una efectiva intervención judicial, vía acción correspondiente, manejada por el interesado (o sea, el propio contratante virtualmente perjudicado con la nueva situación fáctica surgida), en el caso que, evidentemente, las partes no logren la calibración y ajuste del contrato de forma amigable, en la esfera extrajudicial.

En este contexto, para que se puedan entender mejor los matices de este trabajo, serán analizados, seguidamente, los principios ya expuestos, en tópicos diferentes, para que en la secuencia pueda ser contextualizado y observado en detalle, y de manera eficaz, el tema propuesto.

31 Que representa, como regla general de la vida de los contratos, conforme la interpretación autorizada de ULHOA COELHO, ser imposible la alteración unilateral de las condiciones, plazos y demás cláusulas contractuales - Obra citada, p. 425 


\section{LA CONSTITUCIÓN DEL VÍNCULO CONTRACTUAL,} AUTONOMÍA DE LA VOLUNTAD Y CONSENSO DE LAS PARTES

Como es meridianamente claro, la voluntad humana es el principal elemento, el principal eslabón, el motor, que engendra el nacimiento de una obligación lícita. Esa voluntad del hombre, cuando es regularmente exteriorizada, en un ambiente de acuerdo de voluntades, hace surgir el pacto o convención ("pactio", "pactum" o "conventio", expresiones heredadas del Derecho Justiniano).

\section{Dice JOÃO DE MATOS ANTUNES}

VARELA, "el cotejo de este concepto, que se extrae de los preceptos de la ley vigente, con la noción de contractus recogida en las fuentes del derecho romano clásico, muestra que hubo en la materia una profunda evolución. Por un lado, el concepto se restringió: mientras los jurisconsultos romanos englobaban en la designación de contractus todos los actos voluntarios generadores de una obligación, fuera un acto bilateral, o unilateral, la doctrina y las legislaciones modernas consideran como esencial al contrato el acuerdo bilateral (o mutuo consenso: el duorum vel plurium consensus) de los contratantes. Por otro lado, se registró una notable ampliación: los romanos limitaban el contractus a los actos destinados a constituir una obligatio (ad constituendum obligationem), al paso que los códigos modernos extendieron el contenido posible del acuerdo contractual a otros 
aspectos de la relación obligacional y a otras clases de relaciones jurídicas." 32

En otras palabras, desde la grandiosa época del Derecho Romano, cuando determinado individuo, sin cualquier vicio de la voluntad y por su propia determinación, quería vincularse, en términos de obligación, frente a otro individuo, hasta los días actuales, tiene el derecho reconocido a eficacia jurídica de tal libre y consciente manifestación. Para ello, disponen los interesados un aparato jurídico capaz de viabilizar la plena realización e implementación de la voluntad anteriormente manifestada, dentro del proceso evolutivo del derecho de los contratos supra preconizado por ANTUNES VARELA.

Como consecuencia directa del libre ejercicio de la voluntad, se estableció, a través de los siglos, una antigua directriz emanada de la concepción clásica de la máxima jurídica "pacta sunt servanda" que, en una traducción libre, quiere decir que "los contratos deben ser cumplidos", puesto que en última instancia son ley para las partes ("lex" privada). De esta forma, citando el fundamento de la autoridad de CARNELUTTI, observamos que "la voluntad es

\footnotetext{
${ }^{32}$ ANTUNES VARELA, J.M., “Das obrigações em geral”, Vol. I, $2^{\text {a }}$ edición, Livraria Almedina.
} 
verdaderamente la materia prima del derecho; y no hay otra, más noble, ni más misteriosa."33.

No fue por otra razón que JORGE A. MAYO afirmó que, "indudablemente, y no tengo dudas, que el principio de la autonomía de la voluntad, aun cuando pueda ofrecer reparos, significa, en última instancia, desde el plano filosófico, el reconocimiento concreto de la libertad de la persona en el ámbito de sus relaciones negociales. Por ello no puede ni debe suprimírselo en esa perspectiva" ${ }^{34}$

Dicho de otra forma, "la idea de autonomía de la voluntad está estrechamente ligada a la idea de una voluntad libre, dirigida por el propio individuo sin influencias externas imperativas. La libertad contractual significa, entonces, la libertad de contratar o de abstenerse de contratar, libertad de escoger su contraparte contractual, de fijar el contenido y los límites de las obligaciones que

33 CARnElUTTI, F., “Metodologia do Direito”, tradução de Frederico A. Paschoal,. Bookseller, Campinas, 2002, p. 38. Véase también, JAN SCHAPP, “Derecho Civil y Filosofia del Derecho - La liberdad en el Derecho" - Universidad Externado de Colombia, Bogotá, 1998, pp. 73 a 74.

34 MAYO, J., "Estudios de Derecho Civil - parte general - Obligaciones, Responsabilidad Civil-Contratos”, La ley, Buenos Aires, 2005, p. 119 
quiere asumir, libertad de poder expresar su voluntad en la forma deseada, contando siempre con la protección del derecho",35

Por lo tanto, en resumen, podemos decir que la libertad para contratar (que hasta puede ser considerado un derecho individual, de estatura constitucional, con inspiración en el propio Derecho Natural), es el verdadero cimiento que da el necesario soporte lícito a cualquier pacto, de cualquier naturaleza, que venga a ser firmado.

\section{LA FUERZA OBLIGATORIA DEL CONTRATO}

Establecida la premisa mayor que cualquier individuo, en el uso y goce de sus derechos, tiene libertad plena para contratar, esto es, para vincularse jurídica y válidamente a otro, mediante declaración, no viciada, de voluntad, es evidente que, habiendo optado por el vínculo, debe el contratante honrar integralmente lo pactado, implementando satisfactoriamente la obligación libremente asumida, con el consecuente derecho de exigir del otro contratante la prestación contractualmente prometida.

Esta regla general, consolidada en la ya mentada cláusula "pacta sunt servanda", consagra la idea de que nadie puede liberarse, por su exclusivo arbitrio, de forma unilateral e por su

\footnotetext{
${ }^{35}$ MARQUES, C., "Contratos no código de Defesa do Consumidor”, Revista dos Tribunais, São Paulo, 1998, p. 45
} 
propia voluntad, de una obligación asumida válidamente. Traduce, en síntesis, la idea de seguridad jurídica, que siempre debe estar presente en los contratos en general, sobre la cual debe reposar la voluntad de las partes, exteriorizada de forma lícita.

En rigor, no podría ser de otra forma: si el vínculo original nació de un libre y consensual acuerdo de voluntades (el llamado principio del consensualismo) tal vínculo, evidentemente, solamente podrá ser deshecho por el deseo (voluntad) de todas las personas involucradas en su creación.

Vale decir, por lo tanto, que los contratos, como consecuencia directa de tal ilación, de una manera general, albergan, de forma explícita o implícita, las cláusulas de irrectratactabilidad y de intangibilidad. En relación a lo dicho, obsérvese la lección de FÁBIO ULHOA COELHO. ${ }^{36}$

Esas dos cláusulas consagran, por orden, la imposibilidad de cesación total del vínculo por mera voluntad

\footnotetext{
${ }^{36}$ Si el vínculo nació de un encuentro de voluntades, solamente podrá ser deshecho por deseo de todas las personas involucradas en su constitución (salvo las hipótesis de desconsitución por factores externos a la manifestación volitiva). Esto significa, específicamente, que todos los contratos tienen, implícitas, las cláusulas de irrectractabilidad y de intangibilidad. (ULHOA COELHO, F., "Manual de Direito Comercial”, $15^{\text {a }}$ edición, Saraiva, São Paulo, p. 417)
} 
(arbitrio) de uno de los contratantes y, también, como ya fue visto anteriormente, la imposibilidad unilateral de alteración de las condiciones y demás cláusulas pactadas. Dicho de otra forma, nadie puede, por su exclusivo arbitrio, desvincularse de un contrato, o, tampoco (de forma unilateral y arbitraria), alterar cláusulas o condiciones existentes en el pacto original.

Es importante resaltar, que los contratos, al derivar de un libre encuentro de voluntades exteriorizado por ciertas personas capaces (contratantes), identificables en los pactos respectivos, solamente generan efectos jurídicos para las partes por él vinculadas (principio de la relatividad, sustentado en la máxima "res inter alios acta, aliis neque nocet neque prodest", o sea, los efectos producidos por un contrato impactan exclusivamente entre las partes, no aprovechando ni perjudicando a terceros), no creando, como regla general, deberes o derechos para personas extrañas a la relación contractual originaria. ${ }^{37}$

Es en este amplio mosaico, por lo tanto, que se considera que el contrato regular, cuando constituido sin vicios de la voluntad, es ley entre las partes (la llamada "lex privada”). Así, “(...) por lo tanto, los tribunales de justicia, en su caso, están para reconocer y hacer

\footnotetext{
${ }^{37}$ Existen, evidentemente, algunas excepciones que justifican esa regla general, como, "verbi gratia", el contrato de seguro de vida o la estipulación a favor de tercero. Sin embargo, por ser excepciones a la regla general, no serán puntos trabajados aquí con profundidad.
} 
cumplir los actos voluntarios lícitos de las personas. Es de competencia del juzgador interpretar las declaraciones de voluntad contenidas en los textos legales; atribuciones que, por cierto, excluyen el poder o facultad de revisión. La ley, como el contrato, son inmutables."38.

Además, debe siempre observarse que tal entendimiento, en su interpretación final, es herencia de algunos sistemas jurídicos occidentales, que bebieron, sabiamente, de la fuente del Derecho Romano y, posteriormente, del Derecho Europeo Continental del siglo XVIII, especialmente del Código Civil Francés que, de forma perentoria, en su artículo 1134, proclama que las convenciones legalmente formadas constituyen leyes para aquellos que las celebran. ${ }^{39}$

En conclusión, como fue visto hasta aquí, el principio de autonomía de la voluntad, piedra basilar de todo y cualquier contrato, informa el poder que ostentan los contratantes de negociar y de pactar libremente, mediante acuerdo de voluntades, sus intereses específicos, que engloban, obviamente, el derecho y la libertad de

${ }^{38}$ FERREYRA, E., "Principales efectos de la contratación civil”, Depalma, Buenos Aires, 1978, p. 33.

39 Artículo 1134 del Código Civil Francés: "Les conventions légalement formées tiennent lieu de loi à ceux qui les out faites. Elles ne peuvent être révogués que de leur consentement mutuel, ou pour les causes que loi autorise. Elles doivente etre exécutées de bonne fos". 
contratar o dejar de hacerlo con autonomía para establecer las condiciones y el respectivo contenido del contrato.

Al referido principio de la autonomía se le galvaniza el principio del consensualismo, como visto anteriormente, que traduce el simple acuerdo de dos o más voluntades, de forma que genera un contrato válido y eficaz, siempre teniendo en cuenta que algunos negocios jurídicos bilaterales condicionan su validez a la observancia de ciertas formalidades. ${ }^{40}$

A partir del momento en que las partes, de forma autónoma y consensual, se vinculan por un contrato, surge, como corolario, el principio de la obligatoriedad de aquello que fue pactado, y que representa la imposición de que las condiciones y cláusulas, albergadas en el documento, deberán ser fielmente cumplidas, bajo pena del contratante incumplidor responder, directamente, por su acto mediante acciones específicas incoadas por el contratante perjudicado.

Por ello es que la doctrina más esmerada considera el acto de contratar como norma jurídica de carácter particular y que, por eso mismo, es ley entre las partes, con concreta y efectiva obligatoriedad, exceptuándose naturalmente, situaciones de caso fortuito o fuerza mayor $\mathrm{y}$, obviamente, onerosidad excesiva en el

\footnotetext{
${ }^{40}$ Por ejemplo, la eficacia y validez de ciertos actos jurídicos están condicionadas a la plena publicidad del acto, mediante el labrado de escritura pública, en la correspondiente notaría.
} 
cumplimiento de la prestación y del propio contrato (situaciones esas que representan, puntualmente, como fue expresado anteriormente, el específico y singular objeto de la presente investigación).

Debe recordarse, que el contrato suscripto vincula solamente a los contratantes respectivos, no pudiendo, como visto, perjudicar a terceros que no estén envueltos, directa o indirectamente, en el acuerdo respectivo, lo que se denomina principio de la relatividad de los efectos del contrato. Como expresa la Profesora MARIA HELENA DINIZ, "por ese principio, el acuerdo apenas vincula a las partes que en él intervinieron, no aprovechando ni perjudicando terceros, salvo raras excepciones". ${ }^{41}$

Estos verdaderos y antiguos idearios jurídicos, con las excepciones y resguardos anteriormente señalados, representan, todavía hoy, la base actual de la Teoría de los Contratos en general.

${ }^{41}$ DINIZ, M.H., “Curso de Direito Civil Brasileiro - Teoria das obrigações contratuais e extracontratuais”, 26ª edición, Saraiva, São Paulo, 2009. 


\section{BREVE MIRADA HISTÓRICA SOBRE LA EVOLUCIÓN DE LOS CONTRATOS, BAJO LA ÓPTICA DE LA PROGRESIVA EXPANSIÓN ECONÓMICA Y LA PRÁCTICA DE ACTOS EN GRAN ESCALA: ANTIGÜEDAD, EDAD MEDIA, MODERNIDAD Y POSMODERNIDAD}

Cuando se trata del tema de la evolución de los contratos, especialmente bajo la óptica de la progresiva expansión económica y práctica de actos en gran escala, de contenido económico, debe considerarse como telón de fondo, por obvio que parezca, como mencionado anteriormente, el derecho obligacional, que, en su conjunto, establece, en última instancia un caudal de reglas jurídicas representativas de las operaciones económicas en general.

Por ello es que, conforme doctrina pacífica, el derecho de las obligaciones se presenta en una rama general, informadora de la Teoría General de las Obligaciones, y con tres ramas específicas, a saber: Derecho de los Contratos, Derecho de la Responsabilidad y Derecho Restitutorio.

En lo que interesa más en vista del presente estudio el Derecho de los Contratos pasa a asumir una relevancia mayor, para entender su progresiva función social, concepto que no puede ser disociado del estudio de los contratos propiamente dichos, y que hace necesario un análisis de la evolución histórica - aunque más no sea en 
términos generales y resumidos - del propio contrato, con ese específico enfoque social, como matriz para la implementación saludable de las necesarias operaciones económicas en gran escala, de cualquier naturaleza.

En dicho sentido podemos decir que en la Antigüedad, el contrato no poseía los valores económicos de gran escala que tiene contemporáneamente, y se encuentran en la gran mayoría de los pactos contractuales de hoy en día, especialmente porque en el antiguo derecho romano la materia contractual permanecía, casi siempre, adscripta a los intereses y litigios de naturaleza privada.

Las distinciones relativas a los contratos, referidas anteriormente a partir de los conceptos de contrato propiamente dicho y cuasicontrato, tomaron forma con la creciente evolución del derecho romano. Sin embargo, en casi ochocientos años de intenso perfeccionamiento, desde la Ley de las Doce Tablas hasta los conceptos más sofisticados de JUSTINIANO, no se dio, por razones sistémicas, una notoria expansión y/o masificación de los contratos, que tuviera efecto de regulación y calibración de las relaciones económicas en gran escala, a fin de, en última instancia, entender al contrato como un vehículo de pacificación social masiva, como ocurrirá a posteriori.

Durante el Imperio Romano, como fue expresado antes, las actividades denominadas comerciales (y que sirven, obviamente, de base para la consecución de las obligaciones a nivel masivo), eran relegadas a un plano notoriamente secundario, ya que la elite 
romana no se dedicaba a tales menesteres, que quedaban a cargo, según THOMAS MARKY ${ }^{42}$, de los esclavos libertos y de los extranjeros ("peregrins"). Se trataba en realidad, por así decirlo, de un auténtico derecho secundario en la exacta medida y proporción en que la aplicación del derecho relacionado con las actividades comerciales era, inclusive, implementada por los pretores y no por los magistrados de la época.

En tal contexto, las relaciones obligacionales, derivadas de los contratos no cumplidos, o deficientemente cumplidos, eran decididas por los magistrados dentro de un abanico restricto de las modalidades por entonces existentes de contratos. Éstas, traducían, desde nuestro punto de vista, la expresada visión elitista de las clases dominantes. Por ejemplo, en esa época, las modalidades más comunes de contratos eran los denominados contratos consensuales ("verbi gratia", compraventa), reales ("verbi gratia", comodato) verbales ("verbi gratia", promesa de dote) y, finalmente, los literales ("verbi gratia", mutuo).

Por lo tanto, el real alcance de los contratos en dicho período se restringía, fundamentalmente, a la tutela de las relaciones obligacionales de naturaleza privada individualista, sin carácter masivo, y de los que gravitan a su alrededor, siendo de escasa importancia para las relaciones económicas y sociales de gran escala, ello

\footnotetext{
${ }^{42}$ MARKY, T., “Curso elementar de direito romano”, Saraiva, São Paulo, 1995.
} 
hasta porque el sistema social romano albergaba una estratificación social intensa y singular.

Sin embargo, en la Edad Media, con el fin y la destrucción del Imperio Romano (y, consecuentemente, del propio Derecho Romano, que permaneció sabidamente adormecido hasta la intervención puntal, siglos a posteriori, de los llamados glosadores), se da el surgimiento, en el viejo continente, de un nuevo segmento social. El mismo proviene de una nueva clase en ascensión representada, fundamentalmente, por los mercaderes, pequeños comerciantes y artesanos, que se dedicaban intensa y crecientemente a la práctica del comercio.

La mencionada ascensión se dio, sobre todo, por causa del surgimiento, progresivo y paulatino, de un nuevo orden económico en Europa, centrado en el creciente poder de la Iglesia Católica, sobre los feudos y reinos medievales, donde las relaciones y contactos comerciales/mercantiles a nivel masivo tuvieron singular preponderancia para la expansión económica. Especialmente, como expresado, en el viejo continente que, a dicha altura, no se encontraba más trabado por las imposiciones políticas, eminentemente centralizadoras, emanadas desde Roma.

Este histórico cambio de rumbo derivó, con el fin del Imperio Romano, de la destrucción de la propia idea central de "Pax Romana", que imponía dentro de los extensos límites del Imperio, la obligatoriedad de sumisión de las relaciones cotidianas a un fuerte e 
intenso control de las elites dominantes, que lograba de esta manera, obtener estabilidad política.

En otras palabras, en la búsqueda de nuevas alternativas económicas sobrevino el surgimiento de una próspera clase social centrada en los pequeños comerciantes y artesanos, con un mayor "status" en las comunidades respectivas, haciendo que, como corolario, se generasen, naturalmente, nuevas normas contractuales para disciplinar las relaciones jurídicas que envolvían, sobre todo, contratos comerciales/mercantiles en amplia escala.

Esta nueva clase social, por causa de la inexistencia de normas contractuales más sofisticadas ${ }^{43}$, que pudiesen atender a una demanda económica cada vez mayor bebieron, inicialmente, de la fuente del derecho consuetudinario (usos y costumbres) $\mathrm{y}$, en secuencia crearon sus propias normas corporativas, destinadas especialmente para la calibración de los contratos de intensa naturaleza económica y, consecuentemente, con mayor impacto social.

${ }^{43}$ En la Edad Antigua, las normas comerciales entonces existentes disciplinaban, casi siempre, conductas comerciales solamente relativas al denominado comercio marítimo, practicado con intensidad por los pueblos del Mediterráneo, especialmente fenicios y cartagineses. 


\section{Dichas normas corporativas $^{44}$ eran}

aplicadas en los tribunales respectivos creados por los propios comerciantes / mercaderes, para la pronta solución de sus litigios, surgiendo, en dicho momento histórico, la conocidísima dicotomía del Derecho Privado, que pasó a albergar dos líneas diferentes, pese a las varias subsecuentes tentativas de unificación (Derecho Civil por un lado y Comercial por el otro, éste último hoy denominado Empresarial, por inspiración del moderno Derecho Italiano). ${ }^{45}$

El fortalecimiento del Derecho

Comercial / Mercantil, actual derecho empresarial - cada vez más disociado y apartado del Derecho Civil - generó la creación de normas obligacionales para ser utilizadas cotidianamente en gran escala,

${ }^{44}$ En la Edad Media, con el nacimiento de una nueva clase social - mercaderes, comerciantes y artesanos - las controversias surgidas, eran decididas por la justicia privada de los propios mercaderes, mediante tribunales corporativos particulares.

${ }^{45}$ La más conocida y comentada es la tentativa de VIVANTE, a finales del siglo XIX, cuando en el aula magna de la Universidad de Boloña, Italia, sustentó sobre la inmediata necesidad de unificación del derecho privado. Posteriormente, el propio catedrático se retractó - recibiendo, inclusive, duras críticas de la comunidad jurídica de entonces -pasando a sustentar la posición diametralmente opuesta, o sea, la idea de que la convivencia entre las dos ramas del derecho, además de posible, era altamente recomendada, considerando las particularidades - intrínsecas e extrínsecas - de las mismas. 


\section{Alteración de las Circunstancias y Revisión Contractual}

particularmente en el período inicial de su sistematización (mediados del siglo XV), y con carácter científico. ${ }^{46}$

Solamente a partir del siglo XVII, por la conjugación de un sistema político plasmado en la idea de democracia primaria y un sistema económico basado en el mercantilismo, es que se rescató, con un nuevo sesgo, la plenitud del principio de la autonomía de la voluntad como matriz fundamental para la formación de los contratos con gran alcance social, pero, es importante destacar, sin, las modulaciones actualmente existentes. ${ }^{47}$

\footnotetext{
46 Como expresado meridianamente antes, la sistematización científica del derecho comercial se dio, inicialmente, en la Universidad de Boloña, para atender a una demanda creciente de incorporación (en las normas a ser editadas), de nuevas tecnologías jurídicas, debidamente identificadas y diseñadas, lo que derivó, hasta la mitad del siglo XVII, de un dato político-económico incuestionable, asentado en existencia, especialmente en el continente europeo, de estados débiles con sistemas políticos centralizadores (sistemas monárquicos).
}

47 Estas modulaciones, representan, en última instancia, la esmerada y correcta clasificación de los derechos propuesta por NORBERTO BOBBIO. Este renombrado jurista y pensador italiano, sustenta en líneas generales, la existencia de derechos de primera generación, representativos de los derechos que garantizan la libertad individual de los sujetos de derecho; derechos de segunda generación, referentes a los denominados derechos sociales, derivados de las respectivas Cartas Magnas de las naciones democráticas; derechos de tercera generación, representados por los derechos difusos o colectivos (también conocidos como solidarios) y, finalmente, derechos de cuarta generación - aún en estado embrionario - que representan los derechos que gravitan alrededor de las investigaciones biológicas y la ética en el manejo del 
El referido enfoque derivaba de la idea de que el derecho, como visión sistémica, debería consagrar una seguridad jurídica pura (o algo próximo de ello), dentro de un cuadro extremamente dogmático-histórico-evolutivo. Es el período de auge del liberalismo, galvanizado en las ideas, sobre todo, de JOHN LOCKE ${ }^{48}$, su gran ideólogo y ADAM SMITH.

En lo que atañe específicamente a las obligaciones en general, el ideario político-filosófico derivado del liberalismo, desde nuestra perspectiva, impuso, a los contratos y contratantes, un deber dogmático de conducta calcado en la estricta observancia de aquello que fuera anteriormente prometido, de modo de no tolerar o aceptar ninguna ulterior flexibilización posible o necesaria.

Dicho de otro modo, nadie era obligado a contratar; sin embargo, ejercida la voluntad autónoma de vincularse a cualquier contrato, la promesa realizada debería ser integralmente cumplida. Así de simple.

patrimonio genético de las personas y los alimentos en general (BOBBIO, N., "A Era dos Direitos”, traducción de Carlos Nelson Coutinho, Campus, Rio de Janeiro, 1992).

48 JOHN LOCKE, a pesar de sus ideas consideradas liberales, en su vida particular sostenía una visión de mundo diametralmente opuesta. Por ejemplo, es notoria su postura extremamente reaccionaria e inadecuada en favor de la esclavitud, al mismo tiempo en que defendía, contradictoriamente, la igualdad entre los hombres. 
Esta visión contractual de índole liberal sufrió severas moderaciones y limitaciones a partir de comienzos del siglo XX, cuando, por un lado se moduló la cláusula "pacta sunt servanda", merced a los excepcionales acontecimientos derivados, en gran medida, de la Primera Guerra Mundial (ver "Infra" capítulo específico sobre este tema, más detallado y profundizado) y, por el otro lado, la llegada de un nuevo período histórico, en franca contraposición al liberalismo ya existente, denominado intervencionismo estatal ("welfare state").

La concepción del intervencionismo estatal tiene como base central a dos sistemas políticos antagónicos, la socialdemocracia, con todos los matices conocidos y el socialismo que, de la misma forma que el primero, se presenta con varias facetas. ${ }^{49}$

Los sistemas económicos que derivaron de estas dos concepciones políticas (Capitalismo y Estado regulador), paradojalmente, ostentaban, como base jurídica fundamental, a nuestro modo de ver, el principio de la legalidad, dentro de un sistema de naturaleza predominantemente social. Esta conjunción de factores, como consecuencia, permeó el pensamiento jurídico más creativo del siglo $\mathrm{XX} .^{50}$

\footnotetext{
${ }^{49}$ El término socialismo, conforme la mayoría de los historiadores contemporáneos, es extenso y abarcador, incluyendo en la misma vertiente ideológica, varios colores y matices, muchas veces difíciles de ser identificados a primera vista (por ejemplo, anarquistas, marxistas, leninistas, maoístas, castristas, etc.).
}

${ }^{50}$ Obsérvense, por ejemplo, las fecundas y originales doctrinas de KARL LARENZ, LOUIS JOSSERAND y ALBERTO ASQUINI, que tuvieron fuerte impacto en la vida 
El período citado tiene en KARL

GUNNAR NYRDAL ${ }^{51}$ su principal exponente, siendo que sus ideas sirvieron para convalidar y conferir legitimidad al mantenimiento de un Estado regulador y protector del ciudadano, desde su nacimiento hasta su muerte.

Aunque el intervencionismo estatal personifique una idea dictatorial, en cierta medida, por parte del Estado, es menester reconocer que se trata de un sistema, dentro de una visión sin prejuicios del operador del derecho, de naturaleza social, objetivando también la seguridad jurídica.

Es evidente que en el período referido se vislumbra una fuerte tendencia en admitir, en el universo de los contratos, una posibilidad de análisis posterior del contenido obligacional contratado, todo ello bajo ciertas circunstancias. No obstante lo antedicho, se observa, que la matriz central, para la interpretación ulterior de lo que fuera acordado, se asienta, en última instancia, en la tentativa de establecer reglas cerradas y estrictas para disciplinar lo imponderable.

de los contratos, en la medida en que se pasó a admitir una cierta modulación y calibración, para la necesaria protección de contratantes débiles e hiposuficientes (así considerados por elección política del legislador), como también para alteraciones contractuales posibles de la economía primaria del negocio que diera ocasión para el contrato originariamente suscripto.

${ }^{51}$ Famoso economista y sociólogo sueco, premio Nobel de Economía de 1974. 
Solamente a finales del siglo XX, con la reinvención del liberalismo, bajo su nuevo ropaje neoliberal, es que la matriz del sistema pasó a ser o perfeccionada y se crearon reglamentos jurídicos de tutela efectiva de derechos humanos, buscando la construcción de nuevos mecanismos de armonización y tolerancia de los contrarios.

En este nuevo contexto es que debe ser colocado el contrato, en el perímetro de la posmodernidad, donde, aunque se busque, como visión sistémica, la seguridad social, presente en los dos últimos períodos históricos citados (liberalismo e intervencionismo estatal), se observa una creciente necesidad de armonización de los contrarios.

Ello explica, en gran parte, en la actual fase neoliberal, la abundancia de normas jurídicas con tipos abiertos, representativas del otorgamiento, por parte del legislador ordinario, de un poder discrecional más intenso al magistrado para la solución de los conflictos de intereses surgidos, en contraposición a los sistemas jurídicos del siglo XIX, que preferían, de forma mayoritaria, las normas jurídicas del tipo cerrado. ${ }^{52}$

\footnotetext{
52 Sobre la cuestión, buscando conceptualizar lo que sería una norma jurídica de tipo abierto, JORGE TOSTA, ilustre magistrado y profesor brasileño, elucida que "con la industrialización y la ampliación de las relaciones comerciales, las codificaciones de Europa, especialmente las de los países de tradición romano-germánica, pasaron a sufrir una verdadera 'inflación normativa', lo que, sin embargo, no evitó la desactualización de los textos legales frente a las alteraciones semánticas derivadas de nuevos valores incorporados por la sociedad. En este ambiente de transformaciones y restablecimiento de la confianza en el órgano juzgador es que surgen las normas de tipo abierto,
} 
En este orden de ideas existe, como consecuencia, una creciente tendencia a la flexibilización de aquello que fue originariamente contratado, para alcanzar, en lo que atañe a la disciplina jurídica de las obligaciones, una concreta y efectiva función social de los contratos, que se inserta, de manera incontrovertible, en nuestro sentir, en el arco mayor de prevalencia de un sistema que protege y favorece, de forma más intensa y clara, los derechos humanos. ${ }^{53}$.

No es por otra razón que tuvo lugar la construcción de una efervescente línea de pensamiento atrincherada en función social de los contratos y en la obligatoriedad, como norma objetiva de conducta, de la observancia, por parte de los contratantes, de los significativos postulados de probidad, lisura y buena fe, con todas las exigencias deontológicas de ello derivadas.

permeadas por términos vagos o indeterminados y representadas, la mayoría de las veces, por lo que se denomina modernamente cláusula general” (TOSTA, J., "Manual de Interpretação do Código Civil - As normas de tipo aberto e os poderes do juiz”, $1^{\text {a }}$ edición, Campus Jurídico, pp. 9 - 10).

${ }^{53}$ Ver, nuevamente, en relación a este tema, la obra de NORBERTO BOBBIO, en su contextualización del Derecho Contractual en esta posmodernidad, con perfil social, como derechos de tercera generación. (BOBBIO, N., "A Era dos Direitos", traducción de Carlos Nelson Coutinho, Campus, Rio de Janeiro, 1992). 
Es más, el concepto de buena fe, en el presente momento histórico de la posmodernidad, además de albergar la idea de conducta proba y correcta objetiva, a ser adoptada por las partes suscriptoras del acuerdo, representa un ineludible reglamento deontológico, pasando a ser exigencia de conducta a ser observada meridianamente por cualquier ciudadano en la ejecución e implementación de actos ordinarios, de cualquier naturaleza de la vida cotidiana.

Estos conceptos - reglas generales de conducta y buena fe de los contratantes - serán analizados, seguidamente, en capítulo específico y destacado, que tiene como telón de fondo al contrato como instrumento eficaz para el pleno ejercicio de la ciudadanía y de los derechos sociales garantizados por los actuales sistemas de derechos humanos (con base, siempre, en el estado democrático de derecho), adoptados, con mayor o menor intensidad por las legislaciones occidentales. 


\section{LA REAL FUNCIÓN DEL CONTRATO Y SU EFECTIVO Y CONCRETO ALCANCE SOCIAL}

\subsection{La buena fe contractual como matriz integradora de la función social del contrato}

Establecidos os principios basilares del

contrato, "Iatu sensu", pasamos, ahora, al enfrentamiento concreto da su correcta función, que, como es sabido, en primer lugar, deriva de su natural y siempre presente aspecto económico. En realidad, la función más destacada dei contrato es, efectivamente, la de carácter económico, ya que aquél tiene, como telón de fondo, la idea de propiciar la circulación de riqueza existente, transfiriéndola de un patrimonio a otro, bajo ciertas condiciones libremente pactadas por los contratantes.

En otras palabras, como corolario lógico de todo lo que fue dicho hasta aquí, el contrato siempre representó el más eficaz instrumento para la libre circulación de riquezas, ejerciendo una creciente función reguladora en la evolución económica de la propia humanidad, que deriva exactamente de los derechos y obligaciones asumidas por los contratantes en el libre ejercicios de sus voluntades, eu un ambiente de plenas libertades civiles y democráticas. De esto decanta, naturalmente, la creciente función social del contrato, consagrada como cláusula general en los sistemas jurídicos. 
Representa, por lo tanto, además de una función económica, una verdadera función social, puesto que permite, en un contexto de libre iniciativa ${ }^{54}$ y libertad para contratar, pilares de las economías más avanzadas, especialmente en este comienzo de siglo, la valorización, en definitiva, del trabajo humano, exponiendo un mecanismo de efectiva paz social, consagrado en la "lex privada", derivada del propio contrato, teniendo por límite y perímetro aquello que es permitido y aquello que no es permitido por el derecho positivo de las legislaciones de los pueblos libres.

Todo ello, obviamente, permeado por la buena fe de los contratantes que, en el marco de la funcionalidad social del contrato, gana extrema relevancia, como se verá más adelante, especialmente en lo que atañe a la forma mediante la cual las partes deben ejecutar y cumplir los contratos.

Dicho de otra manera, aunque la concepción de la función social del contrato, que siempre derivará de su natural función económica, desde la antigüedad hasta los días de hoy, no esté enteramente definida, es correcto sostener, hasta por las más elementales reglas de la experiencia común, que conlleva limitaciones. $\mathrm{O}$

${ }^{54}$ En Brasil, por ejemplo, el ideario ideológico de la libre iniciativa está nítidamente plasmado en el saludable y correcto comando constitucional derivado del art. 170 de la Constitución, "in verbis": "A ordem econômica, fundada na valorização do trabalho e na livre iniciativa, tem por fim assegurar a todos existência digna, conforme os ditames de justiça social..." (En traducción libre: "El orden económico, fundado en la valorización del trabajo y en la libre iniciativa, tiene por fin asegurar a todos existencia digna, conforme los dictados de la justicia social...”.) 
sea, su zona de actuación, a la par de sus naturales efectos internos (inter partes), delimita eficaces efectos externos, por lo que podemos afirmar que no es tolerada por el derecho la creación de un contrato que sirva de vehículo para la producción y mantenimiento de efectos dañosos a terceros o a la propia sociedad como un todo. Por ejemplo, basándonos en una situación dramática pero real, no se puede tolerar como lícito y legal un contrato firmado entre el ya extinto Partido Nacional - Socialista Alemán (nazista) y el fabricante de gas Zyclon-B, para proveer ese material en los campos de exterminio de seres humanos durante la Segunda Guerra Mundial.

El profesor brasileño MIGUEL REALE, mentor del nuevo Código Civil de Brasil, en vigor desde el año 2002, analizando la extensión de la expresión "función social del contrato" como norma obligatoria cristalizada en el artículo 421 del nuevo Código Civil Brasileño/02, preconiza que "la libertad de contratar será ejercida en razón y en los límites de la función social del contrato. Así, los contratos deberán cumplir no sólo la función de instrumentar la circulación de riquezas, sino también la libertad contractual. En realidad, esta cláusula actuará como legítima cláusula multifuncional, permitiendo que los casos que escapen de la incidencia del artículo 51 del Código de Defensa del Consumidor sean examinados a partir de este dispositivo. Siendo así, las cláusulas contractuales que no atiendan la disposición prevista expresamente en el nuevo dispositivo del Código Civil podrán ser revisadas y anuladas." 55

\footnotetext{
${ }^{55}$ REALE, M., "Visão Geral do Projeto de Código Civil”, São Paulo, 1986, p. 9.
} 
En la misma línea de razonamiento, podemos observar lo dicho por el profesor brasileño FERNANDO NORONHA, quien sobre el tema aduce lo siguiente: "En suma, la buena fe objetiva fundamenta la obligación vinculante de los contratos porque es necesario que se tutele la confianza de la contraparte de que la declaración será cumplida. El contrato no es intangible por respeto a la intención de las partes o al derecho adquirido a un resultado predeterminado por el contrato. A la sociedad le interesa que los pactos sean observados no porque debe cumplirse la voluntad de las partes, no por la palabra en sí, sino porque es imprescindible que se protejan las expectativas creadas por las declaraciones de voluntad." 56

En el mismo sentido, el también profesor brasileño PAULO NALIM, buscando encontrar un concepto posmoderno para el contrato, contextualizándolo dentro de una perspectiva social, sin olvidar su función económica, sustenta, con propiedad, que "en el actual estado de comprensión de la doctrina nacional acerca de la función social del contrato, evidenciada la completa indefinición sobre el tema, se hace oportuna una sugestión. A mi modo de ver, se divide la función social en intrínseca y extrínseca. La primera - intrínseca - es relativa a la observación de principios nuevos o descriptos nuevamente por los titulares contratantes, todos derivados de la gran cláusula constitucional de la solidaridad, sin que haya un inmediato cuestionamiento acerca del principio de la relatividad de los contratos. Su perfil extrínseco, a su vez rompe con el aludido principio, preocupándose con las repercusiones en el

\footnotetext{
${ }^{56}$ NORONHA, F., "O direito dos contratos e seus princípios fundamentais: autonomia privada, boa-fé, justiça contratual”, Saraiva, São Paulo, 1994.
} 
ancho campo de las relaciones sociales, puesto que el contrato en tal diseño a otros titulares que no son sólo aquellos inmediatamente involucrados en la relación jurídica de crédito." 57

\subsection{La buena fe contractual como matriz integradora de la función social del contrato}

En este orden de ideas, se pasa a exigir actualmente de los contratantes, con mayor intensidad y vigor, la adopción de una conducta transparente en las fases preliminares (de tratativas y negociaciones) y definitivas de los acuerdos suscriptos o a suscribirse, inclusive en lo que atañe a su correcta ejecución. En otras palabras, esa conducta debe exteriorizar una postura de buena fe en el contexto general del contrato, o sea, la adopción de una conducta correcta, leal, proba, dentro de un perímetro de extrema integridad, que invariablemente debe ser observada por la persona honesta promedio, cumplidora de sus deberes y obligaciones, o más precisamente, aquello que otrora los romanos afirmaron, con extrema sabiduría, ser la conducta correcta del buen padre de familia.

En definitiva, conforme lo expuesto supra, las matrices de conducta que los contratantes deben observar, tanto en la ultimación como en la ejecución del contrato, bajo la óptica de su

${ }^{57}$ NALIM, P., “Do contrato: conceito pós-moderno em busca de sua formulação na perspectiva civil-constitucional”, Juruá, Curitiba, 2001. 


\section{Alteración de las Circunstancias y Revisión Contractual}

función social, se galvanizan en la idea del cumplimiento de la prestación acordada. Teniendo como telón de fondo el feliz entendimiento, presente en el moderno Derecho Alemán, de efectiva obligación en el implemento de la prestación asumida y en la utilización de comportamiento idoneo y probo conforme "los usos del tráfico." 5859

58 Esta es la expresión clara, de sencilla interpretación, del art. 242 del BGB ("Prestación según buena fe"), que establece que "el deudor está obligado a cumplir la prestación según las exigencias de la buena fe conforme a los usos del tráfico". La norma referida, obviamente, no provee una definición de la buena fe. Sin embargo, remite al operador del derecho a la idea central de su función estrictamente reguladora. Esto lo lleva a cabo al definir, claramente, que las obligaciones deben ser cumplidas (en la doctrina alemana tradicional, a través de la denominada "konkretisierungsfunktion" función reguladora) y además, requieren ese cumplimiento teniendo por referencia los específicos límites existentes en otras normas frecuentes dentro del propio sistema. Las mismas, establecen, equitativamente, derechos y deberes entre las partes contratantes (en la doctrina alemana tradicional, a través de la schrankenfunktion - función limitadora). Al respecto, para un análisis más profundo, ver HENNRICHS, J., "Treupflichten im Aktienrecht/zugleich Überlegungen zur Konhretisierung der Generalklausel des 242 BGB sowie zur Eigenhaftung des Stimmechtsvertreters”, AcP 195,1995 .

59 La doctrina jurisprudencial española, también comulga, a lo que parece, con el entendimiento de que la buena fe, en última instancia, carece todavía de una formulación conceptual positiva y concreta. Es un ejemplo efectivo, a este respecto, la interesante sentencia del Tribunal Supremo del 9 de octubre de 1998, “in verbis": "La buena fe contractual, según posición consolidada en la doctrina civilista, supone un complejo de normas jurídicas que carecen de una formulación positiva y concreta, y que conforman una seria de principios que la conciencia social estima como necesarios, aunque no hayan sido formulados por el legislador, ni establecidos por los usos contractuales" (Sentencia colacionada por JUAN FRANCISCO DELGADO DE 
Como análisis final, puede afirmarse, sin margen de error, que la buena fe representa un conjunto sano de normas de conducta, siendo el propio origen de los deberes a ser observados por los contratantes, tanto en el período de formación del contrato, como en el periodo de su ejecución. ${ }^{60}$

Dicho de otro modo, en el universo contractual, cada contratante debe adoptar un comportamiento congruente, ético y leal, derivado de un estado de conciencia que se basa (o debe basarse) en la plena convicción de que procede con integridad, lealtad y ética, dentro de ciertos padrones consolidados en la sociedad en determinado momento histórico, buscando actuar con la mayor transparencia posible en todas las fases del contrato, hasta su final. ${ }^{61} 6263$.

MIGUEL, in "Instituciones de Derecho Privado", Tomo II, Obligaciones y contratos, Vol. $2^{\circ}$., p. 161, Thomson Civitas, 2004).

60 "En relación a la primera categoría, bastará observar que el principio básico de la buena fe se extiende, no sólo a la ejecución del contrato (al cumplimiento de la obligación y al ejercicio del correspondiente derecho de crédito), sino también al periodo de la preparación y formación del mismo - ANTUNES VARELA, J., "Das obligaciones en geral”, Vol. I, $2^{\mathrm{a}}$ edición, Livraria Almedina, Coimbra.

${ }^{61}$ La buena fe, por lo tanto, entre otras directrices de conducta, remite las partes a una ideología contractual de cooperación mutua, que estriba, sobre todo, en la confianza recíproca. Esta idea cooperativa en torno a los contratantes fue bien delineada por JORGE MOSSET ITURRASPE, cuando expresa que "la persona tiene el deber social 


\section{Alteración de las Circunstancias y Revisión Contractual}

de cooperar para la consecución del bien común, del cual obviamente participa. La vivencia de los valores de solidaridad y cooperación, generalmente dejada de lado o preterida por los juristas, debe presidir su actividad y marcar su vida cotidiana. Ello obliga a la persona a colaborar en la realización de otras personas, para lo cual debe también abstenerse de toda acción contraria a ese propósito" (MOSSET ITURRASPE, J., "Interpretación económica de los contratos", Rubinzal - Culzoni, Buenos Aires, 1994, p. 31).

${ }^{62}$ Constatar, igualmente, en el mismo sentido, a JORGE MAYO, que nos ilustra con lo siguiente: "Se trata de la función de control y de límite al actuar de los sujetos. No funciona en este supuesto como medio o instrumento para integrar, a través de deberes accesorios, la obligación el contrato, sino que representa un limite que debe retenerse como inmanente e intrínseco al ejercicio de cualquier pretensión o al cumplimiento de cualquier deber (obligacional)", MAYO, J., "Estudio de Derecho Civil”, La Ley, Buenos Aires, 2005, p. 11. - En este orden de ideas, se advierte una semejanza con el uso del criterio de la equidad. Sin embargo, sólo un mero parecido, pues a diferencia del criterio equitativo, no se trata de una valoración, de segundo grado que, en base a las circunstancias, provoca a corregir y atemperar el rigor del strictum jus. Aquí tenemos una valoración de primer grado que, en base a criterios y parámetros o estándares objetivos de comportamiento, lleva a modificar, suspender, o reducir, la aplicación de las regulae luris, contribuyendo de tal modo, a asegurar un necesario elemento vinculante entre las reglas legales y los valores sociales y éticamente fundados (siempre mutables). Aparece, entonces, la posibilidad bien concreta, de considerar que al emplear la cláusula general de la buena fe en función del límite a la accionabilidad de derechos y pretensiones, se esta entrando directamente en el área del abuso del derecho, entendido en sentido subjetivo, como ejercicio de un derecho no sustentado con motivos éticamente justificables. Componentes de egoísmo y contradicción, califican tal comportamiento."

63 No por otra razón fue que, ya en el siglo XIX, el insigne jurista español FLORENCIO GARCIA GOYENA, de la Universidad de Salamanca, tratando 
Se exige, por lo tanto, una conducta absolutamente leal, honesta, honrada y proba (que representa la integridad personal), entre los contratantes al momento en que son pactadas las cláusulas y condiciones del contrato.

Dentro de estas exigencias éticas y deontológicas, los contratantes deben referir, detalladamente, los hechos relacionados con el contrato y, sobre todo, la forma por medio de la cual el mismo será, ulteriormente, ejecutado (especialmente en aquellos acuerdos de ejecución continuada o diferida), no traicionando, bajo ninguna hipótesis, la confianza primaria depositada.

En la actualidad, dentro de los sistemas legislativos occidentales más modernos, se adopta, como regla de carácter obligatorio, algún dispositivo legal que consagra a obligatoriedad de la observancia de la buena fe objetiva. A este respecto, reforzando lo antedicho, el Código Civil Brasileño, antes mencionado, en su clara redacción del art. 422 preconiza, con fuerza de norma de cumplimiento forzoso, que "los contratantes están obligados a guardar, así en la conclusión del contrato, como en su ejecución, los principios de probidad y buena fe."

puntualmente el asunto de marras, al comentar el proyecto del Código Civil Español de 1851 (del cual fue uno de los exponentes más destacados de la Comisión General de Codificación), leccionaba que "la equidad y la buena fe son el alma de los contratos" (GARCIA GOYENA, F., “Comentarios, motivos y concordancias del Código Civil Español”, Tomo III, Madrid, 1852, p. 9). 
Consonante con el prolífico magisterio de la profesora MARIA HELENA DINIZ, este dispositivo impone "que haya entre las partes una colaboración en el sentido de mutuo auxilio en la tratativa negocial, en formación, en la ejecución y en la extinción del contrato, impidiendo que una dificulte la acción de la otra." 64

De ahí, a través de esta ilación, se puede afirmar que la buena fe objetiva debe ser rigurosamente observada por los contratantes tanto en la fase da asunción de las obligaciones preliminares, como en la secuencia posterior de la ejecución del propio contrato suscripto, siempre teniendo como telón de fondo la función social de los contratos.

Es por ello que, en este mosaico, está vedada la práctica por parte de los contratantes de comportamiento contradictorio ("venire contra facium proprium"), que pueda traducir, eventualmente y en última instancia, la sustracción de la confianza primaria que motivó originalmente a las partes para contratar, y que engloba, lógicamente, todas las conductas de lealtad, honestidad, honradez y probidad esperadas.

\footnotetext{
${ }^{64}$ DINIZ, M.H., “Curso de Direito Civil Brasileiro - Teoria das obrigações contratuais e extracontratuais”, 26a edición, Saraiva, São Paulo, p. 33.
} 
En el ámbito de los contratos que alberguen el surgimiento eventual de prestaciones excesivamente onerosas, y dentro de las reglas deontológicas ya citadas, la inserción del principio de la buena fe objetiva también debe llevar al acreedor a evitar el agravamiento del prejuicio del otro contratante, que ciertamente ocurrirá, siempre que sobrevenga una alteración substancial de las circunstancias, con el consecuente rompimiento de la negocial originaria.

En conclusión, la concreta violación de los deberes citados, especialmente en cuanto al agravamiento del perjuicio de uno de los contratantes, puede informar, concretamente, una conducta de mala fe de la parte que, potencialmente, pueda ser beneficiada por el desequilibrio contractual excesivo surgido ulteriormente en la fase de ejecución del contrato, a posteriori de su ultimación.

Merece finalmente, intenso elogio, la adopción, sobre todo por parte del legislador occidental, del criterio de buena fe objetiva a ser observada en los contratos de forma general. Ello, en contraposición a la buena fe subjetiva, que podría, eventualmente, dar margen a equívocos y errores de interpretación en casos específicos, cuando fuese necesaria la valoración de las conductas singulares de las partes en los casos concretos, a efectos de permitirse un juicio correcto y justo.

Dicho de otra forma, el contratante malicioso, que no haya adoptado una conducta recta y proba, podría, 
eventualmente, valerse de los criterios poco densos de la buena fe subjetiva, para esconder y camuflar sus aspiraciones negativas, perjudicando derechos ajenos. $^{65}$

Precisamente sobre este tema de la observancia de la buena fe en los contratos, en contraposición a la postura desleal, el maestro ROBERT POTHIER, siempre con maestría impar, sustentaba, hace siglos, que "en el foro íntimo, debe verse como contrario a esa buena fe todo aquello que se separa, por poco que sea, de la más exacta y más escrupulosa sinceridad; el simple disimular respecto a algo referente a la cosa objeto del negocio, y que la parte con quien contrato tenga interés en conocer, es contraria a esa buena fe, puesto que, si recomendamos amar al prójimo como a nosotros mismos, no podemos ocultarle nada que no queremos que nos sea ocultado, estando en su lugar." 66

A un mismo nivel el eminente doctrinario civilista español LUIS DIEZ-PICAZO, sustenta, con gran propiedad, que "la obligatoriedad del contrato se funda, pues, de acuerdo

${ }^{65}$ Consonante con la esmerada doctrina unánime, la buena fe subjetiva, a su vez, incluye entendimiento erróneo, falsa creencia, ignorancia excusable o estado de consciencia caracterizado por la ignorancia, es decir estar en el "propio estado (subjetivo) de la ignorancia (como en casos de hipótesis de casamiento putativo, de adquisición de propiedad ajena mediante a usucapión, etc.), como por errónea apariencia de cierto acto (mandato aparente, heredero aparente, etc.)".

${ }^{66}$ POTHIER, R., Tratado das Obrigações, traducción de Adrain Sotero Batista y Douglas Dias Ferreira, Servanda, Campinas, 2002, p. 53. 
con esta idea en una norma ética derivada de la buena fe, que exige no defraudar la confianza que en otro pueda haber creado nuestra promesa o nuestra conducta. En definitiva, se trata de lo que el autor citado denomina la norma ética de veracidad en nuestras comunicaciones con el prójimo, y que ordinariamente se expresa como deber de atenerse a la palabra dada. No cabe duda que una posición como la transcripta, al tratar de fundamentar todo el derecho de la contratación en imperativos de orden ético, entraña un importante avance en la moralización por la vía del orden jurídico de las relaciones sociales." 67

En Brasil, el jurista MARCOS JORGE CATALAN, en la misma línea de razonamiento sustenta que “(...) el principio de la buena fe objetiva merece ser leído dentro de su contexto plurisignificativo, no pudiendo ser limitado a cualquier concepto reduccionista, unívoco, bajo pena de restricción de su efectiva importancia para el bienestar de la teoría general de los negocios jurídicos. Así, en la lección de Judith Martins Costa, a la idea de buena fe objetiva debe ser atribuida una triple función, puesto que sirve como criterio hermenéuticointegrador en el proceso de exégesis de los negocios jurídicos; de cercanía al ejercicio pleno de los derechos subjetivos, y también actúa como elemento de fecundación de los deberes laterales de conducta". ${ }^{68}$, sin olvidar el verdadero contenido real de los contratos cuando sea necesaria

${ }^{67}$ DIEZ-PICAZO, L., “Fundamentos del derecho civil patrimonial”, Tecnos, Madrid, 1970 , p. 63.

${ }^{68}$ CATALÁN, M.J., “Descumprimento contratual”, Juruá, 2005, p.76. 
tal valoración por el poder judicial, con vistas a la eventual solución de controversia. $^{69}$

Además, en Brasil, el nuevo sistema jurídico de derecho privado, que trajo aparejado el nacimiento del nuevo Código Civil (2002), con nuevas reglas de conducta derivadas del derecho vigente, pasó a imponer a las partes contratantes que éstas resguarden, tanto en la conclusión del contrato, como en su propia ejecución, los principios de probidad y buena fe, no pudiendo ser dejados de lado, conforme la regla, ahora obligatoria, derivada del artículo 422 de aquel "codex" (verbis: "los contratantes son obligados a guardar, así en la conclusión del contrato, como en su ejecución, los principios de probidad y buena fe").

Analizando aquel dispositivo legal, su real alcance jurídico y extensión, los eminentes doctrinarios brasileños NELSON NERY JUNIOR y ROSA MARIA DE ANDRADE NERY agregan que "la norma prevé, como cláusula general, la buena fe objetiva. Igualmente, en las disposiciones finales y transitorias, prescribe que

69 "Los contratos son lo que son y la calificación no depende de las denominaciones que les hayan dado los contratantes porque para la calificación que constituye una labor inserta dentro de la interpretación, habrá de estarse al contenido real, es decir que habrá de realizarse de conformidad con el contenido obligacional convenido y el protagonismo que las partes adquieren, con prevalencia de la intención de las mismas sobre el sentido gramatical de las palabras, al tener carácter relevante el verdadero fin jurídico que los contratantes pretendían alcanzar con el contrato." Sentencia del Tribunal Supremo, Sala de lo Civil, del 21 de Julio de 2006, no recurso 4401/1999, Ponente Don Pedro González Poveda. A favor de Sociedad Recurrida. (Base de Datos Economist \& Jurist, Avance de Jurisprudencia). 
ninguna convención prevalecerá se contraria preceptos de orden público, tales como los establecidos por el Código Civil para el resguardo de la función social de la propiedad y de la función social de los contratos (Código Civil, art. 2034, párrafo único). Al intérprete, a su vez, incumbe la exégesis del negocio jurídico en consonancia con los principios del sistema." 70

En rigor, tal postura sustenta el correcto entendimiento de que, en los sistemas jurídicos más avanzados de Derecho Privado, la regla de la buena fe, a ser observada en los contratos, es considerada cláusula de carácter general, con nítida función instrumentadora. ${ }^{71} 72$

70 NERY JUNIOR, N., y ANDRADE NERY, M., "Código civil comentado $e$ legislação extravagante”, 3 a edición, Revista dos Tribunais, 2005, p.380.

${ }^{71}$ Disertando sobre este apasionante tema, el mismo NERY JÚNIOR preconiza que “como las cláusulas generales tienen función instrumentadora, porque dan vida a lo que se encuentra contenido, abstracta y genéricamente, en los principios generales del Derecho y en los conceptos legales indeterminados, son más concretas y efectivas que esos dos institutos. Cláusula general no es principio, tampoco regla de interpretación; es norma jurídica, esto es, fuente creadora de derechos y de obligaciones" - in autor citado - Artículo incluido en la Revista de Direito Privado 10/179, Brasil, Revista dos Tribunais, "La base objetiva del negocio jurídico, el seguro de vida en grupo y la relación de consumo”.

72 Dentro de esta misma línea, “verbi gratia”, el sistema jurídico español también consagra la regla de buena fe como cláusula de carácter general y de integración, "ex vi" de la mejor interpretación del art. 1258 del Código Civil Español: "los contratos se 
De la presente forma, analizándose la extensión de las reflexiones supra y retro colocadas, se extrae, en primer lugar-, la conclusión de que la función social del contrato, además de representar un efectivo mecanismo de concreto equilibrio entre la relación fáctico-jurídica de los contratantes originarios, también debe traducir reflejos positivos del negocio jurídico formalizado, frente a terceros, o sea, en la comunidad y en el respectivo medio social.

Esto porque, evidentemente, el negocio jurídico ajustado, vía el contrato respectivo, siendo adecuadamente implementado, desempeñado y cumplido, con lealtad y buena fe, no solamente acarreará los beneficios deseados para los contratantes

perfeccionan por el mero consentimiento, y desde entonces obligan, no sólo al cumplimiento de lo expresamente pactado, sino también a todas las consecuencias que, según su naturaleza, sean conformes a la buena fe, al uso y a la ley”. En América Latina, más precisamente en el derecho argentino, también se contempla el mismo concepto general y de integración en el art. 1198 del Código Civil de la Nación Argentina: "los contratos deben celebrase, interpretarse y ejecutarse de buena fe y de acuerdo con lo que verosímilmente las partes entendieron o pudieron entender, obrando con cuidado y previsión". También el nuevo Código Civil de Bolivia (Decreto ley $\mathrm{n}^{\circ}$ 12.760), por ejemplo, al abordar el tema, igualmente consagra la buena fe como elemento que no puede ser dejado de lado en la integración de los contratos, al establecer, en su art. 520, que "el contrato debe ser ejecutado de buena fe y obliga no sólo a lo que se ha expresado en él, sino también a todos los efectos que deriven conforme a su naturaleza, según la ley, o a falta de ésta según los usos y la equidad”. 
originarios, sino también beneficios para toda la colectividad del mismo universo geográfico, máxime en un mundo actual extremamente globalizado y sofisticado, donde las relaciones personales, con mayor o menor intensidad, se plasman y se mezclan, por obra de nuevas tecnologías, con grandes reflejos en la esfera macro jurídica de la propia sociedad.

De ahí, como corolario, la conclusión que no puede ser dejada de lado: el principio de buena fe se relaciona mucho más con la real interpretación del contrato que con su estructura. El análisis de cualquier contrato, por lo tanto, deber vivificar la concreta intención de las partes, cuando exteriorizaron la correspondiente declaración de voluntad, al momento de la ultimación del pacto.

Ello porque, como factor acumulativo, que debe estar sujeto a los postulados de la buena fe anteriormente mencionados, tiene que ser observado de la misma forma, por todos los contratantes. El principio de la confianza es, ciertamente, una consecuencia fundamental e ineludible del principio de la buena fe.

Dicho de otra forma, el principio de la confianza es un derivado concreto del principio de la buena fe, en la medida en que aquél debe asentarse en declaraciones claras y no ambiguas. 
Debe exteriorizar, así, por parte de cualquiera de los contratantes, una declaración seria, que debe personificar una intención de igual calibre ${ }^{73}$.

Para reafirmar lo expresado, esta idea de confianza es el corolario de la buena fe que debe ser empleada por las partes, bajo cualquier ángulo que se valore, jurídicamente hablando, el contrato respectivo, máxime teniendo en cuenta que el propio ordenamiento jurídico - especialmente el de los países occidentales acoge, muchas veces, la buena fe bajo diferentes prismas, pero siempre le atribuye efectos convergentes.

En caso de eventual controversia (conflicto), tendrá que analizarse, en primer lugar, la presencia o no, de la buena fe de los contratantes, tanto en la formación como en la ejecución del contrato. Ell con la idea de informar una ulterior solución correcta o, como mínimo, razonable, dentro de la lógica de lo razonable, preconizada por RECASENS SICHES. ${ }^{74}$ Esta postura esperada de buena fe y lealtad debe,

\footnotetext{
${ }^{73}$ Todos los sistemas jurídicos occidentales, inspirados en el deber de buena fe de las partes, concretamente, construyeron normas jurídicas puntuales de interpretación contractual. En este sentido, habiendo controversia en relación a determinado acuerdo suscripto, si éste presenta cláusulas ambiguas, contradictorias, dubitativas o deficientemente redactadas, debe ser interpretado en contra de aquel contratante que redactó, efectivamente, el instrumento de marras, pues el mismo, en el momento de su construcción, pudiendo ser claro y límpido, no lo fue.

74 “La técnica hermenéutica de lo 'razonable', o del 'logo del humano', es la que realmente se ajusta a la naturaleza de la interpretación y de la adaptación de la norma al caso. La dimensión de la vida humana, dentro de la cual está el Derecho, así lo reclama.
} 


\section{Alteración de las Circunstancias y Revisión Contractual}

igualmente, ser mantenida por los eventuales contratantes (incluisve por los letrados) en hipótesis de eventual litigio, en el ambiente del proceso civil respectivo. ${ }^{75}$.

El fetichismo de la norma abstracta aniquila la realidad de la vida. La lógica tradicional, de tipo matemático o silogístico, no le sirve al jurista, ni para comprender e interpretar de modo justo los dispositivos legales, ni para adaptarlos a las circunstancias de los casos concretos. El juez realiza, en la gran mayoría de los casos, un trabajo de adaptación de la ley al caso concreto, según criterios valorativos ajenos a los moldes silogísticos". ("In" autor citado "apud" SILVEIRA, A., "Hermenêutica do Derecho Brasileiro", Revista dos Tribunais, Vol. I, 1968, p. 83). Debiendo siempre recordarse que este análisis, a cargo del Estado-juez, cuando instado para la correcta solución del conflicto instaurado, como regla general (o cuando sea el caso de elección, por las partes, del juicio arbitral / justicia privada), representa una auténtica valoración de la conducta de los contratantes, dentro de ciertos postulados éticos y morales, vigentes en aquel momento histórico, en la sociedad en la cual se inserta el pacto, que vendrán a desautorizar comportamientos desleales.

${ }^{75}$ A este respecto sustentamos en el III Congreso Nacional de Práctica Profesional, realizado en la ciudad de Azul, Argentina, 2009, tesis relacionada con la necesaria conducta de las partes en senda de la buena fe y del abogado ético en el proceso "Impresiones sobre la buena fe en el Derecho Procesal Civil Brasileño". - Breves comentarios del art. $17^{\circ}$ del Código de Proceso Civil Brasileño: 1.El alto alcance público del proceso civil, asentado en la correcta verificación de hechos y acontecimientos sucedidos, como presupuestos de la incidencia adecuada de la ley a la hipótesis concreta, para la justa composición de la lid, en la lección, siempre recordada, de Carnelutti, no puede obviamente prescindir de la participación y colaboración ética de los litigantes, desde la proposición de la demanda hasta su efectivo desahogo final, con el otorgamiento de la correspondiente prestación jurisdiccional. 2. Por esa razón es que el legislador procesal brasileño, históricamente, ha prestigiado la observación de conductas éticas que, necesariamente, deben implementarse por los litigantes, en el desarrollo y composición de la lid dentro de la idea central que las partes en litigio, 


\section{Alteración de las Circunstancias y Revisión Contractual}

además del claro interés concreto en la declaración y reconocimiento de sus eventuales derechos, deben también ejercer una importante función ética en la conducción y desarrollo regular del proceso, en el sentido de la recta invocación y aplicación de las normas jurídicas existentes, además de la correcta exposición de los hechos. 3. En este contexto, la buena fe de los litigantes debe siempre estar presente en el sitio de la lid, porque las partes, aunque dentro del contexto de un ambiente de conflicto de intereses, deben observar un primado ético objetivo y un primado de verdad, colaborando, así, para la justa solución del litigio, por el nacimiento de una decisión judicial que, dentro de un perímetro de lealtad procesal, pueda darle, en final análisis, a cada uno lo que es suyo. Deber de buena fe y deber de lealtad. 4. Establecidas esas premisas, que imponen a los litigantes la necesidad de la correcta conducta en el desarrollo del litigio, es menester conceptuarse lo que sea deber de buena fe o deber de lealtad, en el ámbito del derecho procesal civil. 5. Inicialmente, como principio general, por buena fe se debe entender aquella conducta correcta, leal, prueba que, invariablemente, es observada por la persona medio honesta, cumplidora de sus deberes, o, más precisamente, aquello que los romanos afirmaron ser la correcta conducta del buen padre de familia. En el universo procesal, debe traducirse la idea del litigante correcto y leal, tanto con relación al Estado-juez, cuanto con relación al adversario. En otras palabras, es aquel comportamiento congruente, derivado de un estado de conciencia que se basa en la plena convicción de que se procede con lealtad, tanto con relación al derecho buscado, cuanto con relación al encaminamiento de la pretensión respectiva, para ulterior eventual reconocimiento del derecho afirmado en juicio, por prestación de la correspondiente tutela jurisdiccional. 6. Según lo dicho anteriormente, el deber de buena fe y de lealtad procesal es inherente a la postura ética que el litigante, desde luego, debe asumir en la conducción y encaminamiento del proceso del cual participa, sea activamente o pasivamente, en la parte que le toca. Siendo principio general de orientación, el legislador brasileño caracterizó las hipótesis concretas, en el art. 17 del Código de Proceso Civil, estableciendo las posturas consideradas, bajo su punto de vista, como reprobables y que, en cada caso concreto, cuando probadas, pueden justificar la imposición de una indemnización, por daño procesal, en favor del litigante inocente. (FERNANDES ALMEIDA, R. -“Impresiones sobre buena fe en el Derecho Procesal Civil Brasileño" - Ponencia apresentada ante el III Congreso Nacional de Práctica Profesional, Cidad Azul, Argentina, 2009). 
Puede afirmarse, así, sin margen de error, que las normas que disciplinan la buena fe de los contratantes, en tal universo, representan, en una final interpretación, verdaderas normas abiertas, donde el legislador ordinario, siguiendo la tendencia creciente en ese sentido, acaba por delegar al Magistrado (Estado-Juez) un significativo y mayor poder discrecional, como forma de permitir, después del análisis de cada caso concreto, una mejor calibración de la cláusula general de la buena fe, prestando una mayor flexibilidad y libertad. ${ }^{76}$

${ }^{76}$ Al respecto, al analizarse la existencia y aplicación de las normas dichas "abiertas", se debe acompañar la explicación autorizada del Profesor ARRUDA ALVIM, de la Universidad Católica de São Paulo que en su célebre obra, "A argüição de relevância no recurso extraordinário", enseña que "el margen intencional de 'libertad', que deriva de la flexibilidad de la norma, significa que se depositó, deliberadamente, en el criterio de sus aplicadores, elementos componentes de raciocinio y de sensibilidad destinados para que se llegue a una conclusión, lo que prácticamente es inexistente en los modelos analíticos de norma jurídica. En éste, intencionalmente, el legislador no da mayor margen de libertad al aplicador de la norma, aunque haya que aceptar un margen que no puede suprimirse de 'libertad', la cual, si bien se tuvo la intención de no atribuir al aplicador de la ley, en el orden vivencial y dinámico del Derecho, en términos prácticos, no produce supresión total de libertad del juzgador. Esta 'libertad' está aquí expresada y realizada, vía interpretación de la norma. La actividad del aplicador de la norma vaga, sin embargo, se aproxima, al menos en su resultado, mutatis mutandis, a la actividad del legislador, si bien que jurídicamente no lo sea y ni intencionalmente actúe con el fin de legislar, ya que tampoco le fue adjudicado tal poder' (ALVIM, A., “A argüição de relevância no recurso extraordinário" $1^{\text {a }}$ edición, Revista dos Tribunais, 1988, p. 55). 


\section{CAPÍtULU II}

1. La cláusula "rebus sic stantibus" y la flexibilización de la primacía del "pacta sunt servanda". Breve esbozo histórico de la cláusula "rebus sic stantibus"

2. Resurgimiento de la cláusula "rebus sic stantibus" 


\section{LA CLÁUSULA “REBUS SIC STANTIBUS” Y LA FLEXIBILIZACIÓN DE LA PRIMACÍA DEL “PACTA SUNT SERVANDA”. BREVE RESUMEN HISTÓRICO DE LA CLÁUSULA “REBUS SIC STANTIBUS"}

Como ya fue con suficiencia evidenciado anteriormente, como regla general, los contratos, cuando legítimamente firmados, observados fundamentalmente los principios ya invocados y su creciente función social, que debe orientar la voluntad de los contratantes, deben ser efectivamente cumplidos, dentro de un contexto mayor que el de la lex privada, asentada en la necesaria buena fe, libertad para contratar y en la autonomía de la voluntad.

Sin embargo, en ciertos casos, en llamados contratos de ejecución continuada o de tracto sucesivo (contratos en que la conducta exigida para el cumplimiento de los mismos a los contratantes es sucesiva y regular, diferentemente de los llamados contratos instantáneos, que se perfeccionan de manera inmediata), tal principio sufre severas restricciones, cuando, por razones extraordinarias, sobrevinientes al contrato, no previstas razonablemente por las partes, uno de los contratantes pasa a arcar con una prestación extremamente onerosa, que coloca en jaque la necesaria equivalencia de las prestaciones. 
Para evitar, así, la perpetuación de una prestación exorbitante y extremamente penosa, con sacrificios desproporcionales para una de las partes, resurgió, a fines de la Primera Guerra Mundial, rompiendo con la postura individualista vigente hasta entonces, la posibilidad de invocación de la cláusula "rebus sic stantibus" (en traducción libre, “(...) estando así las cosas”), necesariamente siempre implícita en los contratos bilaterales, de ejecución continuada o de tracto sucesivo.

En realidad, la cláusula "rebus sic stantibus" era parte de una fórmula que se daba por subentendida, latente, oculta en todo contrato de ejecución continuada o de tracto sucesivo. Esa fórmula, atribuida, originariamente a BÁRTOLO DE SASSOFERRATO ${ }^{77}$, era compuesta de un elemento mayor, asentado en la expresión "contractus quid habent tractum successivum et de pendentiam de futuro rebus sic stantibus intelliguntur", también, tal fórmula, aunque de forma muy tímida había aparecido ya en la Antigüedad en el Código de HAMURABI. ${ }^{78}$

\footnotetext{
${ }^{77}$ SASSOFERRATO, BÁRTOLO, 1.314/1.357 — "Omnia quae extam opera", Vol. II, Venecia, 1603, p. 256.
}

${ }^{78}$ Conforme registros históricos, HAMURABI fue uno de los mayores reyes de la Mesopotamia (actual Irak), en el siglo XVIII a.C. y, en esa condición, redactó un conjunto de leyes conocido como "Código de Hamurabi", con base, fundamentalmente, en antiguos sistemas de leyes sumerias, poseyendo 282 artículos, divididos en 14 capítulos. En capítulo IV, que trata de locaciones, mutuo y dación en pago, hay, en el artículo 48, un claro dispositivo que autoriza la modificación de las condiciones de un contrato de mutuo, por causa del sobrevenir de una situación imprevisible: "se alguien tiene un débito con intereses, y una tempestad devasta su campo o destruye la cosecha, 
En una traducción libre, tal máxima jurídica quiere decir que los contratos que tienen tracto sucesivo y dependen de cumplimiento futuro, se consideran exigibles permaneciendo las cosas así, o sea, en los contratos de tracto sucesivo o a término, el vínculo obligatorio se entiende subordinado a la continuación de aquel estado de hecho, vigente al tiempo de la estipulación. Sin embargo, tal fórmula pasó a ser conocida solamente a través de la expresión resumida "rebus sic stantibus".

Sin embargo, los doctrinarios históricos no habían llegado a un consenso real y efectivo respecto al origen regular de este concepto, hay una fuerte tendencia, preconizada principalmente por el jurista italiano GIUSSEPE OSTI, que el punto de partida de la elaboración jurídica de esta cláusula se basaba en la filosofía estoica de los filósofos CÍCERO e SÊNECA, en posición opuesta al entendimiento de que su origen derivaría de las fuentes canónicas medievales.

CÍCERO, eminente filósofo estoico ${ }^{79}$ en su célebre obra "Officcus ad marcum filium", escrita en la quinta década de

o por falta de agua no crece el trigo en el campo, no deberá en ese año dar trigo al acreedor, deberá modificar su tabla de contrato y no pagar intereses por ese año".

${ }^{79}$ El estoicismo, escuela filosófica de la Antigüedad, fundada por Zenón de Cítio, busca, básicamente, la felicidad suprema, en una actividad constante para vivir en armonía con la naturaleza, aceptando, con gran coraje todas las vicisitudes. 
nuestra era, afirmaba lo siguiente "se nos presentan muchas veces circunstancias en las cuales las cosas que parecen eminentemente justas, para aquel que llamamos hombre honrado, cambian de naturaleza y toman un carácter opuesto. Así, en ciertas ocasiones, será conforme a la justicia no restituir el depósito, no cumplir la promesa, desconocer la verdad y la fe empeñada (...). La alteración de los tiempos y de las circunstancias llevan a la alteración de la verdad.", 80

SÉNECA, otro ilustre integrante de la escuela filosófica del estoicismo, condiciona, en la misma línea de lo expuesto supra, en su obra "De benefiicis", el cumplimiento efectivo de la obligación a la permanencia de las cosas en el estado en que se dio la promesa. Las palabras del maestro convergen para convalidar, plenamente, la línea de conducta capaz de autorizar una revisión de lo que fue prometido, presentes circunstancias cambiantes, informadoras de una onerosidad no prevista anteriormente, verbis: "[el] menor cambio me deja enteramente libre para modificar mi determinación, desobligándome de la promesa. Le prometí mi asistencia como abogado, sin embargo, comprobé que su pretendida acción era contra mi padre. Le prometí acompañarlo en viaje: supe, después, que ese camino está lleno de ladrones; le prometí patrocinio, sin embargo, mi hijo se ha puesto enfermo o mi mujer está con dolores de parto. Todas esas cosas deben estar en la misma situación que en

${ }^{80}$ CÍCERO, apud OTHON SIDOU, J.M., “A revisão judicial dos contratos e outras figuras jurídicas", Forense, São Paulo, 1978. 
la del momento que le prometí, para que pueda reclamar esa promesa como obligación." 81

Por otro lado, tenemos también, la corriente que sustenta que su efectivo origen derivaría de las fuentes canónicas, por causa de la verdadera sistematización de la cláusula emprendida por los juristas canónicos de los siglos XII y XIII, teniendo como telón de fondo al Derecho Natural, asentado en el carácter cristiano y divino, que también debe orientar las relaciones entre personas. Los canonistas de mayor proyección, fueron Santo Tomás de Aquino, San Agustín, San Graciano y San Bartolomé, por citar los más prominentes.

En otras palabras, en la Edad Media, por franca inspiración de los postulados del Derecho Canónico, se agregaron al mundo jurídico de entonces, los cerrados valores morales cristianos, apoyados, fundamentalmente, en las doctrinas de San Agustín y Santo Tomás de Aquino, después galvanizadas en las enseñanzas de GRACIANO.$^{82}$ Por ejemplo, SAN AGUSTÍN, ya en el siglo IV, ponderaba

${ }^{81}$ SENECA, apud DIAS, M.L., "Da revisão judicial dos contratos pela aplicação da teoria da imprevisão”, Revista da Pontifícia Universidade Católica de São Paulo, Brasil, Vol. XLIII / 155.

82 Graciano, también conocido como FRANCISCUS GRACIANUS, fue religioso y jurista de Boloña, con actuación en los siglos XII y XIII, ya que, tanto la fecha de su nacimiento, como la de su muerte, son desconocidas. Es considerado, por los doctos, como el padre del Derecho Canónico, por causa de su célebre obra "Concordia discordantium canonum", también conocida como Decreto de Graciano, unificadora del 
que no habría infidelidad alguna por el no cumplimiento de una promesa, desde que ocurriese alguna cosa que viniese a impedir la fiel ejecución de la misma. ${ }^{83}$.

Siguiendo la misma línea de razonamiento, SANTO TOMAS, inspirado en la moralidad de Séneca, doctrinaba que, para estar obligado a lo que se prometió, sería necesario que todas las circunstancias, existentes al tiempo del pacto, permaneciesen inalteradas. ${ }^{84}$ En las motivaciones supra referidas, todas íntimamente unidas a la rígida moral cristiana del momento histórico respectivo, plasmaban la idea de una regla de eminente carácter moral.

Derecho en la Iglesia medieval (en una traducción libre, "Concordancia de las Discordancias de los Cánones", que, como su nombre lo indica, tuvo por objeto la conciliación de cánones entonces existentes y derivados de los siglos pasados), que tuvo vigencia hasta el año 1917, cuando sobrevino, en mundo jurídico cristiano, el "Codex Juris Canonici".

${ }^{83}$ En palabras textuales de San Agustín, "quando autem aliud occurrit, quod imprevidit fidem promissionis meae, non mentiri volui, sed promissium implere non potui”. Traducción libre: "cuando ocurre alguna cosa de mayor importancia que impida la ejecución fiel de mi promesa, no quise mentir, sólo no pude cumplir lo que prometî"' (In autor citado, "Sermones Adpopulum”, p. 133).

${ }^{84}$ Santo Tomás de Aquino, apud Klang, M., - "A teoria da imprevisão e a revisão os contratos”, Revista dos Tribunais, Río de Janeiro, 1983. 
$\mathrm{Su}$ transformación en regla jurídica efectiva sobrevino, solamente en Italia, cuando el citado FRANCISCO GRACIANO, célebre profesor de la Escuela de Derecho de Boloña, en el "Decretus Gratiani”, ya mencionado, incorporó la disposición de la obligatoriedad de el mantenimiento de las mismas condiciones de la contratación para obligar el cumplimiento de una promesa futura.

En este contexto diversificado, derivado de diversas literaturas y visiones del mundo, sobrevino la célebre forma atribuida, como fuera afirmado anteriormente, a BÁRTOLO DE SASSOFERRATO, jurista pos glosador del siglo XIV, anteriormente analizada. ${ }^{85}$.

Así, merced a las concepciones supra comentadas, en los contratos de larga duración, se consideraba siempre subentendida la cláusula de que sólo valen manteniéndose las condiciones en que fueron estipuladas originariamente ("contractus que habent tractum sucesivum at dependentium de futuro rebus sic stantibus inteliguntur").

Se trataba, como fue expuesto antes, subrayándose nuevamente, del antiguo concepto, ciertamente derivado de las inclinaciones moralizadoras del espíritu del jurista medieval, con franca inspiración en el Derecho Canónico Medieval, asentada en la filosofía cristiana fundamentalista, y que cayó en desuso a inicios de la era moderna,

${ }^{85}$ SASSOFERATO, BÁRTOLO - 1314/1357 - "Omnia quae extam opera", Vol. II, Venecia, 1603, p. 256. 
sucumbiendo al creciente imperio del individualismo, principalmente a partir de finales del siglo XVIII.

También, siguiendo en esta línea, de acuerdo con los doctrinarios brasileños WASHINGTON DE BARROS MONTEIRO $^{86}$, ARNOLD WALD $^{87}$ y SÍLVIO RODRIGUES ${ }^{88}$, cupo a los glosadores y posglosadores la enunciación de la cláusula "rebus sic stantibus". Por otro lado, HUGO GROTIUS, en posición análoga a la de OSTI, entendía que la orientación de la voluntad debe poseer no solamente su causa impulsiva investigada, sino también, la causa final. No existiendo esta última, no existirá la obligación.

En la Europa del siglo XVIII, por ejemplo, aún de forma tímida, tal cláusula estaba prevista expresamente en el Código Civil de Baviera, de 1756, aunque sufriese algunas limitaciones, para adecuarla al macro sistema jurídico entonces vigente en la región.

\footnotetext{
${ }^{86}$ DE BARROS MONTEIRO, W., "Curso de direito civil: direito das obrigações”, Vo. IV, $29^{a}$ edición $4^{\circ}$, Saraiva, São Paulo, 1997.

${ }^{87}$ WALD, A., “Obrigações e contratos”, Revista dos tribunais, São Paulo, 2000.

${ }^{88}$ RODRIGUES, S., “Direito Civil”, Vol. III, Saraiva, São Paulo.
} 
La cláusula también fue utilizada en

1774 por Prusia y en 1811 aparece en el Código austríaco. En el derecho portugués clásico, reproducido en las ordenaciones Alfonsinas, Manuelinas y Filipinas, ya se observaba la utilización de la cláusula, por lo cual, en algunas situaciones especiales, cabía la posibilidad de alteración de las condiciones de los acuerdos.

A causa de este pasado histórico, la cláusula fue incluida en el Código Civil Portugués, a mediados del siglo XIX. Sin embargo, a pesar del tímido resurgimiento en algunas legislaciones europeas, tal cláusula, en aquel periodo, no era ampliamente utilizada. Esto porque, históricamente hablando, en el siglo XIX se vivía en un mundo de cierta seguridad económica, con monedas relativamente estables, monarquías milenarias y legislaciones que, reflejando ese momento histórico enaltecían, en demasía, los principios de la autonomía de la voluntad humana y de la irrectractabilidad de las convenciones, generando tal entendimiento, como consecuencia directa, el debilitamiento y desinterés en la aplicación de la cláusula "rebus sic stantibus" en las relaciones privadas entonces existentes.

Es decir, la adopción, en algunos ordenamientos jurídicos positivos de Europa, de la cláusula "rebus sic stantibus", derivaban de posicionamientos puntuales, sin una mayor repercusión en el mundo jurídico europeo más elevado de la época. Ello, a causa del surgimiento, a finales del siglo XVIII y comienzos del XIX, de 
nuevas doctrinas económicas, centradas en el individualismo, por lo que se dio un nuevo enaltecimiento de la cláusula "pacta sunt servanda". 89

Sin embargo, como se verá y se demostrará en el capítulo siguiente, a inicios del siglo XX sobrevino, con intensidad sin igual, el rescate de la "rebus sic stantibus". Ello trajo aparejado, como consecuencia, en función de factores económicos y políticos, una nueva mitigación de la cláusula "pacta sunt servanda".

${ }^{89}$ A este respecto, absolutamente pertinentes son las ponderaciones del Profesor CARLOS ALBERTO BITTAR FILHO: "soplaban los vientos de dos revoluciones: la inglesa, económica, y la francesa, política. Se expandía el individualismo, cuyos reflejos en el mundo jurídico fueron nuevas concepciones asentadas en la autonomía de la voluntad y en la irreversibilidad de los ajustes. Esta tendencia fue sostenida expresamente por el Código Napoleónico (art.1134), en estos términos: 'Las convenciones legalmente formadas equivalen a ley para aquellos que las hicieron'. Por extensión, lo mismo ocurrió donde tal código ejerció su influencia. Se cristalizó, por lo tanto, el principio "pacta sunt servanda" (BITTAR FILHO, C.A., "Teoria da imprevisão: sentido atual”, Revista dos Tribunais, $\mathrm{n}^{\circ}$ 679, mayo de 1992, São Paulo, pp. 18-29). 


\section{RESURGIMIENTO DE LA CLÁUSULA "REBUS SIC STANTIBUS”}

La doctrina expuesta, como fue visto, de la "teoría de la imprevisión", con su potencial origen en el Derecho Canónico Medieval, pasó a admitir, probado el surgimiento de circunstancia extraordinaria o imprevisible, la posibilidad de pedido de revisión o resolución del contrato por parte del contratante en posición de desventaja, de forma de autorizarse, judicialmente, el pleno restablecimiento de la situación de equidad al momento de la celebración del pacto, o, no siendo esto posible, su inmediata resolución sin culpa de la parte.

En otras palabras, la Primera Guerra Mundial (1914/1918) hizo renacer la cláusula "rebus sic stantibus". Las situaciones extremamente especiales del primer gran conflicto mundial tuvieron el poder de rescatar el principio medieval de moral y de derecho, asentado, en última instancia, como ya fue expuesto, en la moral cristiana vigente, que, consideraba injusto el lucro de un individuo derivado de la alteración, ulterior, de las circunstancias concretas bajo el imperio de las cuales las obligaciones habían sido estipuladas.

Es verdad que, reiterando lo dicho, durante muchos años, la teoría estuvo alejada de las consideraciones de los legisladores de finales del siglo XVIII y parte del siglo XIX (periodo del surgimiento de las grandes codificaciones europeas), siendo, sin embargo, 
rescatada a causa del surgimiento de un período turbulento de la historia moderna, con fuente en una gran conflagración mundial, que vino a afectar, individualmente, las esferas jurídico-obligacionales de aquellos que, luchando en la guerra, habían dejado obligaciones pendientes y no resueltas. De esta forma, el cumplimiento del contrato, en un ambiente absolutamente atípico e imprevisible, pasó a representar un sacrificio absolutamente injusto para aquellos que volvían del frente, que llevaba, no pocas veces, a la total ruina económica del sujeto obligado.

Así, en este clima, el gobierno francés, al final de la guerra, flexibilizó los principios de la cláusula "pacta sunt servanda", en el ámbito del derecho positivo francés entonces vigente, promulgando, el 21 de Mayo de 1918, la conocidísima Ley Failliot, según la cual, en resumen, durante el conflicto y hasta tres meses después del cese de hostilidades, los contratos comerciales celebrados antes del 1 de Agosto de 1914, cuyo cumplimiento dependiese del futuro, podrían ser resueltos, sin perjuicio que no ocurriese ninguna de las causas establecidas por el derecho común o convenidas por las partes, si, en virtud del estado de guerra, la ejecución de las obligaciones de cualquiera de los contratantes les causase perjuicios, cuya importancia excediese en mucho las previsiones que razonablemente pudiesen haber sido hechas al tiempo de la convención.

Ese incuestionable quiebre con el verdadero dogma jurídico, vigente hasta entonces, de la cláusula "pacta sunt servanda" derivó, en última instancia, de las demandas sociales específicas de un determinado momento histórico especial. El derecho, 
históricamente hablando, siempre es obligado y compelido a irse adaptando a las situaciones fácticas que surgen por causa del contexto social, político, económico y hasta ambiental. No puede permanecer inmutable, estático, inmovilizado y trabado, rindiendo pleitesía a principios carcomidos, rígidos e inflexibles, sólo porque son supuestamente sabios o porque, por una razón u otra, consiguieron atravesar incólumes una centena de años.

Tal posición, abriendo un pequeño paréntesis, vino a ser, posteriormente, en el período que media entre las dos grandes conflagraciones mundiales, ampliamente apoyada en la doctrina italiana, con inclusión normativa en el Código Italiano de 1942, que obtuvo una amplia difusión posterior, especialmente en el Brasil. Ello porque, en el país sudamericano, como ya fue expuesto, merced a la sanción del nuevo Código Civil del año 2002, su sistema jurídico de obligaciones y contratos pasó a contemplar, concretamente, la posibilidad de aplicación de la resolución del mismo por onerosidad excesiva o su equitativa modificación, con el restablecimiento de la equivalencia de las prestaciones, siendo eso jurídicamente posible, conforme los arts. 478 a 480 del nuevo dispositivo legal.

En el ámbito de los Países de América del Sur específicamente los integrantes del MERCOSUR, además de Brasil, Argentina, normativamente, introdujo tal doctrina en su derecho positivo, ex vi del art. 1198, párrafo $1^{\circ}$, del Código Civil de la Nación Argentina. Por su parte, Uruguay, otro de los países socios del bloque, extrañamente, no tiene previsión legal en su codificación que permita la 
aplicación de tal teoría, en cambio, Paraguay, en su nuevo Código Civil, contempla la aplicación de la misma.

La principal causa que refrenda la inserción, en términos normativos, de algún dispositivo que contemple la revisión contractual por causa de onerosidad excesiva sobreviniente, con seguridad, encuentra eco y soporte en la idea de que, contemporáneamente, en las sociedades posmodernas, no existe espacio para concebir dogmáticamente - un sistema contractual absolutamente cerrado y sólido, insensible las posibles y necesarias alteraciones posteriores, de cualquier naturaleza, pero sobre todo fácticas.

A este respecto, la idea de fluidez del sistema encuentra viva referencia en los conceptos vanguardistas posmodernos de ZYGMUNT BAUMAN, profesor emérito de sociología de la Universidad de Varsovia y Leeds, uno de los más eruditos e instigantes "cronistas-filósofos" de la vida contemporánea. El autor sostiene, con mucha propiedad y perspicacia, la existencia actual de una modernidad inmediata y ligera, fluida y líquida, en contraposición con la modernidad sólida, pesada y estática, que fue inexorablemente suplantada por la primera. En su ya célebre obra Modernidad Líquida, el sociólogo polaco sostiene que "la sociedad que entra en el siglo XXI no es menos 'moderna' que la que entró en el siglo XX; lo máximo que puede decirse es que ella es moderna de un modo diferente." 
Concluyendo el referido autor afirma, con todas las letras, que "dos características, sin embargo, hacen nuestra situación - nuestra forma de modernidad - nueva y diferente. La primera es el colapso gradual y el rápido ocaso de la antigua ilusión moderna: la creencia que existe un fin en el camino por el que transitamos, un 'telos' al que se llegará con el cambio histórico, un estado de perfección a ser alcanzado mañana, el año que viene o el próximo milenio, algún tipo de sociedad buena y justa, sin conflictos en todos o algunos de sus aspectos postulados, a saber: el firme equilibrio entre oferta y demanda y la satisfacción de todas las necesidades; el orden perfecto, en el que todo es colocado en el lugar correcto, nada de lo que está fuera de lugar persiste y ningún lugar es puesto en duda; las cosas humanas se hacen totalmente transparentes porque se sabe todo lo que debe ser sabido; el completo dominio sobre el futuro - tan completo que pone fin a toda contingencia, disputa, ambivalencia y consecuencias imprevistas de las iniciativas humanas." 90

Esta idea de fluidez se identifica, enormemente, con la nueva dinámica de los contratos, donde la antigua concepción que todo pacto debe ser rigurosamente cumplido, como matriz sólida e incuestionable, anida una noción anacrónica de solidez pretendidamente eterna que no existe más. Ello es un hecho incontrastable, perceptible a simple vista por las más elementales reglas ordinarias de la experiencia común.

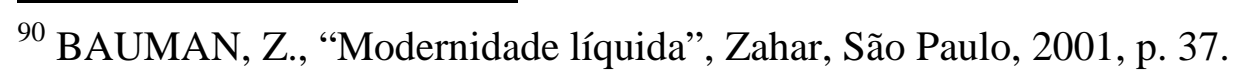


Actualmente, las relaciones humanas, de cualquier naturaleza que sean, están normalmente permeadas por una idea constante de inseguridad, traducidas en los estímulos negativos que orbitan alrededor de la vida cotidiana de los individuos. Por ejemplo, las cuestiones y demandas crecientes en torno al tema ambiental y las cuestiones de seguridad nacional e internacional contra una lógica perversa del terror contemporáneo, absurdamente diseminada en el mundo globalizado de hoy son claras y significativas muestras y señales de ese nuevo orden en el que estamos insertos.

En el ámbito de los contratos, por obvio que parezca, esos sentimientos de inseguridad también se hacen presentes, especialmente en lo que se refiere a la vida de los contratos y a la forma por la cual los mismos deben ser ejecutados y cumplidos.

Todos los individuos, de un modo general, están viviendo, hoy en día, en espacios geográficos precarios e inestables. Existe una creciente falta de garantías y una ausencia, en mayor o menor medida, de dominio sobre el futuro, en contraposición a la idea de absoluta certidumbre que, en el pasado reciente, servía de referencia primaria para las relaciones humanas. Ello cedió paso, actualmente, a una lógica de inseguridad casi absoluta, que se refleja también en el universo de los contratos y sus desdoblamientos fáctico-jurídicos. 
DAVID RULLE, a propósito del acápite, dentro de esta noción de un orden centrado en la deconstrucción de los dogmas de una modernidad hace mucho superada, preconiza que "tratados de economía (...) dan la impresión de que el papel de los legisladores y miembros responsables del gobierno es encontrar e implementar un equilibrio particularmente favorable para la comunidad. Ejemplos de caos en la física nos enseñan, sin embargo, que en vez de llevar a un equilibrio, ciertas situaciones dinámicas activan desarrollos temporariamente caóticos e imprevisibles. Los legisladores y gobernantes responsables deben, por lo tanto, considerar la posibilidad de que sus decisiones, que buscan producir un equilibrio mejor, podrán, en vez de eso, generar oscilaciones violentas e imprevistas, con efectos posiblemente desastrosos." 91

De este modo, para resumir, observamos que la mentalidad firme y consistente de otrora, plasmada en la pretendida solidez de las convenciones y en la obligatoriedad de cumplimiento absoluto de los contratos, aún los de largo plazo, actualmente se disocia, cada vez con más vigor, de la realidad de la vida cotidiana en la posmodernidad.

Más adelante, en el capítulo específico y destacado, serán enfrentados y discutidos, en términos de su efectiva extensión, los dispositivos legales, de los países mencionados, y las

${ }^{91}$ RULLE, D., "Hasard et chaos”, Odile Jacob, Paris, 1991, p. 90. 
potenciales lagunas, que tratan de la materia, incluyéndose el análisis de algunos precedentes jurisprudenciales, en el perímetro jurisdiccional del Brasil.

En este sentido, y con la necesidad de conferirle una evolución lógica a esta exposición, serán debatidos y detallados los principales puntos doctrinarios que propagan la denominada teoría de la imprevisión, principalmente la necesaria profundización del debate relacionado con la imperiosa necesidad, en última instancia, de mantenerse la base del negocio jurídico y la equivalencia material de las prestaciones, en los contratos de tracto sucesivo o de ejecución continuada. 


\section{CAPÍTULO III}

1. El contrato en calidad de experiencia económica y sus riesgos inherentes

2. La alteración de la economía del contrato por la alteración de las circunstancias: el necesario mantenimiento de la equivalencia material de las prestaciones en los contratos de ejecución continuada y de tracto sucesivo

2.1. La cláusula "hardship": concepto y aplicabilidad 


\section{EL CONTRATO EN CALIDAD DE EXPERIENCIA ECONÓMICA Y SUS RIESGOS INHERENTES}

La mayor parte de las relaciones de derecho privado son nítidamente obligacionales. Dicha ilación deriva de reglas ordinarias de experiencia común más elementales, siendo una de las más importantes facetas del denominado Estado liberal, en la línea de pensamiento sustentada por ADAM SMITH, al preconizar que "es suficiente que dejemos al hombre abandonado a su iniciativa para que al perseguir su propio interés promueva el de los demás. El interés privado es el motor de la vida económica". ${ }^{92}$

Por otro lado, conforme la pacífica y meridiana doctrina, la economía se ocupa de los fenómenos de producción, circulación y consumo de bienes. En ese orden de ideas, la importancia social del contrato deriva exactamente de la necesidad de la creación de mecanismos reguladores equilibrados, mínimamente confiables, y que atiendan los intereses económicos de las partes involucradas. Éstas son las que autónomamente crean, a través del nuevo instrumento firmado (el propio contrato), un nuevo orden de relaciones fáctico-jurídicas

\footnotetext{
${ }^{92}$ SMITH, A., "The Wealth of Nation”, Metalibri Digital Library.
} 
debidamente ajustadas, de carácter principalmente económico y que, evidentemente, proviene de la libre voluntad de los contratantes.

Cada parte, por lo tanto, busca ajustar sus intereses económicos en el molde mayor de las normas positivas que se insertan dentro de un determinado sistema jurídico, sin olvidar que la interpretación de las mismas puede - y debe - ser valorada por la jurisprudencia. En este amplio espacio normativo, están incluidos el principio de libertad contractual, como premisa mayor, las cláusulas generales, las cláusulas generales contractuales y las cláusulas libremente pactadas por los contratantes, teniendo como perímetro aquello que la ley (sistema normativo) efectivamente permite y autoriza.

El contrato revela de esta forma, en términos estrictamente económicos, por un lado, una idea de poder y, por el otro, una idea de sumisión relativa de ciertos intereses, debidamente negociados entre los contratantes, con el objetivo final de extraerse un contenido económico de aquello que fue libremente convenido.

No es por otra razón que CLARE DALTON afirma, con propiedad, en términos macro jurídicos, que "la doctrina del contrato está organizada en torno de las cuestiones del poder y del conocimiento. Todas las dualidades tradicionales del Derecho Privado (público-privado, objetivo-subjetivo, forma-sustancia) reflejan la 'tensión 
básica' entre el yo y los otros y los problemas de poder y de conocimiento que surgen de esa relación." 93

Por otro lado, como consecuencia de esa premisa mayor, establecida de forma distinguida por la autora citada supra, los contratantes, en su respectivo microcosmos jurídico, acuerdan, para la plena satisfacción y calibración de sus intereses, la creación y nacimiento de un nuevo orden de relaciones obligacionales, debidamente ajustadas en términos económicos.

Todo lo antedicho, evidentemente, teniendo como telón de fondo la libertad contractual, siempre presente en los sistemas libres y democráticos (con mayor o menor intensidad), que según el emérito jurista lusitano ANTUNES VARELA, representa la "facultad de crear sin coacción un instrumento objetivo, un pacto que, una vez concluido, niega a cada una de las partes la posibilidad de dejarlo de lado de forma unilateral - 'pacta sunt servanda'. La razón de la vinculación está en que la promesa libremente aceptada por cada una de las partes crea expectativas fundadas en relación a la otra y el acuerdo realiza fines dignos de ser tutelados por el Derecho. Al interés de la libre ordenación de los intereses recíprocos de las partes sucede la necesidad de

93 DALTON, C., "An essay in the deconstruction of contract doctrine”, Yale, L.J., 1985, p. 997 y ssgtes. 
protección de la confianza de cada una de ellas en la validez del pacto suscripto." 94

En el mismo sentido encontramos los conceptos del reputado INÔCENCIO GALVÃO TELES, cuando preconiza que "se denomina negocio jurídico el acto productor de efectos jurídicos que representan una aplicación del principio de la autonomía de la voluntad, traduciendo una autorregulación de intereses." 95

Por lo tanto, dado lo expuesto, el fin especial del contrato (regla de carácter genérico) deriva con exactitud de la forma libre y soberana por la cual las partes pactaron sus intereses, que a su vez, albergan aspectos económicos de mayor o menor intensidad, dependiendo del tipo y modelo de acuerdo adoptado por los contratantes interesados.

Por ese motivo es que el sistema jurídico siempre buscó tutelar, con mayor o menor intensidad, dependiendo del contexto histórico, el mantenimiento del equilibrio económico, de forma consciente o no, en diversos y consolidados preceptos e institutos

\footnotetext{
${ }^{94}$ ANTUNES VARELA, J.M., “Das obrigações em geral”, Vol. I, 9a edición, Coimbra, 1996.

95 GALVÃO TELES, I., "Direito das obrigações”, 7ª edición, Editorial Coimbra, Coimbra.
} 
jurídicos, destacándose, por ejemplo, la lesión y la evicción, entre otros relevantes.

A partir de allí surge la necesidad de construir y establecer, a través de los tiempos, mecanismos seguros para que la alteración de las circunstancias, relacionadas con determinado contrato, no represente, en última instancia, la total ruina económica del contratante en desventaja. De ahí que tengamos desde el nacimiento de la cláusula "rebus sic stantibus", en la Edad Media, hasta el actual derecho alemán, en este tercer milenio, el tratamiento del mismo asunto con ropaje más moderno, estribado en el denominado Derecho de la perturbación de las prestaciones (a ser tratado, más detalladamente, en tópico posterior).

El desafío, por lo tanto, en esta senda, consiste en buscar parámetros seguros para mantener la economía del contrato (siempre que sobrevenga una alteración de las circunstancias en los aspectos fáctico-jurídicos en los cuales se asentó la voluntad originaria del contratante), máxime en este actual contexto histórico, propio de la posmodernidad, de existencia de relaciones jurídicas nítidamente globalizadas.

En relación a este tema específico, PETER BENSON preconiza que "el derecho de los contratos alcanzó un nivel de aparente completitud y aceptabilidad que, dentro de ciertos parámetros relativamente uniformes (como se observa en la proximidad de muchas propuestas regulatorias en articulados internacionales sobre 
derecho de los contratos), es similar en estructuras jurídicas al civil law y common law, y se encuentra también en un nivel globalizado." 96

\title{
2. LA ALTERACIÓN DE LA ECONOMÍA DEL CONTRATO POR LA ALTERACIÓN DE LAS CIRCUNSTANCIAS: EL NECESARIO MANTENIMIENTO DE LA EQUIVALENCIA MATERIAL DE LAS PRESTACIONES EN LOS CONTRATOS DE EJECUCIÓN CONTINUADA Y DE TRACTO SUCESIVO
}

\begin{abstract}
Cuando se habla de contrato, implícitamente se reconoce en ese instrumento un vehículo saludable y democrático que busca (o debe buscar) la amplia satisfacción de las partes, especialmente, como ya fue subrayado, en un acuerdo de tracto sucesivo o diferido. En realidad, las partes contratantes, al pactar, de forma autónoma, sus intereses, ya están realizando el fin social del contrato, como vehículo de garantía mínima de las cláusulas y condiciones acordadas.
\end{abstract}

\footnotetext{
${ }^{96}$ BENSON, P., "The unity of contract law”, New essays, Cambridge University Press, 2001, pp. 118-205.
} 
Hasta por las más elementales reglas de la experiencia común, cuando alguien se vincula contractualmente a otro, lo hace teniendo como reserva mental la idea de que dicho pacto le es, al momento del ajuste, por lo menos, meridianamente satisfactorio, y que las prestaciones convenidas se equivalen al momento de la contratación. Es la propia esencia de la economía del contrato.

Por eso mismo es que, en este contexto, las posiciones que sufragan, como verdadero dogma, la rigidez de la cláusula "pacta sunt servanda", derivan de teorías construidas basadas en el inflexible entendimiento de que los contratos deben ser rigurosamente cumplidos, tal como ocurría desde el antiguo Derecho Quiritario.

No obstante, la dicha construcción dogmática debe sufrir severas limitaciones, en la medida en que parte de una premisa manifiestamente equivocada, representada por el entendimiento de que el cumplimiento de las prestaciones debe representar un verdadero dogma, inmune a cualesquier cuestionamientos ulteriores, sean de la naturaleza que sean.

La matriz objetiva y subjetiva debe ser otra: cualquier contrato de ejecución continuada o diferida o de tracto sucesivo, ya en su elaboración, debe incluir la idea alternativa de que podrá no ser satisfactoriamente o integralmente cumplido, si sobreviene un cambio radical de las circunstancias. Esta premisa precisa estar presente al 
momento de la suscripción del contrato, preferencialmente de forma expresa.

En otras palabras, las doctrinas tradicionales siempre parten de la premisa de que los acontecimientos imprevisibles representan la excepción. Sin embargo, es exactamente al contrario: las partes contratantes deben estar absolutamente preparadas para lo imponderable e imprevisible. Habrá, por lo tanto, siempre una franja razonable de imprevisibilidad, con mayor o menor intensidad, frente a los contratos de ejecución continuada o diferida. En dicho sentido, la imprevisibilidad debe ostentar, en los acuerdos suscriptos, el "status" de regla general.

Nadie, de forma pensada y razonable, conscientemente (exceptuándose, evidentemente, aquellos contratos manchados por algún vicio de la voluntad), celebra un contrato admitiendo y reconociendo, de antemano, que el mismo le es excesivamente oneroso. Normalmente, dentro de un concepto promedio de buena fe $\mathrm{y}$ razonabilidad, que debe estar presente en cualquier tipo o modelo de contrato, el contratante busca, siempre, visualizar una equivalencia de prestaciones.

Si alguien compra un automóvil en prestaciones / cuotas (pago mensual de cierto valor a una institución financiera o banco, por ejemplo), busca abonar el precio justo, de mercado (prestación / cuota con los cargos previamente ajustados). Ningún 
contratante promedio, dentro de las reglas de la experiencia común, desde luego, busca asumir una prestación desproporcional, que pueda llevarlo a la ruina.

Esta idea de proporcionalidad y de equivalencia material de las prestaciones, siempre derivó del entendimiento promedio de las personas, puesto que, reiterando, nadie contrata para asumir, deliberadamente, un perjuicio, traducido en una potencial prestación desproporcional. ${ }^{97}$.

97 El principio da equivalencia de las prestaciones (prestación y su retribución o contrapartida) es, claramente, inherente e indisociable de cualquier contrato sinalagmático, cuya idea deriva hasta de las más elementales y primarias reglas de la experiencia común. Su no observancia puede llevar - lo que normalmente sucede - a lo que la tradicional doctrina alemana denomina como "distorsión de equivalencia" (“äquivalenzstorung”). La misma justifica, bajo ciertas condiciones, merced a la sobreviniencia de graves distorsiones que afectan de sobremanera la base del negocio originario, la necesidad de adaptación del acuerdo a las nuevas circunstancias. Constátese aquí, como norma de referencia, el art. 313 del BGB, verbis: "Alteración de la base del negocio: 1. Si con posterioridad a la celebración del contrato se han modificado de modo substancial las circunstancias que han devenido la base del contrato y, de haber previsto esta modificación, las partes no hubieran celebrado el contrato o lo hubieran celebrado con otro contenido, puede exigirse la adaptación del contrato en la medida en que no pueda exigirse a una parte el mantenimiento del contrato no modificado, teniendo en cuenta todas las circunstancias del caso concreto, especialmente la distribución legal contractual del riesgo. Se equipara a una modificación de las circunstancias el hecho que presupuestos esenciales, que han devenido la base del contrato resultan ser falsos.3.Si no es posible o no es exigible a una parte una adaptación do contrato, la parte perjudicada puede resolver el contrato, Para relaciones obligatorias continuada, en lugar del derecho de recisión rige el derecho de denuncia." 
Este ideario de reciprocidad no es reciente, como se puede observar, por ejemplo, en la obra universal de WILLIAM SHAKESPEARE, en su mundialmente conocida obra de teatro. $^{98}$

"Espere un poco, que hay una cosa más.

La multa no le da derecho a sangre;

Una libra de carne es la expresión: cobre la multa, coja su carne.

Pero si, al cortar, cae una sola gota de esa sangre cristiana, su patrimonio por las leyes de Venecia es confiscado, retorna al Estado."

Como consecuencia de este elenco de valores, es razonable sustentar que la equivalencia de las prestaciones es una de las vertientes de lo justo, idea esta que llevó al filósofo griego

${ }^{98}$ Se hace referencia al exacto momento en que Porcia sentencia la lid entre el perverso usurero Shyloch y el pobre Antonio. (SHAKESPEARE, W., "O mercador de Veneza”, Lacerda, Río de Janeiro, 1999.] 
ARISTÓTELES a sustentar, en una máxima siempre repetida a través de los tiempos, que "lo justo es una de las especies del género proporcional."99

En el ambiente jurídico, esa proporcionalidad y equivalencia siempre fueron valorizadas por la mejor doctrina, destacándose, "verbi gratia", la interpretación autorizada de RICARDO LUIS LORENZETTI que, con maestría ejemplar, preconizó que "lo que debemos aislar es el componente relativo a la correspectividad objetiva de las prestaciones que se mantiene de una fundamental importancia en los contratos discrecionales para juzgar el equilibrio, la reciprocidad, la conmutatividad entre lo que da y entrega cada parte en el momento de celebrar el contrato y a lo largo de su desarrollo, y fundamenta la excepción de incumplimiento contractual, el pacto comisorio y la excesiva onerosidad sobreviniente" 100

Por su parte, E. BETTI, ilustre catedrático de la Universidad de Roma, a ese respecto, aunque veladamente acabe por dejar de lado los criterios de calibración y modulación propuestos por OSTI Y OERTMANN, mantiene que la tormentosa y

99 ARISTÓTELES, “Ética a Nicômacos”, UNB, traducción de Mário da Gama Cury, 2001, p.96.

100 LORENZETTI, R.L., “Redes contractuales conceptualización jurídica, relaciones internas de elaboración, efectos frente a terceros”. Revista de Direito do Consumidor, São Paulo, $n^{0} 28 / 30$. 
conflictiva cuestión de la proporcionalidad, siempre deseada y querida por las partes contratantes, pasa por la adopción de los criterios de equidad como forma de distribuir los riesgos del contrato, de la mejor manera posible: "podemos decir que la 'ratio iuris' del remedio a una excesiva onerosidad no se debe buscar ni en una 'voluntad marginal', ni en la 'base del negocio', ni en el solo elemento causal del negocio, sino más bien en la condición de conservar el coste inicial de la prestación, que responde a la exigencia de equidad en la cooperación entre deudor y acreedor en cuanto a la distribución de los riesgos que exceden del alea normal del contrato.” 101

En este estado, y teniendo en vista todo el temario, la eventual ausencia, principalmente sobreviniente, del equilibrio querido originariamente por las partes, ciertamente tiene la cualidad de desvirtuar aquello que fue deseado por los sujetos contratantes en el momento del ajuste o, para utilizar la acertada expresión acuñada por el doctor y profesor LORENZETTI, inexistencia, por hecho sobreviniente, del componente relativo a la correspondencia objetiva de las prestaciones, con ausencia del elemento genético y funcional del contrato.

Por lo tanto, la ecuación a ser enfrentada seguidamente, nos dice respecto a la construcción y ulterior análisis y algunos criterios que puedan permitir, válidamente, la revisión de lo que fue originariamente contratado, a fin de restablecer la economía del

101 BETTI, E., “Teoria general de las obligaciones”, traducción por José Luiz de Los Mozos, Tomo I, Revista de Derecho Privado, Madrid, p.221. 


\section{Alteración de las Circunstancias y Revisión Contractual}

contrato de forma equitativa, con la consecuente flexibilización válida del principio de la cláusula "pacta sunt servanda."102 103

102 Es importante dejar consignado que la invocación de la alteración de las circunstancias, por hecho sobreviniente, no tiene relación alguna con el eventual error que pueda ser cometido por uno de los contratantes, al momento de la ultimación del contrato, en la medida en que, conforme con correcta e eminente doctrina, el error dice respecto a la naturaleza del acto, al objeto principal de la declaración o a algunas cualidades esenciales a él. Estas situaciones, cuando confirmadas, generan la consecuencia de considerar a la conducta del contratante como defecto viciante de su voluntad. Difiere, por lo tanto, "prima facie", substancialmente, de la posibilidad de surgimiento de alteraciones excepcionales ulteriores en la vida del contrato. En suma, el error se constituye en una opinión equivocada sobre las condiciones fundamentales y determinantes para manifestación de la voluntad del contratante, cuyas consecuencias ulteriores no son realmente buscadas por el mismo (lección ejemplar de CAIO MÁRIO, “Instituições de Direito Civil”, Saraiva, columna I, pp. 519-520).

${ }^{103}$ Tampoco hay que confundirse aquí con el instituto jurídico de la lesión, ya que ésta $\underline{\text { nace, }}$ primitivamente hablando, con el propio contrato, haciéndose pasible de cuestionamiento por este específico motivo. Difiere, por lo tanto, prima facie, de la alteración de las circunstancias, que obviamente presupone un contrato válido, pero con posterior desequilibrio de su economía. En la senda autorizada de FRANCESCO MESSINEO, éste, comentando el Código Civil Italiano expresa que, “...c) Son también distintos entre si los presupuestos de la rescisión por lesión (art. 1448) y de la resolución por excesiva onerosidad (art.1467), aunque en ambos casos se trate de una desproporción entre las prestaciones. La primera (véase retro, Cap. XIV, nº 10) implica un desequilibrio inicial entre las prestaciones; la segunda, un desequilibrio sobreviniente (véase supra, $\mathrm{n}^{\circ} .14$ ). Para la primera es necesario que la parte haya obtenido provecho del estado de necesidad de la contraparte en el momento de la conclusión del contrato; para la segunda, tal requisito es necesario porque, sobre todo, está fuera de las 'posibilidades que una parte obtenga provecho de la excesiva onerosidad por lo que cuando ésta se verifica, el contrato ya ha sido concluido." (MESSINEO, F., "Doctrina 


\subsection{La cláusula "hardship": concepto y aplicabilidad}

Históricamente, el derecho privado siempre se asentó en la clásica y antigua dicotomía entre Derecho Civil y Derecho Mercantil (hoy también denominado Empresarial, merced a la fuerte contribución de la moderna doctrina italiana, de mediados del siglo XX, con el surgimiento del Código Civil Italiano de 1942). Ello debido a que, tanto el Derecho Civil, como el Derecho Mercantil/Empresarial, a pesar de estar albergados en el mismo tronco (Derecho Privado), surgieron, cada uno, de modo manifiestamente diferenciado.

El Derecho Civil, como es notorio, especialmente aquél profesado en el continente europeo y en América Latina, tiene como segura matriz al clásico y conservador Derecho Romano. Por su parte, el Derecho Mercantil, en su esencia más elástico y flexible, derivó, fundamentalmente, de una nueva concepción económica del mundo instituida en la Edad Media, cuando tras la caída del Imperio Romano, sobrevino, sobre todo en Europa continental, una nueva clase (segmento) de personas, representadas, básicamente, por los mercaderes, pequeños comerciantes y artesanos.

General del Contrato”, traducción de R. O. Fontanarrosa, Sentis Melendo y M. Volterre, Tomo II, Ediciones Jurídicas Europa - América, Buenos Aires, 1986). 
Este nuevo segmento social, con nuevos actores económicos, fue responsable, en definitiva, por la creación - debido a la necesidad de tutela de sus intereses económicos mediatos e inmediatos - de un nuevo derecho, capaz de proteger sus aspiraciones con un mínimo de seguridad jurídica. De esta forma, las incipientes relaciones comerciales dentro de este nuevo orden, que pasaron a ser configuradas en Europa Occidental después de la caída del Imperio Romano, muestran el surgimiento, en un primer momento, de un derecho plasmado en base a las costumbres comerciales por entonces practicadas, cuyo concepto (Derecho Consuetudinario Mercantil) sirvió de base y fundamento para la denominada "lex mercatoria".

La denominada Ley de los Mercaderes fue, y continúa siendo, vastamente utilizada en la solución de controversias relativas a contratos en general, especialmente contratos internacionales, que gravitan alrededor del Derecho Internacional Privado. Aunque, en la actualidad, haya perdido cierta fuerza en la solución de conflictos jurídicos domésticos (ya que en este contexto, normalmente, son aplicadas las reglas del derecho positivo existentes en los respectivos ordenamientos jurídicos de los países que adoptan la tradición romanista), en el ámbito del comercio internacional globalizado la referida "lex mercatoria" aún representa la mejor alternativa para la solución satisfactoria de las controversias en contratos de naturaleza internacional, en especial aquellos caracterizados como de tracto diferido o sucesivo.

Ello porque los antiguos comerciantes (hoy empresarios) siempre adoptaron una práctica jurídica notoriamente 
desvinculada de cierta rigidez y conservadorismo propios del Derecho Romano. La idea de que "time is money" siempre estuvo presente en el sentido común de los comerciantes contratantes a través de los tiempos y en todo lugar. Eso es un hecho no susceptible de controversias.

En el intrincado ambiente de los contratos internacionales las dos grandes discusiones iniciales, siempre llevadas a cabo por los contratantes, se circunscriben a la ley aplicable y a la jurisdicción, teniendo como telón de fondo la idea - que no puede ser dejada de lado - de la minimización de los riesgos propios del contrato.

No obstante, aunque las partes, después de largas discusiones, establezcan las reglas y premisas básicas relativas a la ley aplicable y jurisdicción competente (mayores problemas de los contratos internacionales), siempre se hace presente la cuestión residual (pero no de menor importancia) de la forma a través de la cual las partes ejecutarán el contrato y como se comportarán en la hipótesis de la alteración de las circunstancias por algún hecho sobreviniente.

Dicho de otro modo, hasta surge de la intuición (porque deriva de las más elementales reglas ordinarias de la experiencia común) que los contratos internacionales, de larga duración, se exponen, de forma natural, a eventuales situaciones imprevisibles (de cualquier carácter y que escapan del alea natural del contrato) que, como es sabido, son inherentes a cualquier contrato de ejecución continuada o diferida, sean éstos domésticos o internacionales. 
Además, abriendo un pequeño, pero significativo paréntesis, la idea de la alteración de las circunstancias es un concepto inherente a cualquier contrato de larga duración. Más aún: los contratantes, en tales casos, deben partir de la premisa de que es absolutamente posible el surgimiento de una situación imprevisible, sea ésta de mayor o menor intensidad.

Los empresarios internacionales, a causa de los riesgos naturales que siempre existen en todo y cualquier contrato, ya se dieron cuenta del cambio actualmente existente en relación a las premisas básicas de los contratos de larga duración: la imprevisibilidad deja de ser excepción para representar una situación concreta de que el contrato firmado podrá no ser cumplido (total o parcialmente), merced al aumento natural y significativo de los riesgos anormales que gravitan alrededor de cualquier convenio de carácter internacional.

Esos riesgos son agudizados cuando se instala una controversia, por causa del incumplimiento del contrato, en la modalidad de alteración de las circunstancias. Aunque las partes contratantes, en el comienzo de la elaboración del pacto respectivo hayan elegido, por libre convicción, la ley aplicable y la jurisdicción respectiva, es forzoso concluir que la solución efectiva del problema (solución satisfactoria de la controversia) migrará hacia otro espacio (el judicial), con la aplicación de un sistema normativo que, muchas veces, no contempla, concretamente, el instituto de la revisión contractual por la alteración de las 
circunstancias (el actual sistema jurídico español es claro ejemplo de ello: no hay, en el ordenamiento positivo, norma expresa que permita la revisión contractual por la alteración de las circunstancias, como se da en, por ejemplo, los sistemas germánico, italiano, portugués y brasileño). ${ }^{104}$

En este orden conceptual, es que fue concebida la cláusula de "hardship", que trae en su esencia la idea de una situación difícil de soportar, algo como una flagrante y notoria adversidad. En dicho sentido, tal cláusula, cuando es insertada en el contrato, genera la posibilidad de que las partes renegocien las bases económicas del mismo, de forma que busquen, en última instancia, una nueva organización económica de lo que fue anteriormente pactado, teniendo en cuenta, concretamente, el rescate del equilibrio económico del acuerdo, de manera que se salvaguarde, en la secuencia, el equilibrio necesario en la ejecución del referido contrato.

Según las prolíficas enseñanzas de CARVALHO FERNANDES, profesor de la Facultad de Derecho de la Universidad Católica Portuguesa, al referirse a las denominadas "hardships clauses", expresa sabiamente que "las cláusulas de renegociación designación que preferimos a las de 'hardship clauses' - son estipulaciones negociales que imponen a las partes la obligación de renegociar un contrato siempre que, por efecto de una alteración de las circunstancias vigentes a

\footnotetext{
104 A este respecto, ver, también, comunicación por nosotros presentada em el I Congreso de Derecho Comercial, São Paulo, Brasil, 2011, "A alteração das circunstâncias nos contratos empresariais e a cláusula "hardship", ALMEIDA FERNANDES, R.
} 
tiempo de su celebración, se verifica una modificación substancial del equilibrio de las posiciones establecido por las partes.

Continuando su agudo razonamiento, CARVALHO FERNANDES sustenta, seguidamente, que "se trata, pues, de un instrumento jurídico más - de fuente negocial - que tiene por objetivo dejar de lado los efectos que, en los contratos que perduran en el tiempo, derivan de eventos verificados posteriormente a su celebración y se proyectan de modo significativo en la economía del negocio. El recurso a este tipo clausular que, por las razones particulares mencionadas, surge como relevo en los contratos internacionales, permite encontrar soluciones más ajustadas a las particularidades del acuerdo en cuyo contenido se incluyen. En realidad, cuando la estipulación en ellas contenida gane efectividad, por el acuerdo de las partes en relación a la modificación del contrato, ésta ha de ser, en la normalidad de los casos, más satisfactoria que la alcanzada por la vía judicial, aunque el juez realice una ponderada aplicación de la equidad." 105

También en el sentido de mejor conceptualizar la correcta y certera extensión de la cláusula de "hardship", es importante considerar lo expresado por el jurista y profesor brasileño SILVA MELO que, sobre tan instigante tema, aduce que tal cláusula, para a su aplicabilidad, alberga la idea de "una situación en que la alteración de factores políticos, económicos, financieros, legales o incluso tecnológicos

105 CARVALHO FERNANDES, “A teoria da imprevisão no direito civil português", Quid Juris, Lisboa, 2003, p. 315. 
que regían en la época de celebración del contrato tenga como resultado consecuencias dañosas para una de las partes. Tales modificaciones pueden ser causadas por fenómenos geofísicos, por las condiciones socioeconómicas vigentes en el sistema internacional o también por las alteraciones en el mercado internacional, derivadas de crisis estructurales, escasez, fluctuaciones de precios, etc., con respectivas consecuencias en la política comercial, como restricciones, medidas y proteccionismo, entre otras."106

Siguiendo esta misma dirección ORLANDO GOMES, conocido jurista brasileño, sustenta, con mucha propiedad, que es "una cláusula que permite la revisión del contrato si sobrevienen circunstancias que alteren substancialmente el equilibrio primitivo de las obligaciones de las partes. No se trata de una aplicación especial de la teoría de la imprevisión a la cual algunos quieren reconducir la referida cláusula. Se trata de nueva técnica para encontrar una adecuada reacción para con los hechos sobrevivientes que alteren la economía de las partes, para mantener (...) bajo el control de las partes, una serie de controversias potenciales a fin de asegurar la continuación de la relación en circunstancias que, según los esquemas jurídicos tradicionales, podrían llevar a la resolución del contrato."107

106 SILVA MELO, “Contratos internacionais e cláusula de hardship”, Aduaneiras, São Paulo, 2000.

${ }^{107}$ GOMES, O., parecer jurídico obrante en el texto "Dos contratos internacionais: uma visão teórica e prática”, de Luiz Olavo Batista, Saraiva, São Paulo, 1994, pp.143/144, 
En consecuencia, debido a la siempre imperiosa necesidad de garantizarse el equilibrio contractual inicial, fue contemplada en los principios del UNIDROIT (International Institute for the Unification of Private Law, organización intergubernamental independiente, fundada en 1926, con sede en Roma, Italia), la posibilidad de armonizar las contradicciones eventuales derivadas de la alteración de las circunstancias con el restablecimiento del equilibrio contractual originario, teniendo en vista el artículo 6.2.2 $2^{108}$.

Del enunciado transcripto en la nota de pie de página, se extraen, como puntos fundamentales, que teniendo como norte el concepto central del "caput" de la disposición citada, en el sentido del surgimiento de acontecimientos que alteran, durante la vida del contrato, substancialmente, el equilibrio de las prestaciones: a) existe "hardship" cuando surgen acontecimientos sobrevinientes a posteriori de la conclusión del contrato, o que solamente fueron conocidos por el contratante perjudicado después de la conclusión del mismo; b) se da "hardship" cuando, probadamente, el contratante perjudicado no pudo, razonablemente, posteriormente a la conclusión del contrato, vislumbrar ni

108 Como ilustración, sigue el texto original e integral del dispositivo de marras, "in verbis": "Définition - Il y hardship lorsque suviennent dês événements qui altérent fondamentalement l'équilibre dês prestations, soit que le coût de l'exécution dês obligations ait diminué, et a) eu ces événements sont survenus ou ont été connus de la partie lésée aprés la conclusion du contrat; b) que la partie lésée n’a pu, lors de la conclusion du contrat raisonnablement pendre de tel événements en considération; $c$ ) que ces événements échappent au controle de la partie lésée; et d) que le risque de ces événements n'a pás été assume par la partie lésée”. 
antever la sobreviniencia de los acontecimientos imprevisibles en cuestión, siendo necesario, también, que tales sucesos escapen al control del contratante perjudicado $\mathrm{y}$, finalmente, c) nos encontramos ante la mencionada "hardship" cuando el riesgo de esos acontecimientos no sea efectivamente asumido por la parte perjudicada $y$, finalmente, d) que el riesgo de esos acontecimentos no sean efectivamente asumidos por la parte perjudicada.

De todo lo expresado, y analizándose puntualmente las directrices constantes en la citada disposición 6.2.2, se constata, la normatización (o tentativa) de las posibilidades que podrán justificar la revisión contractual por los propios firmantes originarios, por la senda de la renegociación necesaria, de manera que restablezcan los elementos económico-financieros que llevaron a las partes a implementar el negocio originario.

No se debe perder de vista, en el mismo sentido, como otro significativo ejemplo, las directrices sobre el tema emanadas de la Convención de Viena sobre la venta internacional de mercaderías (1980), donde en su art. 79, se alberga la idea de posibilidad de incumplimiento de la obligación por parte de uno de los contratantes siempre que quede acreditado el nacimiento de un hecho sobreviniente, impeditivo de la eficaz ejecución de la prestación debida y ajeno a la voluntad de las partes, "in verbis": "una parte no es responsable por la inejecución de cualquiera de sus obligaciones si prueba que tal hecho se debió a un impedimento ajeno a su voluntad y que no era razonable esperar 
que ella lo considerase en el momento de la conclusión del contrato, lo previese o lo traspasase o que previese o traspasase sus consecuencias."

Evidentemente, la inclusión de la cláusula de "hardship", en cualquier contrato nacional o internacional, con imposición de la necesaria renegociación, se fundamenta, obviamente, en la plena autonomía de la voluntad, tan sólo con la diferencia de que los mismos contratantes, en la elaboración del instrumento, prudentemente, previeron la posibilidad del surgimiento de una situación de carácter imprevisible, capaz, por sí sola, de informar un aumento significativo de la obligación pactada. A fin de cuentas, no podría ser de otra forma, teniendo en cuenta la excelsa frase del genio pionero de JEAN DOMAT, en el sentido de que "quien se obliga sólo quiere lo menos."

Está claro que no debe confundirse el derecho a la pretensión de la renegociación con el derecho absoluto de exigirse, de la contraparte, la inmediata sumisión al nuevo formato contractual, ciertamente sugerido por el contratante perjudicado por las nuevas circunstancias. Una cosa es la renegociación con base en la potencial y sugerida (obviamente por el contratante perjudicado) existencia de la alteración de las circunstancias, capaz de acreditar el cambio de la economía del contrato; y otra cosa bien diferente es la prueba efectiva de la existencia de la alteración mencionada, de modo que exija de la otra parte una nueva organización económica del acuerdo. 
$\mathrm{Si}$ las partes vinculadas a través del contrato, consensualmente, entienden que hay necesidad de una nueva organización contractual, la controversia estará superada por un nuevo acuerdo de voluntades. Sin embargo, caso no haya consenso en la reorganización económica del instrumento, en la esfera extrajudicial, el contratante que carga con el perjuicio deberá buscar el restablecimiento del equilibrio contractual deseado por la vía judicial (cuya materia es tratada, en este trabajo en capítulo diferente) o con la solicitud para la instalación de eventual juicio arbitral, en el caso en que esa hipótesis haya sido, en el acuerdo, originariamente contemplada por las partes. 


\section{CAPÍtulo IV}

1. Principales soluciones propuestas por la doctrina a lo largo del tiempo: Teoría de la Presuposición, Teoría del Hecho Sobreviniente y Teoría de la Base del Negocio Jurídico.

\subsection{Teoría de la Presuposición}

\subsection{Teoría del Hecho Sobreviniente}

1.3. Teoría de la Base del Negocio Jurídico

1.4. Puntos comunes parciales

2. Criterios objetivos para la aplicación de la Teoría de la Imprevisión (la cuestión de la excesiva onerosidad, frustración de la finalidad del contrato y desaparecimiento de la base del negocio)

3. Efectos jurídicos de la revisión judicial o de la resolución del contrato

3.1. De la posibilidad de utilización de acción cautelar por el contratante en desventaja 


\section{PRINCIPALES SOLUCIONES PROPUESTAS POR LA DOCTRINA A LO LARGO DEL TIEMPO: TEORÍA DE LA PRESUPOSICIÓN, TEORÍA DEL HECHO SOBREVINIENTE Y TEORÍA DE LA BASE DEL NEGOCIO JURÍDICO}

\subsection{Teoría de la Presuposición}

\subsection{Teoría del Hecho Sobreviniente}

\subsection{Teoría de la Base del Negocio Jurídico}

\subsection{Puntos comunes parciales}

Según fue expuesto anteriormente, la nueva situación jurídica, en la posguerra (comienzos de la década del veinte del siglo pasado), volvió a atraer la atención de los doctrinarios y jueces, que buscaron presentar, al mundo jurídico, teorías que pudiesen dar el necesario soporte científico a la nueva situación, explicando (o intentando explicar) la naturaleza jurídica de la teoría de la imprevisión con el propósito de separarse de las intensas motivaciones religiosas o filosóficas que consagraron, inicialmente, en otro momento histórico, la Teoría de la Imprevisión.

Esa preocupación candente, no dejó de ser notada, por ejemplo, por P. ROMANO MARTINEZ, notable jurista de 
la Facultad de Derecho de Lisboa y de la Universidad Católica, que escribió, con gran sabiduría, que "con la alteración de las circunstancias se establece un enfrentamiento entre la estabilidad y la seguridad jurídica, por un lado, y la justicia conmutativa, por el otro; en diferente plano, se dirá que existe una contraposición entre la autonomía de las partes y la buena fe. De hecho, en ciertos casos, se admite la licitud del no cumplimiento de cierta prestación emergente de un contrato porque las alteraciones surgidas en el ínterin hacen inicua esa exigencia. La cuestión no es reciente, habiendo suscitado polémica en torno de diversas teorías que justifican la no subsistencia del contrato en los términos pactados y convenidos, desde la cláusula "rebus sic stantibus", hasta las teorías de la presuposición, de la base del negocio y de la imprevisión, llegando a la consagración del instituto en el art. 437 del Código Civil Portugués." 109

\subsection{Teoría de la Presuposición}

Es un hecho que, ya en el siglo XIX, algunos doctrinarios demostraban una preocupación científico-académica en relación al tema. Uno de los primeros doctrinarios europeos que profundizó sobre el intrincado tema, con el objetivo de justificar, en una

\footnotetext{
109 ROMANO MARTINEZ, P., “Da cessação do contrato”, $2^{\mathrm{a}}$ edición, Almedina, p. 157
} 
interpretación final, el quiebre de la fe jurada, base de la cláusula "pacta sunt servanda", fue el célebre y erudito comentador de las "pandectas" (los llamados pandectistas, como es sabido, eran los doctrinarios que comentaban las susodichas "pandectas", derivadas del trabajo de compilación y conciliación de las decisiones de los antiguos jurisconsultos romanos, a las cuales Justiniano dio fuerza de ley) y prestigioso jurista alemán BERNARD WINDSCHEID, ${ }^{110} / 11$ que concibió, en 1850, la llamada Teoría de la Presuposición (“Voraussetzung”).

Citando las palabras del ilustre WINDSCHEID, "quien manifiesta un deseo bajo una presuposición quiere, como quien emite una declaración de voluntad condicionada, que el efecto jurídico solamente exista dado un cierto estado de relaciones; pero no alcanza hasta el hecho de hacer depender de ello la existencia de la relación. La consecuencia de lo expuesto es que el efecto jurídico subsiste y perdura, aunque venga a menos que la presuposición. Sin embargo, eso, lo que quiere en realidad es apenas la subsistencia del efecto jurídico del autor de la declaración de voluntad. Como fruto de antedicho, podemos sostener que la subsistencia mencionada, no obstante estar justificada de manera formal, no lo está substancialmente, por carecer de esa razón intrínseca. Como efecto de ello, aquél que es perjudicado por la declaración de

${ }^{110}$ Die lehre des römischen rechts vou der voraussetzung. Verlagsbuchhandlung von Julius Buddeus, Düsseldorf, 1850.

111 Ver, también, a este respecto, la postura de ANTONIO LOMBARDI, “La Rizoluzione per Impossibilità Sopraventa - la Presupposizione: protili generali”, Giceffré, Roma, 2007, pp. 353/354. 
voluntad puede defenderse por medio de excepciones contra las razones que se derivan de ella. Además de poder accionar contra quien se haya beneficiado por el efecto jurídico y para detener el mismo. Como con la condición, la circunstancia, a la que la presuposición se refiere, puede ser de hecho o de derecho, positiva o negativa, pasada, presente o futura; esta antítesis no da lugar a una diversidad de tratamiento legal." 112

KARL LARENZ, excepcional y notable doctrinario germánico, sobre el asunto asevera que "la presuposición es, por consiguiente, una condición no desenvuelta y, al igual que la condición típica, una 'autolimitación de la voluntad', no de la voluntad efectiva, consciente, sino de la voluntad verdadera."

Con elegante pedagogía y discurriendo, también, sobre la apasionante teoría, el jurista portugués CUNHA GONÇALVES expresa que "se llama presuposición o presupuesto a una cláusula que puede ser expresa, pero que en la mayoría de los casos está implícita o no declarada - cláusula que no debe confundirse con condición tácita - y que, aunque sea un elemento accesorio del contrato, como la condición propiamente dicha, difiere de ésta en que, o no es parte de la

${ }^{112}$ WINDSCHEID, “Diritto delle Pandette”, traducción de Carlo Fadda y Paolo Emílio Bensa, Unione Tipografico -Editrice Torinese - UTET, Turín, 1902.

113 KARL LARENZ, “Base del negócio jurídico y cumplimento de los contratos”, traducción de Fernandez Rodriguez, Revista de Derecho Privado, Madrid, 1956, p.23. 
declaración de voluntad, o no suspende el negocio jurídico ni lo hace incierto".

Siguiendo ese razonamiento, el preclaro maestro lusitano mencionado, nos brinda el siguiente ejemplo: "Pedro, con una hija a punto de contraer matrimonio, tomó en carácter de arrendamiento una casa para los futuros cónyuges; sin embargo, por motivo imprevisto o imprevisible, el casamiento no puede realizarse, ni tampoco tendrá lugar en el futuro. Este proyecto era, por lo tanto, la presuposición del arrendamiento; pero, no habiendo sido declarado como condición suspensiva, ¿cuál será el destino del mismo? ¿Podrá el locatario pretender la rescisión del contrato, alegando la cesación del objeto que lo provocara? Y el locador, por su parte, teniendo conocimiento de este fin, ¿deberá sujetarse a la rescisión, recibiendo una equitativa reparación? En la compraventa, constituye también una presuposición la circunstancia de que la mercadería vendida está libre de vicios ocultos; por lo cual, descubriéndose alguno, el vendedor es obligado a sustituirla por otra que esté en armonía con tal presuposición".

Para concluir, con su gran saber y profundidad, CUNHA GONÇALVES expresa que "esta cláusula implícita se confunde con el motivo del contrato. Sin embargo, mientras que el motivo es cualquier representación psíquica interna, el presupuesto debe poseer el requisito de la cognoscibilidad externa; es decir, debe poder ser considerado o reconocido por las partes como un elemento tan importante y 
necesario, según las reglas de la buena fe y los usos comerciales, que sin él la declaración de la voluntad no se habría realizado."114

Con otras palabras, pero adoptando el mismo entendimiento exegético, el ilustre jurista lusitano J. de ALMEIDA COSTA, insigne profesor catedrático de la Facultad de Derecho de la Universidad de Coimbra, asevera que "cualquier declaración de voluntad negocial puede ser realizada con la plena convicción de que se mantendrá determinado estado de cosas al tiempo existente, o de haberse producido o venir a producirse ciertos hechos pretéritos, presentes o futuros, de tal forma que, de otro modo, no se realizaría el negocio, o su estipulación habría ocurrido bajo otros términos; y el convencimiento de la verificación de esas circunstancias o hecho es tan seguro, que ni siquiera se expresa en el contrato la cláusula correspondiente, presentándose la presuposición, por lo tanto, como una condición embrionaria, o no explicitada o desarrollada (eine entwickelte Bedingung). Se denomina presuposición (Voraussetzung) a la circunstancia o situación presupuesta y al propio estado de espíritu del presuponente." 115

En la misma senda de interpretación del referido estudio, la elaboración de PAULO CUNHA, profesor de la

114 CUNHA GONÇALVES, "Tratado de Direito Civil”, en Comentário do Código Civil Português, Vol. IV, Editorial Coimbra, Coimbra, 1932, p. 416.

115 DE ALMEIDA COSTA, J., "Direito das Obrigações", 4 edición, Editorial Coimbra, Coimbra, 1984, p. 216. 
Facultad de Derecho de la Universidad de Lisboa, enriquece el debate para la correcta comprensión de la teoría en análisis, consignando lo siguiente: “(...) así, tenemos que considerar una segunda modalidad doctrinaria: por vía de la teoría de la presuposición. Dicen quienes así entienden que no hay duda que, en principio, para el deudor librarse de la responsabilidad sobre él recaída por el no cumplimiento, es necesario, mientras exista la obligación, que haya sido impedido absolutamente de cumplir; sin embargo, agregan, la verdad es que los negocios jurídicos son realizados bajo la presuposición de que el condicionalismo económico de la operación se mantiene."

Finalizando su sesuda interpretación, el citado autor afirma que "por lo tanto, cuando esa base falla, y existe una alteración radical de las condiciones de la operación - alteración esta no prevista concretamente por las partes, que de haberse previsto, con seguridad habría sido óbice a que contrataran - desaparece la presuposición que era causa del propio contrato. Dicho de otro modo, la onerosidad excesiva de la prestación, resultante del cambio de las condiciones económicas que rodean cierto contrato, no tiene el alcance directo de dispensar al deudor del cumplimiento, pero sí tiene el alcance indirecto de determinar o la rescisión o la revisión del contrato, bajo los términos generales de la teoría de la presuposición. Finalmente se llega al mismo resultado de una forma transversal: por la vía de atacar la propia subsistencia del contrato. No se ataca de frente la cuestión de la responsabilidad, pero sí el propio hecho jurídico del cual la obligación emerge. Se reconoce que mientras la obligación esté en pie el deudor tiene responsabilidad, a menos que haya imposibilidad absoluta. Sin embargo, se sostiene que, cuando las condiciones económicas previstas varíen de tal 
modo que se configure una onerosidad excesiva de la prestación, es el propio contrato que queda minado (...).",116

Por su parte, el jurista brasileño PONTES DE MIRANDA, en su célebre obra Tratado de Direito Privado, expresa que "la teoría de la presuposición intentó mostrar que puede haber restricción de la voluntad negocial, de forma que, habiéndose admitido que exista, aparezca o persista determinada circunstancia, y que no se haya considerado como condición, la falla hace inadecuadas a la verdadera voluntad las consecuencias jurídicas." 117

Comentando el real alcance de tal teoría, el jurista brasileño J. M. OTHON SIDOU aduce, con objetividad inigualable, que "en todos los negocios jurídicos de ejecución diferida o continuada, hay, por parte de quien asume la obligación, el presupuesto tácito de que permanezcan constantes, o que no sufran sino las oscilaciones normales, las condiciones generales de mercado, el valor de la moneda, etc., y que, por lo tanto, sobreviniendo cambios extraordinarios, que hagan excesivamente gravosas las obligaciones contraídas, éstas puedan ser

\footnotetext{
${ }^{116}$ CUNHA, P., “Direito das Obrigações”, T.II, Imprensa Baroeth, Lisboa, 1939, p. 267.
}

117 PONTES DE MIRANDA, "Tratado de Direito Privado", parte especial, T. XXV, Borsoi, p.221. 
desconsideradas, ya que se subentiende en todo negocio jurídico de naturaleza patrimonial una cláusula "rebus sic stantibus". 118

En resumen, según tal teoría, siempre que alguien expresa su voluntad, lo hace con la certeza de la existencia del presupuesto de que las condiciones generales del valor, mercado y patrón monetario deben permanecer constantes e inmunes a cualquier alteración, durante la vida del contrato; es decir, inalteradas dentro de un patrón razonable de normalidad, susceptible de ser percibido, "prima facie", por el hombre medio.

Partiendo de la presuposición de que el estado de las cosas permanecerá inalterado, el contrato podrá ser revisto en caso de que haya un cambio extraordinario en la situación originaria (que dio oportunidad al pacto suscripto), que hace excesivamente oneroso para uno de los contratantes el cumplimiento de la prestación, y que causa, consecuentemente, un enriquecimiento ilícito para la otra parte contratante.

En otros términos, la presuposición infería una condición no desarrollada, o dicho de otro modo, una limitación de la voluntad que no se desarrolló suficientemente para convertirse en una condición. Tal teoría, a pesar de seductora, no logró el éxito esperado,

118 OTHON SIDOU, J.M., "Revisão judicial dos contratos e outras figuras jurídicas”, Forense, Río de Janeiro, 1984. 
siendo rechazada y repudiada por el Código Civil Alemán vigente en la época.

\subsection{Teoría del Hecho Sobreviniente}

Acompañando, en ciertos aspectos, la Teoría de la Presuposición, el jurista GIUSEPPE OSTI ${ }^{119}$, ya a comienzos del siglo XX, dio forma a la también conocida Teoría del Hecho Sobreviniente. Según este jurista italiano, al concebir su teoría del hecho sobreviniente (expresión utilizada como sinonimia de la teoría de la imprevisión), siempre que se formaliza un contrato de ejecución a término o de tracto sucesivo, existen dos momentos distintos: el de la declaración de la voluntad (momento presente) y el de la ejecución del contrato (momento futuro).

El primer momento exterioriza el deseo del contratante de asumir la obligación, mientras que el segundo, a su vez, corresponderá a la intención del contratante de cumplirla efectivamente, representando lo que el citado OSTI denominó "voluntad marginal" o determinación de voluntad.

119 OSTI, G., "Revisione critica della teoria sulla impossibilitá della prestazione", Riv.Dir. Civ., 1918. 
De acuerdo también con este eminente jurista italiano, para la exigibilidad plena de la obligación asumida, debe existir una conciliación de esos dos momentos fundamentales en la vida del contrato. Porque, siendo el contrato de ejecución a término o de tracto sucesivo, promesa para ser cumplida futuramente, el contratante, al celebrar el pacto, siempre proyecta la representación mental de sus efectos (determinación de voluntad), con el objeto de traducirla en actos de voluntad en la ocasión del cumplimiento del mismo.

Así pues, en la opinión de este doctrinario italiano, cabe distinguir entre la voluntad contractual y la voluntad para la efectiva realización de la prestación, determinante para la formación plena del contrato, pero que posee sobre sí, influyendo concretamente una voluntad voluntaria, valga la redundancia, voluntad voluntaria ulterior (voluntad marginal).

Comentando la inspiradora teoría de GIUSEPPE OSTI, el jurista argentino ROBERTO TELLO, en interesante explanación, sostiene que "Osti habla de la voluntad marginal. Al lado de la voluntad que podríamos llamar central, que se dirige a asumir una obligación, se encuentra la voluntad marginal correspondiente, o sea la voluntad de obligarse hasta cierto punto, que debe considerarse puesto que en ésta se encuentran implícitamente aceptadas las condiciones de ambiente económico y social en que el contrato se desenvuelve. El cambio de las 
circunstancias de hecho autoriza la rescisión o morigeración de los efectos del contrato de conformidad a esta voluntad marginal." 120

En este contexto, la voluntad marginal representaría el cumplimiento efectivo de lo acordado, tal como se presentó en el momento de la contratación, no siendo perfecta y definitiva mientras no se traduzca en ciertos actos. Ello da lugar, como consecuencia, a que eventos no previstos por las partes en el momento de la contratación puedan modificar aquello que fue originariamente ajustado.

Dicho de otro modo, tal teoría se sustenta, en definitiva, por la posibilidad de deshacerse el vínculo contractual asumido por la existencia de un hecho posterior, impeditivo de la verificación del resultado concreto estimado por el contratante promitente. Representa, como fuera señalado supra, la escisión de la voluntad de los contratantes en dos instantes distintos. Alterándose los hechos durante la ejecución del contrato, entiéndese ausente, como consecuencia, la propia voluntad contractual.

${ }^{120}$ TELLO, R., "La teoria de la imprevisión em los contratos de derecho público", Valerio Abeledo, 1946, Buenos Aires, pp. 87/88 


\subsection{Teoría de la Base del Negocio Jurídico}

Una tercera gran teoría sobre el asunto fue concebida por el jurista alemán P. OERTMANN ${ }^{121}$, en la década de los años veinte del siglo pasado, denominada Teoría de la Base del Negocio Jurídico ("Geschäftsgrundlage”) constituyéndose, según algunos doctrinarios, como una evolución y perfeccionamiento de la Teoría de la Presuposición, elaborada, como fue visto, por WINDSCHEID.

PAUL OERTMANN, refiriéndose al concepto de base del negocio, afirma que es "la representación mental de una de las partes en el momento de la conclusión del negocio jurídico, conocida en su totalidad y no rechazada por la otra parte, o la común representación de las diversas partes sobre la existencia o aparición de ciertas circunstancias, en las que se basa la voluntad negocial." 122

Esta teoría fue muy bien recibida por la doctrina alemana, destacándose, por ejemplo, la opinión de LUDWIG

121 "Die geschäftsgrundlage; ein neuer rechtshbegriff" (Base del negocio: un nuevo concepto jurídico). A Deichert'sche Verlagsbuchhandlung Dr. Werner.Scholl, Leipzigerlangen, 1921

122 OERTMANN, P., obra citada. 


\section{Alteración de las Circunstancias y Revisión Contractual}

ENNECCERUS, profesor de la Universidad de Marburg, Alemania, quien asegura que "en un nuevo estadio de la evolución, el derecho de resolución por alteración de las circunstancias fue fundado también en la desaparición de la base del negocio. Por base del negocio a estos efectos se han de entender las representaciones de los interesados, al tiempo de la conclusión del contrato, sobre la existencia de ciertas circunstancias básicas para su decisión, o en el caso de que estas representaciones no hayan sido conocidas meramente, sino constituidas, por ambas partes, en base del contrato, como, por ejemplo, la igualdad de valor, en principio, de prestación y contraprestación en los contratos bilaterales (equivalencia), la permanencia aproximada del precio convenido, la posibilidad de reponer la provisión de las mercancías y otras circunstancias semejantes. La fundamentación que se apoya en el defecto de la base del negocio, hace posible satisfacer la necesidad de un derecho de resolución no sólo en los casos en que las bases económicas del negocio han desaparecido en virtud de una alteración posterior de las circunstancias, sino también en aquellos en que de antemano esas bases no existían". ${ }^{123} 124$

123 ENNECCERUS, L., "Derecho de Obligaciones", traducción de Blas Pérez González y José Alguer de 35ª edición alemana, Vol. I, 1933, Bosch, Barcelona, p. 209.

124 Ver, también al respecto REINHARD ZIMMERMANN, citando vasta doctrina germánica coloca: "La expresión alemana Störung der Geschäftsgrundlage equivale a la frustración de la base del contrato. Igual que en el Derecho anterior a la reforma, la base del contrato consiste en las siguientes circunstancias: (i) las presupuestas por las partes en el momento de concluir el contrato, (ii) las que son tan importantes para una de ellas, que desde luego no hubiera concluido el contrato, o lo hubiera hecho con otras condiciones, si hubiera tenido conocimiento de las circunstancias que ahora se han producido, y (iii) aquellas que son de tal naturaleza que no pueda razonablemente esperarse que esta parte vaya a cumplir el contrato. Sobre el tema, ver Bundesminister 
Por su parte, MATTOS NETO, jurista brasileño, reflexionando respecto al asunto, con gran precisión, al comentar las enseñanzas de OERTMANN, aduce que "esta teoría relativamente bien aceptada por la doctrina, establece, en suma, en palabras más simples, que mientras persista la base del negocio, o sea, la coyuntura y circunstancias que autorizaron a las partes para formar su voluntad y manifestarla a través del contrato, las mismas se mantienen vinculadas a las estipulaciones ínsitas en el instrumento suscripto. Sin embargo, a partir del rompimiento de esta base negocial, la representación mental que da sustento a la voluntad negocial de las partes, no correspondería más a aquella del momento de la conclusión del negocio jurídico." 125

También en la misma línea, expresa PONTES DE MIRANDA ${ }^{126}$, que "en vez de la manifestación de la

de Justiz (Ed), Abschlußberitcht der Kommission zur Überarbeitung des Schuldrechts (1992), 146 ss.; P. Huber, en P. Huber y Faust (n $\left.{ }^{\circ} 18\right) 231$ ss.; Lorenz y Riehm ( $\left.{ }^{\circ} .18\right)$ 197 ss.; Anwaltkommentar/Krebs ( $\left.n^{\circ} 18\right) \S 313$, nn. 1 ss.; Günter H. Roth, en Münchener Kommentar zum Bürgerlichen Gesetzbuch, Vol II, $4^{a}$ edición, 2003, § 313; Astrid Stadler, em Othmar Jauernig (ed.), Bürgerliches Gesetzbuch, $11^{a}$ edición, 2004, § 313. - REINHARD ZIMMERMANN - "El nuevo derecho Alemán de obligaciones" traducción al castellano de Esther Arroyo y Amayeales, Bosch, Barcelona, 2008, pp. $49 / 50$.

125 MATTOS NETO, “A cláusula 'rebus sic stantibus' e a cláusula de escala móvel”, Revista de Direito Civil, Agrário e Empresarial, no 63, enero/junio de 1993, São Paulo.

${ }^{126}$ PONTES DE MIRANDA, obra citada, p. 222. 
voluntad que estaría en el negocio sin ser elemento de su todo, tal como sería la presuposición, P. OERTMANN pretendió dar el concepto de base o fundamento del negocio como representación mental de uno de los participantes del negocio jurídico en el momento de su conclusión, conocida y no rechazada por la otra parte, o la representación común de ambos en lo relativo a la existencia o aparición de ciertas circunstancias en que se basa la voluntad negocial".

Por lo tanto, tal modelo teórico preconiza que, mientras esté vigente la base del negocio emprendido, derivada fundamentalmente de la cláusula general de buena fe, y que representa, en la aguda explicación de PONTES DE MIRANDA, "el elemento circunstancial o estado general de cosas, cuya existencia o permanencia es esencial para que el contrato subsista, salvo donde el acuerdo de las partes restringió la relevancia del elemento o del estado general de las cosas"127, es que se levanta en el momento de la celebración del contrato, integralmente reconocido y no repudiado por la contraparte, el efectivo vínculo de los contratantes al mismo, hasta su ejecución total y extinción plena de los efectos jurídicos ulteriores de él provenientes.

Dicho de otro modo, la base del negocio comprende los condicionantes naturalmente presupuestos por las partes, representados por el conjunto de circunstancias vinculadas al propio negocio, cuya permanencia y persistencia debe ser razonablemente antevista por los contratantes para que se mantenga, en definitiva, el propio

${ }^{127}$ PONTES DE MIRANDA, “Tratado de Direito Privado”, parte especial, tomo XXV, Borsoi, Barcelona, p. 257. 
objetivo económico del contrato suscripto, con la pureza de su base negocial.

Así pues, el fundamento central, sucintamente, reposa en el entendimiento de que cuando un contratante exterioriza su voluntad, ésta, pasó necesariamente por la senda de la voluntad interna que es, nada más y nada menos, la intención (del latín "intentione", que significa propósito, deseo). La parte, por consiguiente, se hace una representación mental de su deseo, de forma que lo proyecta, ulteriormente, en el campo de la realidad.

No obstante, a posteriori, si esas representaciones se frustran, a causa de haber sido alcanzadas por hechos extraños a la voluntad de los contratantes, surgidos después de la conclusión del negocio, haciendo imposible su ejecución, las partes no pueden ser obligadas a cumplir aquello a que originariamente se comprometieron. Ello, porque no existiría más, llegado este punto, la base negocial (y su substrato objetivo, "atrincherado", como ya fuera dicho supra, en la cláusula general de buena fe), que las llevó (a las partes) a concluir el acuerdo instrumentado en el contrato.

En tal ambiente, según el citado $\mathrm{P}$. OERTMANN, el contrato no correspondería más a la originaria y primera voluntad de las partes, circunstancia que autorizaría la intervención por parte del Estado-juez para readaptar el pacto a aquella voluntad originaria, sea imponiendo un deshacer el vínculo contractual, por medio de acción 
propia, sea modificando, con la necesaria revisión, calibrando, también por medio de acción propia, el contrato respectivo, para que éste, efectivamente, venga a corresponder a lo que las partes tuvieron como objetivo en el momento pretérito de su celebración.

A final de cuentas, tal teoría tiene el mismo fundamento central que la teoría de la imprevisión, con base en la cláusula general de buena $\mathrm{fe}^{128}$, en la medida en que el factor imprevisible (entiéndase: factor imponderable, de carácter sobreviniente y no contemplado en la representación mental de los contratantes, informador de la ruptura de la base del negocio), cuando existente, tiene, siempre, el atributo de destruir la base del negocio originario, por la posterior frustración del fin económico contractual expresado en el propio contrato.

Por otro lado, buscando dar su respectivo valor a los pilares teóricos concebidos por PAUL OERTMANN, el jurista portugués, profesor de la Universidad Católica Portuguesa, CARVALHO FERNANDES, con un leve matiz de crítica, aduce que "siguiendo las propias palabras de OERTMANN, la base del negocio consiste en la representación de una parte, patente en la conclusión de un negocio y reconocido por la contraparte, de la existencia o de la

${ }^{128}$ A este respecto, según NELSON NERY JÚNIOR, la doctrina alemana es unívoca en afirmar que la teoría de la base del negocio tiene su origen en el principio de la buena fe objetiva. Véase, por ejemplo, en Zirker Matthias, Vertrag und Geschäftsgrundlage in der Zeit des Nationalsozialismus, Würzburg. Ergon Verlag, 1996, p.13.- Münster, Rechts-und Staatswissenschaftliche Fakultät, 1967. 
verificación futura de ciertas circunstancias sobre cuya base se sustenta la voluntad. Su afinidad con la teoría "windscheidiana” de la presuposición es manifiesta, poseyendo ésta un cariz claramente subjetivo, que desde temprano la condenaba al fracaso. Para ser relevante, en esta configuración subjetivista, la alteración de las circunstancias que cuestione la base negocial, debe tener su soporte en el propio negocio. Ahora bien, siendo la imprevisibilidad una de las características reconocidamente exigibles para que la alteración prospere - según esta concepción -, la voluntad de las partes, por sí misma, no podría constituir un fundamento sostenible del régimen jurídico que dispensa a uno de los contratantes del cumplimiento puntal de las obligaciones asumidas." 129

La mirada crítica de CARVALHO FERNANDES, al referirse a la construcción doctrinaria de PAUL OERTMANN como acogedora de contornos potencialmente subjetivos que dificultarían, en última instancia, su correcta aplicación a casos concretos en la actividad diaria de los litigantes, no tendría razón de ser, teniendo en cuenta el perfeccionamiento realizado por KARL LARENZ de la posición sostenida por su compatriota citado OERTMANN.

Según el aludido y eminente LARENZ, la concepción de la teoría de la base del negocio debe ser comprendida en dos sentidos que, en definitiva, terminan siendo complementarios, como los

\footnotetext{
${ }^{129}$ CARVALHO FERNANDES, “A Teoria da Imprevisão no Direito Civil Português”, Quid Júris?, Lisboa, 2001, p. 269.
} 
eslabones de la misma cadena: el sentido subjetivo y el sentido objetivo del negocio en sí (y de la propia voluntad entonces exteriorizada por los contratantes), establecido por las partes. El autor expresa que la base negocial subjetiva traduce "una determinada representación o expectativa segura, por parte de ambos contratantes, que fundamentó la celebración del contrato, y sin la cual no lo habrían celebrado, o no con aquel contenido, y sin la cual no sería honesto exigir su ejecución". Por otro lado, el mismo teórico germánico mantiene que la base negocial objetiva traduciría "aquellas circunstancias cuya ocurrencia o persistencia - aunque las partes no tengan conciencia de ello - sea presupuesta o postulada de acuerdo con el sentido del contrato" 130

Ahora bien, bajo estas consideraciones, el elemento subjetivo, en la concepción del nombrado LARENZ, pasa a estar íntimamente unido a la concreta motivación de la parte, en el sentido de la segura existencia de ciertas circunstancias que lo llevaron a contratar, siendo por ello, contrario a los dictámenes de la buena fe - materia exhaustivamente tratada en el capítulo anterior, y que debe estar siempre presente en todo y cualquier contrato - obligar al citado contratante a honrar el compromiso firmado, al no verificarse más la existencia de aquellas mismas circunstancias, sea de forma total o parcial.

Paralelamente a ello, en el campo de los aspectos comprobadamente objetivos, la base del negocio estaría indisolublemente relacionada a la idea - también siempre presente en

${ }^{130}$ LARENZ, K., “Allgemeiner Teil des deutschen burgerlichen Rechts”, 8 Aufl Beck, Munich, 1997, con Manfred Wolf. 
cualquier contrato - de garantizarse, en definitiva, el mantenimiento del vínculo contractual originario durante la vida del propio convenio y su objetivo final; o sea, el término del contrato de forma satisfactoria, sin frustración de su finalidad, de manera que no perjudique, de forma alguna, a los contratantes originarios.

El jurista brasileño NELSON NERY JUNIOR, analizando la extensión y correcta aplicación de la teoría de la base del negocio jurídico en el actual contexto histórico, conceptúa que "el negocio jurídico es celebrado sobre una base negocial, que contiene aspectos objetivos y subjetivos, base esta que debe mantenerse hasta la ejecución plena del contrato, como también hasta que sean extinguidos todos los efectos derivados del contrato (eficacia posterior). Por base del negocio deben entenderse todas las circunstancias fácticas y jurídicas que los contratantes tuvieron en cuenta al celebrar el contrato, que pueden ser vistas en sus aspectos subjetivo y objetivo." ${ }^{\prime 31}$

El aglutinante que termina por unir, necesariamente, los dos conceptos - subjetivo y objetivo - deriva, fundamentalmente, de la cláusula general de buena fe, que debe estar siempre presente en los contratos en general, como fuera expresad en otro capítulo. De esta forma, alteradas las circunstancias por el quiebre de la base negocial observamos que la doctrina alemana más moderna, en un creciente proceso de perfeccionamiento del concepto, reafirma la idea de la

${ }^{131}$ NERY JUNIOR, N., Revista de Direito Privado, Revista dos Tribunais, Brasil no 179 , p. 100. 
"perturbación de las prestaciones" a causa de - una de las varias hipótesis el rompimiento de la base del negocio (concepto que actualmente está normatizado en el artículo 313 del BGB, Código Civil Alemán), pasando a ser lícita la pretensión del contratante, aunque sea de forma judicial, que tenga como objetivo, la búsqueda de la anterior equivalencia de las prestaciones (dejados de lado, por supuesto, los riesgos normales del contrato) y el restablecimiento de la propia base contractual originaria.

Además, como ya se mencionó y expresó abundantemente en acápite anterior, la idea de "perturbación de las prestaciones", en aquello que interesa de forma más próxima al presente trabajo, actualmente galvanizada a través del citado supra art. 313 del Código Alemán ${ }^{132}$, fue examinada pormenorizadamente por ANTÔNIO MENEZES CORDEIRO, jurista portugués de eximio prestigio, profesor catedrático de la Facultad de Derecho de Lisboa, que razonando sobre el

${ }^{132}$ Este artículo, de forma incisiva, como vista antes, establece los siguiente: Alteración de la base del negocio: 1 . Si con posterioridad a la celebración del contrato se han modificado de modo substancial las circunstancias que han devenido la base del mismo $\mathrm{y}$, de haber previsto esta modificación, las partes no hubieran celebrado el contrato o lo hubieran celebrado con otro contenido, puede exigirse la adaptación del contrato en la medida en que no pueda exigirse a una parte el mantenimiento del acuerdo no modificado, teniendo en cuenta todas las circunstancias del caso concreto, especialmente la distribución legal contractual del riesgo. 2.- Se equipara a una modificación de las circunstancias el hecho que presupuestos esenciales, que han devenido la base del contrato resultan ser falsos. 3.- Si no es posible o no es exigible a una parte una adaptación del contrato, la parte perjudicada puede resolverlo. Para relaciones obligatorias continuadas, en lugar del derecho de rescisión rige el derecho de denuncia." 
tema, aduce que "la expresión 'Derecho de la perturbación de las prestaciones' es una traducción literal de Recht der Leistungsstorungen. Quedarían incluidas las hipótesis de incumplimiento definitivo, de mora y de cumplimiento defectuoso; no obstante, no podemos verter directamente el término para el vernáculo 'incumplimiento en sentido amplio', ya que la denominada perturbación puede abarcar también, además de la imposibilidad, la "culpa in contrahendo", la alteración de las circunstancias y otros institutos. En la actual fase de divulgación, la 'perturbación de las prestaciones' parece adecuada para expresar, con fidelidad, las realidades jurídico-científicas subyacentes".

Concluyendo su opinión, el ilustre jurista portugués afirma que "la 'perturbación de las prestaciones' constituye una fórmula doctrinaria conocida por los especialistas en obligaciones y que se remonta a la clásica monografía de STOLL. Posteriormente, fue adoptada por la literatura de la especialidad como espacio conveniente para abarcar diversas eventualidades que impliquen falta (en todo o en parte) de cumplimiento. En el período anterior a la reforma, podríamos apuntar al 'Leistungsstorungen': un sentido estricto, que comprende la imposibilidad, la mora y la violación positiva del contrato - un sentido amplio, que incluye, además de los tres institutos mencionados, la 'culpa in contrahendo', la alteración de las circunstancias y los contratos con efecto protector de terceros."

\footnotetext{
${ }^{133}$ MENEZES CORDEIRO, A., “Da modernização do Direito Civil”, Vol. I (Aspectos Generales), Almedina, 2004, pp. 100-101.
} 
Esta teoría se distingue de la teoría de BERNARD WINDSCHEID porque, en última instancia, representa parte de una declaración aislada, y la de PAUL OERTMANN (perfeccionada notablemente por LARENZ) se refiere no a una declaración aislada, sino al propio negocio como un todo, el cual, configurado de acuerdo con la realidad sentida por los contratantes, en el momento de la celebración del negocio, no permite una ulterior alteración de esa misma realidad proyectada, en perjuicio de uno de los contratantes.

En suma, la Teoría de la Base del Negocio Jurídico es la representación mental de una de las partes en el contrato aceptada por la otra, o la representación común de ambas en lo que concierne al surgimiento de circunstancias que condicionan la voluntad negocial. Faltando tal base, como fue dicho, puede el contrato ser revisado o ser pasible de resolución.

Esta teoría de la base negocial ("Geschäftsgrundlage”), dígase "a latere”, tras la Segunda Guerra Mundial (1939-1945), fue ampliamente utilizada en Alemania, y es considerada, entre las demás, como la menos imperfecta, sirviendo de eficaz inspiración a los legisladores modernos, especialmente a aquellos de los países occidentales (incluyendo a Italia, con la regla del art. 1467 de su actual Código Civil, Portugal "ex vi" de la regla del art. 1467 del Código Civil Lusitano y Brasil, con su nuevo Código Civil de 2002, que normatizó el tema en su art. 478), seguidores de la familia del Derecho Romano, que acogieron tal entendimiento en normas concretas, en sus respectivos sistemas jurídicos positivos. 
Además, algunos juristas llegan a afirmar que la teoría de la base objetiva del negocio sería una evolución de la teoría de la imprevisión, máxime, teniendo en cuenta la inestimable contribución de la doctrina alemana sobre tan intrincado tema. Los sistemas jurídicos más avanzados del tercer milenio, a causa de una creciente demanda de los consumidores por justicia, ya están a la búsqueda del establecimiento de una correcta modulación para las situaciones jurídicas posibles que versen, sea total o parcialmente, sobre la falta de cumplimiento del contrato, especialmente con relación a la alteración de las circunstancias.

En la actualidad, la regla correcta para establecer un patrón seguro para la necesaria superación de las cuestiones siempre tormentosas - provenientes de la alteración de las circunstancias, deriva claramente del citado art. 313 del BGB alemán, a posteriori de la reforma de los años 2001/2002, que incorporó, sabiamente, nuevas tecnologías jurídicas al sistema, y representa, de esta forma, un seguro avance en la búsqueda de un standard definitivo en relación a las soluciones de la problemática - fáctica y jurídica - derivada de la susodicha alteración de las circunstancias. 


\subsection{Puntos comunes parciales}

Estas son las principales teorías que trataron, con profundidad del asunto, y todas ellas, con mayor o menor intensidad, buscaron justificar, cada una a su manera, la posibilidad de revisión de los negocios jurídicos, siempre que sea comprobada la existencia de hecho sobreviniente al contrato extremamente oneroso para uno de los contratantes, rompiendo con aquella equivalencia material que siempre debe estar presente en los contratos de ejecución continuada o de tracto sucesivo, siempre teniendo como base y fondo la buena fe de los contratantes y los Principios Generales del Derecho, especialmente la equidad.

En otras palabras, estas teorías abordadas, con sus características y modulaciones particulares en uno u otro sentido, para más o para menos, traducen la idea fuerza de que la alteración de las circunstancias representa una excepción a la regla general del deber dogmático del integral cumplimiento del acuerdo. Representan, por lo tanto, rayos de una misma rueda, algo como una instrumental jurídico más o menos uniforme, que pone a disposición una garantía mínima frente a la posibilidad de quiebra de lo pactado, base de la cláusula "pacta sunt servanda".

Esta ideología (cumplimiento integral del contrato bajo cualquier circunstancia), en definitiva, está nítidamente 
vinculada al pensamiento medio que rescata las concepciones rígidas extraídas del antiguo Derecho Romano, principalmente por los glosadores de la Edad Media. Ello repercute con alto y gran impacto en los fundamentos contractualistas posteriores, que permearon la Edad Moderna, principalmente en el período de la sistematización académico-científica de las obligaciones, cuyo elemento principal (verdadero divisor de aguas), fue el Código de Napoleón.

Es decir, esta superada ideología contractual parte del principio de que el contrato, (por sus lejanas raíces históricas provenientes del Derecho Romano, adaptadas a las ulteriores ideologías que pregonaban la absoluta libertad individual), debe siempre ser rigurosamente cumplido. Se buscaba, de esta forma, una conducta ideal, a ser practicada por los contratantes. El raciocinio, sin embargo, debe pasar por otro lado, en un sentido diametralmente opuesto: no existe riesgo cero en contrato alguno. Cualquier operador del derecho, de cualquier país, que se adentre en las lides forenses, esgrimiendo materia contractual, bien sabe de eso.

Por ello mismo, las partes tienen el deber ineludible, derivado de las reglas ordinarias de la buena fe, probidad y equidad (ya en la contratación originaria), de establecer mecanismos, en el propio documento, de calibración efectiva del instrumento, para el caso que ulteriormente sobrevenga una alteración de las circunstancias, incluso para permitir un mejor gerenciamiento /gestión del acuerdo suscripto. 
En eventual ausencia de los antedichos mecanismos (normalmente por olvido de los constructores del contrato o, hasta por la deficiente redacción de las cláusulas pertinentes), la parte aventajada tendrá el deber de aceptar, a la postre, la calibración del instrumento de marras (adecuación equitativa).

Ello podrá ser realizado por determinación judicial, luego de la provocación jurisdiccional, vía los medios legales, por parte del contratante en desventaja. Y resultará calibrado el acuerdo a la luz de la siempre presente e ineludible función social del contrato, además de los postulados probidad, equidad y buena fe citados. Ésta última, la buena fe, es en rigor el principal punto en común de las tres teorías abordadas.

Desde este punto de vista, la necesaria calibración del contrato, debe representar la efectiva adaptación del mismo y sus contornos a las lecciones fácticas de los acontecimientos posteriores, que minaron, en mayor o menor dosis, la propia economía del acuerdo (calibración equitativa del contenido económico del contrato). Esta tarea, en rigor, debe ser ejecutada por los constructores de los instumentos, que, normalmente personifican los laboriosos operadores del derecho, específicamente los abogados.

Por lo tanto, en este específico mosaico, relativo a la necesaria reelaboración y nueva lectura del sistema contractual en los conflictivos tiempos actuales - donde la sociedad 
capitalista o neoliberal propone a los operadores del derecho un diálogo particularmente tenso y muchas veces arisco a la racionalidad jurídica - la ardua tarea de los operadores del derecho pasa por los puntos detallados a seguir. Debe recusar, enérgicamente, los cuestionables criterios de eficiencia y de maximización de la riqueza, fruto de ciertos dogmas corporativos. Los fundamentos para la búsqueda de soluciones jurídicas, especialmente en aquellos contratos que albergan alteraciones imprevisibles, deben conciliar utilidad con justicia y satisfacción económica a través de un intercambio equilibrado. Debe teneres presente que el contrato es un vehículo para la satisfacción de las necesidades humanas, y como tal debe regirse por los principios antedichos.

En realidad, para finalizar este apasionante tópico, sin olvidar las construcciones doctrinarias de los grandes juristas que profundizaron sagaz y meticulosamente sobre el tema, es de destacar el punto neurálgico del mismo, consonante con la provechosa manifestación del jurista brasileño OROZIMBO NONATO, ex Ministro del Supremo Tribunal Federal de Brasil, en la década del cuarenta, y es que "el principio básico de la teoría de la imprevisión, como conquista definitiva del derecho moderno, puede ser aplicado en ciertos casos como fundamento en una de las más generosas fuentes del derecho que son los propios Principios Generales del Derecho, en especial aquellos derivados de la buena fe. La ocurrencia de cierta aleatoriedad en los negocios comerciales a término no elimina la posibilidad de aplicación de la teoría de la imprevisión." 134

${ }^{134}$ NONATO, O., "Curso de obrigações: Generalidades - Espécies”, Forense, Río de Janeiro, 1960, p. 390. 


\section{CRITERIOS OBJETIVOS PARA LA APLICACIÓN DE LA TEORÍA} DE LA IMPREVISIÓN (LA CUESTION DE LA EXCESIVA ONEROSIDAD, FRUSTRACIÓN DE LA FINALIDAD DEL CONTRATO Y DESAPARECIMIENTO DE LA BASE DEL NEGOCIO)

Se verificó, en el capítulo anterior, que las partes, al contratar, vislumbran siempre una equivalencia de las prestaciones asumidas, que reflejen, en definitiva, la necesaria equivalencia material de los bienes de vida que representan el objeto de cualquier contrato.

La eventual y ulterior ausencia del equilibrio planeado en el momento de la celebración y asunción del pacto firmado, traducido en la relación obligacional que surge del contrato, desvirtúa, por cierto, el objeto deseado por los sujetos del propio contrato, justificando, comprobados ciertos requisitos, la búsqueda judicial para deshacer el contrato originariamente firmado, sin imputación de culpa, o su necesaria calibración, caso sea posible la adecuación del mismo contrato a aquellas condiciones y situaciones existentes al tiempo de su nacimiento y perfeccionamiento jurídico. 
En este nivel, para permitir que, surgiendo el problema concreto, en el ámbito contractual, existan indicadores precisos para autorizar la necesaria revisión contractual o dar por deshecho el vínculo, se hace necesario el elenco de algunos requisitos primarios, requisitos éstos que, cuando constatados de forma acumulativa, permiten la invocación de la mencionada doctrina.

Antes que nada, como requisito primero y fundamental, el contrato, pasible de ser encuadrado en la teoría de la imprevisión, debe tener carácter de contrato de ejecución diferida o continuada, o de tracto sucesivo, o sea, aquellos contratos en que el cumplimiento de las prestaciones, asumidas por los contratantes, es sucesivo y regular. ${ }^{135}$

Este requisito, en rigor, forma parte de la propia esencia y filosofía de la teoría de la imprevisión, visto que, en los contratos de ejecución inmediata o instantánea (con la observación bien

135 A este respecto ver distinguida doctrina de FRANCESCO MESSINEO: “...V) La resolución del contrato con prestaciones recíprocas, por excesiva, onerosidad sobreviniente de la prestación (la llamada cláusula sobreentendida rebus sic stantibus). Presupuestos. - Además de las hipótesis hasta aquí analizadas, obra la resolución del contrato también en las hipótesis de excesiva onerosidad sobreviniente. Ella ha sido prevista ante todo, respecto de los contratos con prestaciones recíprocas (véase retro, Cap. VIII, n. 2) que al mismo tiempo sean de ejecución continuada o periódica, o bien todavía de ejecución diferida (art. 1467, inciso 1) (MESSINEO, F., "Doctrina General del Contrato”, T. II - Resolución del Contrato, Ediciones Jurídicas Europa-América, Buenos Aires. 
fundamentada del maestro lusitano CARVALHO FERNANDES, infra transcripta), no tendría sentido considerar hechos imprevisibles, que pudiesen, eventualmente, alterar el original equilibrio contractual. Si la ejecución del contrato tiene carácter instantáneo, la posible y ulterior aplicación de la cláusula "rebus sic stantibus" queda naturalmente perjudicada.

Viene al caso, en el particular, en refuerzo, la explicación e interpretación autorizada de LUIS DIEZPICAZO, que argumenta, con maestría, al disertar sobre los presupuestos de la aplicación de la teoría de la imprevisión, que, en primer lugar, para autorizarse su válida invocación en caso concreto, "la relación obligatoria contemplada ha de ser una obligación de tracto sucesivo, según la terminología de la doctrina tradicional; es decir, lo que nosotros hemos llamado una relación obligatoria duradera. La regla se aplica también en materia de relaciones obligatorias de ejecución instantánea, cuando su cumplimiento ha sido diferido para un momento futuro." $" 136$

En el mismo sentido preconizado la doctrina de CARVALHO FERNANDES, supra citado, sustenta, con gran pertinencia, que "por lo demás, esta es una materia que hace mucho puede considerarse firme y asentada, desde la doctrina clásica con la cláusula 'rebus sic stantibus', como, más tarde, la teoría de la imprevisión,

136 DIEZ-PICAZO, L., “Fundamentos Del Derecho Civil Patrimonial”, 1ª edición, Tecnos, Madrid, pp. 873/874. 
vinculaban en regla el instituto de los contratos de ejecución continuada, periódica o diferida. De lo que se deduce que no se hace necesario que del acuerdo resulten prestaciones que se prolonguen en el tiempo, sea continuada o periódicamente; la obligación puede consumirse en una sola prestación, de ejecución instantánea, siempre que no tenga que ser realizada en el momento de la celebración del acto, sino que su ejecución sea diferida en el tiempo." 137

Como ejemplo, puede citarse un contrato de provisión de mercaderías y/o insumos, entre contratantes empresarios, donde una de las partes, con el objetivo de adquirir con garantía ciertos insumos y/o mercaderías, contrata con la otra la compra de los mismos, estabilizando, en el plazo de duración del contrato, las condiciones pactadas originariamente, principalmente en lo que atañe a la fijación del precio.

Se trata, en realidad, de un contrato que alberga una serie de compras y ventas resguardadas legalmente durante cierto tiempo, garantizando al contratante proveedor/vendedor un mínimo de demanda y, al contratante comprador, la garantía de adquisición de los insumos o mercaderías, con precio y condiciones anteriormente convenidas. En términos negociales, este tipo de contrato permite, a los

137 CARVALHO FERNANDES, “A teoria da imprevisão no Direito Português”, Quid Juris, Lisboa, 2001, p. 276, 
contratantes, en conclusión, un planeamiento empresarial estratégico de largo plazo más eficaz.

Por lo tanto, en esta modalidad de contrato, habrá una necesidad de implemento, sucesivo y regular, en la constancia de lo pactado, de prestaciones y contraprestaciones de ambas partes, o sea, el contratante comprador deberá pagar el precio fijado, como obligación principal y el contratante vendedor deberá entregar los insumos/mercaderías adquiridas también en el plazo del contrato, observándose las condiciones convenidas.

Esta situación, evidentemente, difiere de un mismo contrato de compra y venta con entrega de mercadería en el acto de la adquisición y pago del precio al contado. Esto porque, obviamente, en este contrato el perfeccionamiento del mismo se da de forma inmediata e instantánea, con la entrega de la "res" y pago del precio en el mismo momento. Luego, en este preciso ejemplo, es evidente que no existirán ulteriores eventuales pendencias $\mathrm{y}$, consecuentemente, ulteriores y posibles situaciones imprevisibles, en términos futuros, a ser concretamente tuteladas.

De la misma forma, debe apartarse y dejarse de lado, por notoria impertinencia jurídica, del ámbito de aplicación de la teoría de la imprevisión, los llamados contratos aleatorios (de riesgo), porque, en este caso, como surge claramente, el riesgo correspondiente 
(alea) es de su propia naturaleza, y, por regla, uno sólo de los contratantes asume deberes y obligaciones contractuales.

Así, la incidencia de la teoría de la imprevisión, en determinado contrato, debe presuponer, por lo tanto, que su ejecución se dará durante cierto tiempo, proyectado hacia el futuro, aunque cercano. En otras palabras, el remedio jurídico, contra la excesiva onerosidad sobreviniente, solamente encuentra razón de ser en la distancia que media entre la efectiva estipulación del contrato y el momento de su ejecución.

Además del requisito de la existencia de un contrato de ejecución diferida o de tracto sucesivo, debe verificarse, igualmente, si, en el lapso temporal de su ejecución, sobrevino una situación de absoluta imprevisibilidad, totalmente inexistente al tiempo de la ultimación del propio negocio, causadora de un gran e insoportable perjuicio económico-financiero para uno de los contratantes, situación esta que muestra, a final de cuentas, la destrucción de la base negocial originaria.

En otras palabras, sería la alteración radical de la base del negocio y de las condiciones económicas objetivas, en el momento de la ejecución, en situación diametralmente opuesta, en situación de confrontación, con el ambiente concreto existente en el instante de la formación y celebración del contrato, todo ello haciendo patente la frustración de la finalidad del contrato. 
En realidad, la destrucción de la base del negocio (con la frustración del fin del contrato), posee como marco concreto, y que no puede ser dejado de lado, el momento en que la continuidad del acuerdo, en relación a una de las partes, impone un sacrificio en demasía e insoportable. La correcta evaluación y medida del llamado límite de sacrificio, denominada “Opfergrenze" en la doctrina alemana, para cada caso concreto, autoriza, cuando sea efectivamente demostrada, la utilización del 'gatillo' deflagrador de la invocación de la Teoría de la Imprevisión.

Examinando este apasionante tema, NELSON NERY JUNIOR y ROSA MARIA DE ANDRADE NERY sostienen que la "cuestión siempre presente es saber si, a pesar de las modificaciones económicas sobrevenidas en el curso, o antes, de la ejecución del contrato, es aún posible cumplir la voluntad de las partes. Hay un límite para exigir el sacrificio de las partes"138 $\mathrm{y}^{139}$. Sin duda

138 "Código civil comentado e legislação extravagante", $3^{\mathrm{a}}$ edición, Revista dos Tribunais, p. 405.

139 La idea del "límite del sacrificio", calcada en la "Teoría del esfuerzo", fue bien enfrentada por CARLOS GHERSI, al realizar sus disquisiciones sobre la reparación de daños contractuales, producidos por las leyes de emergencia económica argentinas, en la grave crisis cambial de comienzos de siglo, al sostener que "la idea es que hay un límite de sacrificio más allá del cual no puede imponerse un mayor esfuerzo al obligado. No se le puede exigir al deudor una actividad extraordinaria o irrazonable fuera de sus posibilidades que excede el grado de inmensidad del esfuerzo normal". (GHERSI, C., 
alguna, debe observarse, siempre, "la regla moral según la cual no es lícito a uno de los contratantes aprovecharse de las circunstancias imprevistas e imprevisibles subsecuentes a la conclusión del contrato, para onerar al otro contratante más allá del límite en que habría consentido en obligarse", como expresa en nítida y precisa lección el insigne FRANCISCO CAMPOS. ${ }^{140}$.

LUIS DIEZ-PICAZO, con su célebre autoridad doctrinaria nos dice que "la desaparición de la base del negocio ha de producirse como consecuencia de una alteración de las circunstancias que deba considerarse como extraordinaria, en relación con las existentes en el momento de la celebración del contrato y que, además, resultara en aquel momento radicalmente imprevista e imprevisible. No han de tenerse en cuenta, por lo tanto, las transformaciones de las circunstancias que fueron previsibles o que se encontraban en la esfera de influencia de la parte perjudicada."

Para finalizar, aduce el excelso jurista que "por la misma razón tampoco ha de ser tenida en cuenta una transformación de las circunstancias cuando el riesgo haya sido el motivo determinante del negocio, como sucedería en un contrato aleatorio, o

"Reparación de daños contractuales producidos por la emergencia económica”, Nova Tesis, Buenos Aires, 2002, p. 105.)

${ }^{140}$ CAMPOS, F., “Revisão dos contratos: Teoria da Imprevisão” - Direito Civil, p. 8. 
cuando la alteración sobrevenida forme parte del riesgo asumido, por una de las partes de acuerdo con la naturaleza del tipo de negocio." 141

En realidad, no podría ser otro el entendimiento, ya que el contrato, representa un valioso instrumento de satisfacción económica, asentado en la equivalencia de las prestaciones, oriundas de la base del negocio entablado. Destruida esa base, el contrato debe ser revisado, conforme aclara, en su gran contribución, JORGE A. MAYO, al afirmar que "podemos concluir, en esta perspectiva, que la economía del contrato asume el rol de instrumento idóneo para determinar su suerte frente a circunstancias tales como la excesiva onerosidad, lo que aunado a otras pautas, entre ellas la cláusula general de la buena fe - en este aspecto, en cuanto límite al ejercicio de la pretensión por el acreedor, y en tanto regla que controla la actuación del deudor en la etapa de ejecución - serán las armas con las que el juzgador deberá resolver equitativamente la compleja problemática que se presenta." ${ }^{, 142}$

A partir de ahí que sea correcto inferir que la cláusula "rebus sic stantibus" está siempre implícita en cualquier contrato de ejecución continuada o diferida, aunque no se encuentre

${ }^{141}$ DIEZ-PICAZO, L., Fundamentos del Derecho Civil Patrimonial”, $1^{\text {a }}$ edición, Tecnos, Madrid, p. 874.

${ }^{142}$ MAYO, J.A., "Estudios de derecho civil - parte general", La Ley, Buenos Aires, 2005, p. 21. 
expresa en el contrato, como es el caso, por ejemplo, de la cláusula de evicción."143

En este punto, la idea central es la siguiente: cuando ocurran circunstancias que vengan a destruir totalmente la relación de equivalencia o la proporción entre las prestaciones (base económica del contrato), con la consecuente frustración de la finalidad del contrato, tal como fuera querido, originariamente por las partes, el contratante en desventaja económica estaría apto, autorizado, a invocar, en su favor, la aplicación de la teoría de la imprevisión; puesto que, si las partes hubiesen podido prever la alteración futura de las circunstancias informadoras del nacimiento del contrato, éste, con seguridad, no hubiera sido suscripto.

143 Conforme esmerada doctrina, la cláusula de evicción está siempre implícita en cualquier contrato oneroso, aunque no esté explícita en el pacto, pudiendo las partes, sin embargo, restringirla o suprimirla. En esta línea, por ejemplo, el Código Civil de la Nación Argentina, (art. 2097: "La responsabilidad (...) la evicción tiene lugar, aunque en los derechos no hubiere convención alguna sobre ella.”), el Código Civil Español (art. 1475: "El vendedor responderá de la evicción aunque nada se haya expresado en el contrato”), el Código Civil Boliviano (art. 628, II: “Aun cuando se pacte la exclusión de responsabilidad el vendedor está siempre sujeto a la responsabilidad por un hecho propio. Es nulo todo pacto contrario") y el Código Civil de Brasil (art. 449: "no obstante la cláusula que excluya la garantía de evicción, si esta se da, tiene derecho el evicto a recibir el precio que pagó por la cosa sujeto de evicción, si no supo del riesgo de la misma, o si de él informado, no lo asumió”). 
Dicho de otra forma, en consonancia con la interpretación de CARVALHO FERNANDES, "la alteración se considera anormal, o anómala, cuando produce un sobresalto, un accidente, en el curso ordinario o serie natural de los acontecimientos. Hay pues, un desvío del fluir o evolución normal de las circunstancias que se verificaron en el momento de la celebración del negocio." 144

Sobre el particular, constátese lo expuesto, siempre provechoso y fructífero, por parte del jurista brasileño CARVALHO SANTOS, para quien la aplicación, en los casos concretos, de la teoría de la imprevisión es como "una condición implícita, en virtud de la cual se pretende que, en cierta categoría de contrato se deba considerar subordinado a la continuación de aquel estado de hecho existente, al tiempo de su formación, de tal suerte que, modificado por motivos sobrevinientes e imprevistos, el objetivo anterior, la fuerza obligatoria del contrato no debe ser mantenida, justificándose la intervención judicial, para reverlo o rescindirlo."

Con este entendimiento, destáquese, tampoco discrepa el doctrinario brasileño MIGUEL DE MARIA SERPA

144 CARVALHO FERNANDES, “A teoria da imprevisão no Direito Civil Português”, Quid Juris?, Lisboa, 2001, p. 291.

145 CARVALHO SANTOS, "Repertório enciclopédico do direito brasileiro", V.XI, Borsoi, São Paulo, p.6. 
LOPES, que sustenta que "la imprevisión consiste, así, en desequilibrio de las prestaciones sucesivas o diferidas, en consecuencia de acontecimientos ulteriores a la formación del contrato, independientemente de la voluntad de las partes, de tal forma extraordinarios y anormales que se tornaba imposible preverlos anticipada y razonablemente. Son acontecimientos sobrevinientes que alteran profundamente la economía del contrato, de tal forma perturbando su equilibrio, como inicialmente estaba fijado, que se hace patente que las partes jamás contratarían si hubiesen podido antes prever dichos hechos. Si, en tales circunstancias, el contrato fuese mantenido, redundaría en un enriquecimiento anormal, en beneficio del acreedor, determinando un empobrecimiento de la misma naturaleza, en relación al deudor. Consecuentemente, la imprevisión tiende a alterar o excluir la fuerza obligatoria de los contratos."

Como ejemplo concreto, para una mejor ilustración, puede mencionarse aquella relación contractual, de tracto sucesivo, alterada, en términos económicos, por el sobrevenir de una inflación galopante, capaz de reducir, sustancialmente, con perjuicio insoportable, el valor de la prestación a ser efectivamente implementada.

Véase un contrato de compra y venta de equipamiento industrial, con pago de seña (arras), por parte del contratante comprador y obligación de fabricación y entrega, de ese mismo equipamiento, después del curso de cierto tiempo, por el contratante

146 SERPA LOPES, M de M., "Curso de direito civil" $3^{\mathrm{a}}$ edición, Vol. III, Río de Janeiro, 1991. 
vendedor, ocasión en que éste deberá recibir la parte final del precio, anteriormente acordado.

Supóngase, en este mismo ejemplo, que, en el curso de la producción del equipamiento encomendado, sobreviene, en el país de los contratantes originarios, una situación imprevisible de anormalidad e inestabilidad económica, haciendo con que el precio de las mercaderías e insumos en general sufra, de un día para el otro, un substancial aumento, en progresión geométrica, todo sujetado a una creciente inflación, por causa del caos económico entonces instalado.

¿Cómo quedará, en este caso concreto, el contratante que se obligó a fabricar y entregar el equipamiento encomendado después del paso de cierto lapso temporal, con un precio ya convenido, y que, al momento de la contratación, no vislumbró, como tampoco la otra parte, la posibilidad de alteración de las condiciones económicas?

Resulta evidente, en este caso, que la imprevisibilidad de la alteración de la política macroeconómica puede, legítimamente, servir de fundamento para justificar la invocación de la teoría de la imprevisión, por lo tanto, "prima facie", sería penoso y cruel que el contratante proveedor se viese compelido a soportar un perjuicio no vislumbrado (pago del precio de los insumos para la fabricación de los equipamientos, al precio del día, etc.), razonablemente, en ocasión de la contratación. En otras palabras, el ejemplo alberga una situación ulterior, 
totalmente desfavorable a uno de los contratantes, por la destrucción, en definitiva, de la propia base originaria del negocio.

En este sentido, la situación, supra apuntada, por estar dentro de un contexto de imprevisibilidad, cuando efectivamente probada e informadora de un franco desequilibrio contractual, actúa, sin controversia, como verdadera excluyente de la obligatoriedad de cumplimiento contractual por la parte virtualmente afectada, que, evidentemente, no se exime de probar la circunstancia imprevisible en juicio, como verdadero prerrequisito para buscarse, judicialmente, deshacer el vínculo contractual sin imputación de culpa o la posible búsqueda de la adecuación del contrato a los mismos niveles del pacto originario.

En este sentido, la situación, supra apuntada, por estar dentro de un contexto de imprevisibilidad, cuando efectivamente probada e informadora de un franco desequilibrio contractual, actúa, sin controversia, como verdadera excluyente de la obligatoriedad de cumplimiento contractual por la parte virtualmente afectada, que, evidentemente, no se exime de probar la circunstancia imprevisible en juicio, como verdadero prerrequisito para buscarse, judicialmente, deshacer el vínculo contractual sin imputación de culpa o la posible búsqueda de la adecuación del contrato a los mismos niveles del pacto originario. 
Es menester, sin embargo, en este tópico, abriendo un pequeño, pero significativo paréntesis, hacer una pequeña digresión acerca de la efectiva extensión y aplicabilidad de la idea de imprevisibilidad, en los límites de la cláusula "rebus sic stantibus", que no se debe confundir con las situaciones derivadas del caso fortuito o de fuerza mayor, si bien que, eventualmente, puedan tales conceptos contener puntos eventuales de convergencia.

Inicialmente, aunque exista, aún actualmente, una cierta confusión doctrinaria en lo que concierne a la correcta diferenciación de lo que sea caso fortuito o fuerza mayor, seguimos aquí la clásica doctrina romanista orientada por las enseñanzas de los notables y célebres jurisconsultos GAIO y ULPIANO. Sobre el concepto y extensión de la fuerza mayor, GAIO afirma que "vis maior est cui humana intirmitas resistire non postest". En una traducción libre, el concepto gravita alrededor de la idea de que la fuerza mayor es un hecho imprevisible, derivado, básicamente de la acción humana (por ejemplo, guerras, revoluciones, etc.).

Por su parte, en relación al caso fortuito, DOMICIO ULPIANO lo definió de la siguiente forma, con su singular erudicción: "fortuitus casus est, qui nullo humano consilio praevideri potest". También en una traducción libre, el concepto orbita en torno de la idea fundamental de que el caso fortuito es aquél que no puede ser previsto por la acción humana, en la medida en que derivaría de un acontecimiento de orden estrictamente natural ("verbi gratia" terremotos, erupciones volcánicas, rayos, etc.). 
En la misma línea de razonamiento, las fundamentales enseñanzas del emérito profesor portugués CUNHA GONÇALVES, en su festejada obra Tratado de Direito Civil, em comentário do Código Civil Português, propugna que "la opinión más exacta es la que considera como caso fortuito el hecho imprevisto e irresistible, y fuerza mayor al acontecimiento que podía ser previsto, pero no dominado o evitado, por lo menos dentro de las posibilidades y con las fuerzas del deudor. Esta distinción, sin embargo, no tiene valor práctico alguno, visto que ambos casos producen efectos idénticos en relación a la responsabilidad." 147

Por otro lado, la situación fáctica que trae aparejada la aplicación de la cláusula "rebus sic stantibus", al contrario del caso fortuito o fuerza mayor (aunque, subráyese como importante, en algunos casos concretos, pueda haber puntos fácticos de convergencia), reside en la simple alteración del estado de hecho existente en la ocasión en que el contrato tuvo inicio, con la consecuente (requisito acumulativo) quiebra de la equivalencia de las prestaciones y onerosidad excesiva para uno de los contratantes, de lo que surge cristalinamente la quiebra de la base del contrato y un perjuicio económico insoportable.

A partir de allí podemos extraer las siguientes conclusiones y consecuencias: en el caso fortuito o fuerza

${ }^{147}$ CUNHA GONÇALVES, "Tratado de Direito Civil, em comentário do Código Civil Português”, Vol. IV, Coimbra Editora, Coimbra, 1932 , p. 526. 
mayor, cuando comprobados, existe, como resultado directo de tal cuadro fáctico, la total imposibilidad de cumplimiento de la prestación por parte del contratante respectivo, actuando como verdadera y legítima causa excluyente del cumplimiento de la obligación asumida.

Ahora, en la cláusula "rebus sic stantibus", el punto nodal reside en la verificación del estado de hecho en el período post-contrato, con el nacimiento de una situación de onerosidad excesiva para uno de los contratantes, galvanizada a un perjuicio absurdo para ese mismo contratante, de lo que surge en forma patente la quiebra de la base del negocio y la frustración de la finalidad del contrato.

Por lo tanto, no se trata de imposibilidad plena del cumplimiento de la obligación (en rigor, en ciertos casos, el contratante hasta podría, en tesis, cumplir la obligación asumida, aunque excesivamente onerosa), sino, de la posibilidad de invocación de una eficaz tutela jurídica, teniendo como telón de fondo una singular situación fáctica, derivada de un contrato regular, con reflejos absolutamente negativos en la esfera económica de uno de los contratantes, de forma de restablecer, en última instancia, la propia base negocial originaria del contrato.

En la misma línea, la autorizada posición del ponderado y laureado civilista brasileño SILVIO RODRIGUES, en el particular, sustenta que "no es menester que la prestación se torne imposible para que el deudor se libere del vínculo contractual. Basta que, a través de hechos extraordinarios e imprevisibles, 
ella se convierta en excesivamente onerosa para una de las partes. Ocurriendo esto, puede el perjudicado pedir la rescisión del negocio." 148

Siguiendo en la misma dirección argumental, tenemos la posición serena y distinguida de INOCÊNCIO GALVÃO TELLES, también ilustre catedrático de la Facultad de Derecho de Lisboa, que afirma que, en el contexto de la imposibilidad, dificultad de la prestación y alteración de las circunstancias, “(...) de la imposibilidad propiamente dicha debe distinguirse la dificultad de la prestación. La primera supone que la prestación es irrealizable, física o legalmente; la segunda, que la prestación es realizable, pero sólo a través de sacrificios o esfuerzos excepcionales."

Concluyendo su agudo y pertinaz razonamiento, el mencionado jurista portugués, al avanzar en el concepto de la dificultad de la prestación (“difficultas praestandi”), brindando a su privilegiado lector claros y pedagógicos ejemplos, agrega que "la prestación se presenta aquí excesivamente onerosa o costosa, tomados estos adjetivos en una acepción no necesariamente económica. No es imposible, pero es particularmente difícil realizarla, en el sentido de que para ello será necesario hacer sacrificios extraordinarios o desmesurados, sean éstos de orden financiero, personal o moral. Por ejemplo, en razón del acentuado encarecimiento de los materiales o salarios, el empresario sólo puede construir la obra arruinándose o sujetándose a un sacrificio que va más allá

${ }^{148}$ RODRIGUES, S., “Direito Civil”, Vol. III, Saraiva, São Paulo, p 21. 
del riesgo normal de un contrato. Alguien promete vender a otro una joya, de valor relativamente bajo; antes de celebrar la compraventa, la joya cae accidentalmente al mar, siendo posible su recuperación pero a costa de trabajos y gastos excesivos. Un actor tiene una indisposición que no le impide participar en el espectáculo; sin embargo, su actuación tendría como consecuencia desmejorar sensiblemente su salud." 149

La invocación y aplicación de la teoría de la imprevisión, por lo tanto, permitirá que el Estado-juez realice la necesaria revisión, o conceda, en el juicio que sea procedente, deshacer el vínculo contractual sin imputación de culpa para ninguna de las partes, con base en la probada alteración de las circunstancias, motivadora de la posible y potencial ruina económica de uno de los contratantes, en el corto plazo, contrariamente a la invocación de fuerza mayor o caso fortuito, que piden prueba robusta e incontestable de la imposibilidad absoluta de implementación de la prestación por parte del contratante respectivo.

Más adelante, en un capítulo autónomo y destacado, serán enfrentadas, con más detalle, las cuestiones procesales referentes a las acciones abstractamente puestas a disposición del contratante en situación de inferioridad. Esto porque, obviamente, la invocación, en juicio, de eventuales factores imprevisibles, excluyentes de la obligatoriedad de cumplimiento de las obligaciones asumidas

149 GALVÃO TELLES, I., "Direito das obrigações”, $7^{\mathrm{a}}$ edición, Coimbra Editora, Coimbra, 1997, p. 325. 
originariamente en el contrato, debe ser promovida de forma cautelosa y con un análisis procesal minucioso acerca del correcto cabimiento de las pretensiones a ser deducidas. Caberá al juez, por lo tanto, en cada caso concreto, elegir dentro del sistema las normas de interpretación más afinadas al caso "sub judice". 150

Además, como tercer requisito, el contratante en situación de desventaja debe comprobar, de forma indudable, la imposibilidad de cumplimiento de la prestación, sin que sufra un absurdo e insoportable perjuicio económico, antes de que la prestación respectiva, debida al otro contratante, se haga exigible.

Se trata de un requerimiento que no puede ser dejado de lado y que representa la esencia de la teoría, ahora potenciada con las demarcaciones de la teoría de la base del negocio jurídico. En otras palabras, se recomienda al contratante en desventaja que, a la menor señal de imposibilidad de cumplimiento de la prestación, por causa, se reitera, de un factor imprevisible, informante de una excesiva onerosidad, sea el otro contratante inmediatamente notificado, por

150 Según LOUIS JOSSERAND, discurriendo sobre la cuestión de las normas de interpretación, "Estas directivas, que llevan el sello del buen sentido y de la equidad, son simples recomendaciones sin carácter obligatorio para el juez, prácticamente al menos, ya que su inobservancia no da ciertamente lugar a casación; pertenece al juez del fondo del asunto interpretar soberanamente los contratos; si se equivoca, viola el contrato, no la ley; únicamente la ley ha sido constituida en elemento a ser protegido por la Corte de Casación; solo la violación de la ley puede servir de base a un recurso aquí." (JOSSERAND, L., "Derecho Civil”, Tomo II, Vol. I, traducción de Santiago Cunchillos y Manterola, Buenos Aires, 1950, p.157.) 
cualquier medio idóneo y legal, como forma de impedir que su conducta, de no cumplimiento de la obligación, sea acreditada a un estado moroso, que, ciertamente, tendría la capacidad de debilitar la posición de la parte víctima el hecho imprevisible.

Los eruditos jurisconsultos romanos ya aseguraban, con mucha propiedad, que el derecho no socorre a los que duermen (“dormientibus non succurrit jus"). Empleándose esa vieja máxima jurídica, en un contexto contractual donde se discute la posible aplicación de la teoría de la imprevisión, resistiéndose el contratante debilitado a tomar una decisión tendiente a dar noticia de la nueva situación fáctica, ahora de por sí extremamente onerosa, puede ser confundido con un deudor moroso, en caso de que el plazo de cumplimiento de la prestación se haya agotado.

Lo expresado supra deviene de que, como es sabidamente conocido, la mora puede ser considerada como retardación culposa en el cumplimiento de la obligación contractual asumida en el pacto, cuando la prestación aún puede serle útil al otro contratante.

En esta ocasión, si el contratante en desventaja no informa el hecho sobreviniente, imprevisible y extremamente oneroso, dejando de cumplir la obligación sin cualquier excepción válida y, consecuentemente, incurriendo en mora, no estará más en condiciones de invocar la imprevisibilidad como factor de exclusión legítima en el 
cumplimiento de la obligación anteriormente asumida, porque, estando en estado de morosidad configurado, esta retardación permitirá que la otra parte pueda ejercer, válidamente, en última instancia, el derecho potestativo de resolución del contrato, con la correspondiente y posible imputación de culpa. ${ }^{151}$

Los doctrinarios lusitanos ANDRADE PIRES DE LIMA y MATOS ANTUNES VARELA también comparten dicha opinión, en el sentido de que el contratante moroso, y potencialmente perjudicado, no goza del derecho de resolución o modificación del contrato, por la alteración de las circunstancias. Lo hacen en comentarios y anotaciones a los arts. 437 y 438 del actual Código Civil Portugués, que disciplina jurídicamente el asunto: "es una consecuencia de los principios en que se asienta el derecho conferido por el artículo anterior (437). La alteración de las circunstancias supone, en realidad, una modificación verificada entre el momento del contrato y el momento en que las obligaciones emergentes del mismo deben ser cumplidas (conforme Prof. Vaz Serra). Por lo demás, quien se coloca en mora no puede aspirar a cualquier protección resultante de hechos sobrevinientes."

\footnotetext{
${ }^{151}$ Precisamente, sobre este asunto, PONTES DE MIRANDA afirma que "el cambio de las circunstancias, para que haya que atender a sus consecuencias, debe haber sido, a más tardar, en el momento en que tendría que ser cumplido el contrato, o mientras él está siendo cumplido, sin mora. La mora debitoris y la mora creditoris han de ser posteriores al cambio. Si aquélla o ésta son anteriores, la responsabilidad es del deudor o del acreedor en mora, según los principios generales.”, PONTES DE MIRANDA, “Tratado de Direito Privado”, Parte Especial, Tomo XXV, Borsoi, p. 255.

${ }^{152}$ PIRES DE LIMA y ANTUNES VARELA, J de M. “Código Civil anotado”, Vol I, Coimbra Editora, Coimbra, 1967, p. 291.
} 
ALMEIDA COSTA, con pertinente comentario a los artículos supra citados, ínsitos, como fue expuesto, en el Código Civil Portugués de la actualidad, especialmente refiriéndose a la norma del art. 438, y perfilando el mismo entendimiento expuesto, nos ilustra con lo siguiente: “(...) fácilmente se comprende este requisito. Coloca a tal respecto el art. 438 del Código Civil que 'la parte lesada no goza del derecho de resolución o modificación del contrato, si estaba en mora en el momento en que la alteración de las circunstancias se verificó'. Se trata de una disciplina conforme a la estructura del instituto y las propias consecuencias, en relación a hechos sobrevinientes, de la mora culposa (conforme el art. 807) - la única que el art. 438 abarca. Así, por el contrario, si el cumplimiento fue retardado por la imposibilidad temporaria de la prestación, inimputable al deudor, puede éste incoar su derecho de resolución o modificación del contrato, en los términos generales."

Finalizando su pertinaz entendimiento, ALMEIDA COSTA sustenta, que "la ley se refiere al momento en que se produce la alteración de las circunstancias. Por lo tanto, si esta alteración antecede a la mora, 'no es el simple hecho de que el deudor haya incurrido en mora lo que le impide pedir la resolución o modificación del contrato' (conforme Pires de Lima y Antunes Varela). Parece ser una solución indiscutible. Como también es dable admitir que, habiendo prorrogación del plazo por acuerdo de partes, deberá atenderse a la finalidad que tuvieron en vista, a efectos de la aplicación de la doctrina de la posible 
resolución o modificación del contrato las alteraciones posteriores a esa prorrogación." 153

El último requisito se refiere, como no podría ser de otra manera, a la prueba incontestable de la verificación de la excesiva onerosidad en contra de uno de los contratantes, que comunica el nacimiento de una grave desproporción en la necesaria equivalencia de las prestaciones. Esta desproporción, contemplando una extrema ventaja para el otro contratante, debe comunicar y justificar la necesidad de revisión del propio contrato, de manera que rescate la base originaria del negocio derivado de la voluntad original de las partes.

Dicho de otro modo, debe quedar probada la alteración radical de las condiciones y circunstancias de cuño económico, objetivamente existentes en el momento de la constitución del vínculo contractual, en cotejo con el momento de la ejecución del propio contrato, de forma que no eche por tierra el mantenimiento, en el acuerdo, de la necesaria equidad, que siempre debe estar presente en los contratos de ejecución continuada o diferida.

Esta prueba (de las alteraciones radicales de las condiciones y circunstancias, de cuño económico del contrato), debe ser aportada y realizada, obviamente, por la parte que buscará, judicialmente, la revisión del pacto, puesto que, en principio,

153 ALMEIDA COSTA, "Direito das obrigações”, 4ª edición, Coimbra Editora, Coimbra, 1984, pp. 229/230. 
como regla general, la carga de la prueba, en juicio, compete a quien alega, a excepción, claro, de las demandas que envuelvan contratos derivados de una relación de consumo.

Esto es así, porque, en dicho preciso caso, como se sabe, con el surgimiento del llamado derecho de las relaciones de consumo o del consumidor (que traduce, en realidad, el surgimiento de una nueva rama del derecho privado, quebrando aquella dicotomía anterior, entonces existente, entre el derecho civil y el derecho comercial, para agregar una nueva rama al derecho privado, o sea, el propio derecho del consumidor), los legisladores de los países occidentales, en su mayoría, apoyaron una ideología de plena protección contractual al consumidor, dentro de un microsistema específico, apoyado, sobre todo, en la plena buena fe y protección de la parte más débil (el propio consumidor). A partir de allí tenemos, entre otros beneficios explícitos, aquél que establece, en favor de ésta (contratante consumidor), la inversión de la carga de la prueba. 


\section{EFECTOS JURÍDICOS DE LA REVISIÓN JUDICIAL O DE LA RESOLUCIÓN DEL CONTRATO}

\subsection{De la posibilidad de utilización de acción cautelar por el contratante en desventaja}

Habiendo uno de los contratantes constatado la existencia de excesiva onerosidad, en las circunstancias anteriormente señaladas en otro capítulo, sin posibilidad de cumplimiento del contrato sin que ocurra un sacrificio inmenso, con la quiebra de la base del negocio originario, se debe buscar el correspondiente ajuste o su modulación por la vía judicial, invocando el interesado el otorgamiento de la competente y respectiva prestación jurisdiccional.

Además, no podría ser de otra forma, teniendo en cuenta que el Estado, en definitiva, tiene el deber de tutelar, "lato sensu" los intereses de sus ciudadanos, cuando por cualquier razón, hay un ataque serio e intenso a la esfera jurídica de los mismos, especialmente cuando ocurre, de forma concreta (para no perder el foco del presente estudio), una situación contractual de absoluta anormalidad, notificadora de la alteración significativa de las circunstancias.

En este espectro, en el ambiente de la alteración de las circunstancias y onerosidad contractual excesiva, debe buscarse la legítima protección estatal en caso de efectiva y palpable perturbación de la paridad contractual (para usar la oportuna expresión de 
la doctrina alemana), en senda, también, de las enseñanzas de REINHARD SINGER, profesor catedrático de la Humboldt-Universitat de Berlín, que expresa lo siguiente: "también aquí fue nuevamente CLAUS-WILHELM CANARIS quien indicó el camino: de los derechos fundamentales derivan deberes de protección para el Estado. En principio, el Estado tiene que realmente abstenerse de intervenir en el tráfico jurídico-privado, pues es justamente la idea fundamental de la libertad contractual dejar en las propias manos de los sujetos de derecho privado la configuración de sus relaciones jurídicas. Ahora bien, cuando la libertad contractual no funciona, a causa de la autodeterminación haber sido transformada o convertida en "heterodeterminación", el Estado y, llegado el caso, el sistema de la Jurisdicción, precisan intervenir en aras de aquélla." 154

Evidentemente que la opción judicial presupone, conforme las reglas primarias y ordinarias de experiencia común, que las alternativas de negociaciones extrajudiciales de calibración y adecuación del contrato resulten infructuosas (sin ningún éxito). O sea, debe siempre, como premisa mayor, buscarse una solución extrajudicial para la solución de la controversia. La judicialización del problema solamente debe acaecer cuando las alternativas de composición amigable no hayan prosperado. En la opinión de JOSÉ DE OLIVEIRA ASCENSÃO, emérito y erudito profesor de la Facultad de Derecho de Lisboa, "sólo cuando las partes no se entiendan sobre el sentido de la solución legal y se

\footnotetext{
${ }^{154}$ SINGER, R., "Direitos fundamentais e Direito Privado. Uma perspectiva de Direito Comparado”, Organizadores Antônio Pinto Monteiro y otros, Almedina, pp. 332/333.
} 
decidan a traer el caso al foro es que el juez interviene efectivamente y da la respectiva solución." 155

Así, optando el contratante virtualmente perjudicado por el inicio, en proceso, de la demanda respectiva, debe inicialmente, formular pretensión con el objetivo de la revisión judicial del pacto, teniendo como principales fundamentos la buena fe y la búsqueda del mantenimiento de la base inicial objetiva del negocio originario. ${ }^{156}$

Esta alternativa debe ser la primera a ser contemplada por el contratante en desventaja, hasta porque, en términos económicos, el contrato es siempre el vehículo jurídico-económico que

${ }^{155}$ DE OLIVEIRA ASCENSÃO, J., “Questões controvertidas no novo Código Civil Alteração das circunstâncias e justiça contratual no novo Código Civil', Método, São Paulo, p. 188.

${ }^{156}$ Véase a este respecto, la elaborada doctrina de JORGE MOSSET ITURRASPE, que afirma que "El juez cumple, en todo lo relacionado con este remedio, un rol muy importante. Decide, de acuerdo con su buen sentido y logos de lo razonable, acerca de si el o los hechos invocados reúnen los extremos de extraordinariedad e imprevisibilidad, para lo cual no hay ni puede haber parámetros fijos. Decide, con iguales herramientas, acerca de si la incidencia de tales hechos configura o no la onerosidad excesiva que está en la base del remedio. Finalmente, y en la cuestión que ahora analizamos, es el juez, como director del proceso de revisión, quien ha de lograr la "razonable recomposición mediante una valoración discrecional, a actuar en vista de la entidad total del contrato y en el sentido de que el sacrificio de una de las prestaciones deje de ser intolerable" 
pretende, en última instancia, garantizar a las partes el éxito de sus intereses y objetivos económicos inmediatos y mediatos.

Con esta extensión conceptual, debe valorarse la plena movilidad del sistema, sin poder obviar ciertas cláusulas integradoras, como, por ejemplo, la de la buena fe. ${ }^{157}$ Ello porque no puede concebirse ni aceptarse, hasta en homenaje a los dictados de la buena fe objetiva (que deben ser observados por los contratantes involucrados, hasta los que están en desventaja, como fuera afirmado en otro tópico del presente estudio), como posible mecanismo estratégico basado en la mala fe y contrariando la equidad, que el contratante perjudicado pueda valerse de la alegada onerosidad excesiva para desvincularse, pronta y totalmente, del contrato.

Esa idea tiene que ser vigorosamente rechazada y repudiada, merced a los ya citados principios de la buena fe, por representar una estrategia de opresión en disfavor del otro contratante

\footnotetext{
${ }^{157}$ Según CLAUUS WILHEM CANARIS, “El 'sistema móvil’ está, legislativamente, entre la formación de previsiones normativas rígidas, por un lado, y la cláusula general, por otro. Él, permite confrontar de modo particularmente feliz, la polaridad entre los "más altos valores del Derecho", en especial la 'tendencia generalizadora' de la justicia y la 'individualizadora', y constituye, de esta forma, un enriquecimiento valioso del instrumental legislativo. No debe, sin embargo, ser utilizado de forma exclusiva, sino representar una posibilidad legislativa entre otras vinculadas entre sí.” (CANARIS, C.W., "Pensamento Sistemático e Conceito de Sistema na Ciência do Direito", $4^{\text {a }}$ edición, Fundação Calociste Gulbenkian.)
} 
que no pude ser aceptada. No obstante, existen casos en que, concretamente, esa posibilidad de calibración es imposible, siendo, como consecuencia, recomendada su resolución, o sea, la disolución total del vínculo por determinación judicial.

De ahí que devenga, por lo tanto, una importante conclusión, a nivel de procedimiento y procesal: el contratante perjudicado deberá formular pretensión, en la respectiva petición inicial, basada en fundamentos en orden sucesivo, o sea, el magistrado, conductor de la causa, deberá, en primer lugar, evaluar si es posible la revisión parcial del contrato, de forma que rescate, en última instancia, la equivalencia de las prestaciones y la propia base originaria del negocio, alejando, de esa forma, la onerosidad excesiva invocada, cuando la pretensión fue puesta en juicio. $^{158}$

Según la esmerada y notable doctrina latinoamericana, con base en las enseñanzas de NELSON NERY JUNIOR y ROSA MARIA DE ANDRADE NERY, “(...) la imprevisión posibilita no sólo la resolución del contrato, sino también su revisión, caso eso sea del interés de las partes. Habiendo disenso entre ellas sobre la revisión, aún

158 Art. 427 del Código Civil Portugués: “(...) si las circunstancias en que las partes fundaron la decisión de contratar hubieran sufrido una alteración anormal, tiene la parte perjudicada derecho a la resolución del contrato, o a la modificación del mismo según juicios de equidad, desde que la exigencia de las obligaciones por ella asumidas afecten gravemente los principios de la buena fe, y no esté cubierta por los propios riesgos del contrato." 
así es posible que sea hecha judicialmente, mediante sentencia determinante del juez. El fundamento para la revisión judicial del contrato es la incidencia concomitante de las cláusulas generales, de la función social del contrato, de la buena fe objetiva y de la base objetiva del negocio." 159

No siendo posible la revisión parcial del contrato, mediante decisión debidamente fundamentada, solamente en esta hipótesis sería permitido al juez entrar a conocer la pretensión posterior, formulada en la misma demanda, de resolución total (disolución total del vínculo) del contrato.

En el Derecho Procesal Civil brasileño, como ejemplo, existe expresa disposición y autorización en este sentido, en el respectivo Código de Proceso Civil de 1973, en cuyo art. 289 se afirma verbis: 'Es lícito formular más de un pedido en orden sucesivo, a fin de que el juez merite sobre lo posterior, no pudiendo acoger lo anterior'. ${ }^{160}$ En

159 "Código Civil Comentado e legislação extravagante", Revista dos Tribunais, $3^{\text {a }}$ edición, p. 405.

160 Conforme las enseñanzas de VICENTE GRECO FILHO, el pedido en orden sucesivo se caracteriza por su índole subsidiaria. "El pedido es subsidiario cuando el autor formula un pedido principal, solicitando que el juez merite uno posterior en caso de no poder acoger el primero. Así, por ejemplo, en los casos de obligación de hacer o no hacer, el pedido principal es el de la práctica del acto o abstención de hecho, no obstante, si no se obtiene la conducta deseada, entonces se solicita o bien la práctica de ella por un tercero, si la obligación es fungible, o bien la conversión en daños y 
otras palabras, el contratante perjudicado deberá dirigir la acción, en el proceso competente, de revisión de contrato, con pedido en orden sucesivo para su resolución.

Se busca, con eso, en el específico ambiente jurídico de los contratos, valorizar el mantenimiento del acuerdo siempre que eso sea, concretamente posible, en la medida en que la invocación de la teoría de la imprevisión, como ya fue enfatizado, no puede ser utilizada como permisión incuestionable para atender, hasta de forma promiscua, la potencial resolución del contrato.

La idea central, se repite, que siempre deriva de la posibilidad de revisión, es el rescate, por la vía judicial, del equilibrio económico-financiero del acuerdo y de la propia base objetiva del negocio, con el mantenimiento del contrato observándose las condiciones originariamente previstas.

Esta posición, es la que mejor se combina y armoniza con otro principio fundamental existente en el ámbito de los contratos, que es, el principio de la conservación de los negocios jurídicos, siempre implícito en las demandas que puedan traer aparejada, como solución extrema, la resolución total del propio pacto.

perjuicios, en caso de que la obligación sea infungible. El Código califica ese pedido como sucesivo". (GRECO FILHO, V., "Direito Processual Civil Brasileiro", Vol. II, $16^{a}$ edición, Saraiva, São Paulo, 2003, p. 106). 
En la autorizada interpretación de PIETRO PERLINGIERI, citando a BOSELLI, y comentando el art. 1467 del actual Código Civil Italiano, "sul rimedio alternativo alla risoluzione, rappresentato dalla riduzione del contratto ad euità, la dottrina si è espressa prevalentemente nel senso di ritenere l'atto dell'offerta come um autonomo potere di modifica unilaterale del contratto, attribuito dalla legge al contraente onerato al fine di consentire la conservazione del negozio." 161

Por ese motivo, por ejemplo, en el derecho positivo brasileño (art. 479 del Código Civil de 2002), se antepone, como primera alternativa sustancial posible, objetivando la búsqueda de una solución proporcional, la posibilidad de que el contratante demandado modifique, equitativamente, las condiciones del contrato, haciendo cesar la propalada onerosidad excesiva en el caso concreto, después de su citación a la causa.

En su misma senda el derecho positivo portugués, al establecer, en el artículo 437, 2º del actual Código Civil lusitano, que "requerida la resolución, la parte contraria puede oponerse al pedido, declarando aceptar la modificación del contrato en los términos del número anterior" (in artículo citado).

${ }^{161}$ PERLINGIERI, P., “Codice civile annotato com la dottrina e la giurisprudenza”, Libro IV, UTET, p. 623. 
Igualmente, en el mismo nivel, el ya citado art. 1467 del Código Civil italiano, verdadero monumento jurídico de la humanidad, solamente comparable al Código de Napoleón, que preconiza, sin rodeos, que "la parte contro la quale è domandata la risoluzione può evitarla offrendo di modificare equamente le condizioni del contratto" (in dispositivo citado).

Dicho de otra forma, en caso de que el contratante demandado no esté de acuerdo, después de haber tomado conocimiento de la demanda, por medio de citación regular, en modificar, de forma equitativa, las condiciones del contrato, y siendo posible el mantenimiento de ese mismo contrato, el juez de la causa podrá, merced al pedido formulado por el contratante en desventaja, corregir las distorsiones apuntadas y modificar la cláusula contractual motivadora del nacimiento de la ausencia de equidad, haciéndose la necesaria revisión judicial del contrato.

En la moderna doctrina procesal civil alemana, el juez, en tal universo, podrá modificar el pacto firmado mediante dictado de sentencia de contenido determinativo ("festsetzendes Urteil”), siempre amparándose en las cláusulas generales que integran los más avanzados sistemas jurídicos en materia de contratos, con sustento en las cláusulas generales de buena fe objetiva y función social del contrato.

Puesto de otra forma, con esta modalidad de sentencia, el juez no substituye, sino que integra el propio 
negocio jurídico. Conforme la autoridad doctrinal de NELSON NERY JUNIOR y ROSA MARIA DE ANDRADE NERY, en tal hipótesis, "esa sentencia, que en realidad tiene naturaleza determinativa, esto es, integrativa del negocio jurídico, es tarea que es dada por el sistema al juez, por lo tanto no hay otro modo de que él concrete las cláusulas generales sino redactando la nueva cláusula contractual. La función jurisdiccional aquí se asemeja a la de la jurisdicción voluntaria, sólo que litigiosa. Al respecto cabe afirmar que el juez integra, participa en el negocio jurídico privado, pero no actúa en sustitución de la voluntad de las partes contratantes." 162

Como consecuencia, no ocurrirá la disolución del vínculo contractual, puesto que, obviamente, no existirá la extinción correspondiente. El contrato subsistirá, con las modulaciones necesarias, manteniéndose eficaz y generando los efectos jurídicos correspondientes, con las nuevas reglas impuestas por el juez. El fundamento para este actuar, como medio de salvar el acuerdo, evidentemente, está basado y atrincherado en la propia función social del contrato y prestigio ilimitado de la buena fe objetiva, que debe ser rigurosamente observada por los contratantes, hasta porque, como ya fuera señalado, se presenta como uno de los pilares del sistema.

Además, merced a la citada función social de todo y cualquier contrato, se exalta, sobremanera, en el ámbito de ${ }^{162}$ NELSON NERY JUNIOR y ROSA MARIA DE ANDRADE NERY, “Código civil comentado e legislação extravagante”, $3^{\text {a }}$ edición, Revista dos Tribunais, p. 383. 
la comunidad y/o sociedad, el mantenimiento del negocio jurídico entablado por las partes, cuya conservación, por cierto, representa, en última instancia, el enaltecimiento de una ideología basada en el equilibrio y la paz social.

Sin embargo, como ya fue manifestado, no siendo tal salida posible, la resolución del contrato deberá ser la otra alternativa recomendada, en lugar de la acción incoada, en la medida en que, en esta precisa hipótesis, no será más razonable el mantenimiento, invocada la imprevisibilidad como factor de onerosidad excesiva, del vínculo contractual existente, merced a la natural posibilidad de creciente opresión económica del contratante perjudicado. ${ }^{163}$

Recordando nuevamente, la evolución histórica de la teoría de la imprevisión, y su creciente incorporación a los sistemas jurídicos que tomaron forma principalmente a partir del siglo $\mathrm{XX}$,

${ }^{163}$ Merece registro, por relevante, y para que no haya dudas al respecto, que cuando se habla de deshacer el vínculo por onerosidad excesiva, por la utilización de acción jurisdiccional competente, no es para decretar la nulidad del contrato. Es, solamente, a fin de hacer retornar a las partes (rigurosamente) al estado anterior a la contratación, extrayéndose de allí las consecuencias jurídicas pertinentes y necesarias. Por su parte, la nulidad absoluta del contrato, cuando ocurre, es una situación totalmente diferente, y normalmente deriva de la no observancia, por los contratantes originarios, de ciertos reglamentos coagentes, existentes en el ordenamiento jurídico positivo, que consideran como nula cierta disposición existente en el instrumento de marras. Por ejemplo, en el Derecho Brasileño, existe norma expresa que dispone que es nulo el contrato de compraventa cuando la fijación del precio queda, exclusivamente, al arbitrio de unos de los contratantes (conforme art. 489 del Código Civil Brasileño). 
con la creciente flexibilización del absolutismo contractual ya referido, consagra el ideario de que la seguridad de los contratos reposa y reside, fundamentalmente, en la buena fe de las partes, como regla inamovible de conducta (tanto en la celebración como en la ejecución del pacto respectivo), siempre enfatizándose que la buena fe objetiva, por su propia naturaleza, es considerada cláusula general, al mismo tiempo en que se consustancia en fuente natural de derechos y obligaciones para las partes involucradas, que no pueden dejarlas de lado ni renunciar por cualquier motivo a ellas.

Con la resolución operada, en las hipótesis en que dicha solución es recomendada (labor, evidentemente, a ser realizada por el magistrado, caso a caso), se extingue la relación contractual anteriormente instaurada, siempre recordando que, de acuerdo con la sedimentada doctrina, la resolución es una de las modalidades de extinción del pacto, decantada de causas sobrevinientes a su formación, por el no cumplimiento de las obligaciones asumidas por uno de los contratantes. ${ }^{164}$

\footnotetext{
${ }^{164}$ Para el doctrinario ULHOA COELHO, la resolución resulta del no cumplimiento de las obligaciones asumidas por una de las partes, sean derivadas de acción u omisión a ella imputables (resolución voluntaria o culposa), sea en función de factores externos a la actuación del contratante que imposibilitan la ejecución del contrato como, por ejemplo, el caso fortuito, la fuerza mayor o la insolvencia. - (ULHOA COELHO, F., “Manual de Direito Comercial”, 15ª edición, Saraiva, São Paulo, 2004, p. 420)
} 
Nótese que, en esta precisa hipótesis (de resolución por onerosidad excesiva, que siempre es ulterior a la celebración del contrato, como se vio exhaustivamente), la no ejecución de la obligación (prestación) asumida por el contratante en desventaja no deriva, evidentemente, de hecho imputable al propio deudor, puesto que esta no ejecución (de la obligación asumida) posee la marca característica de ser involuntaria, al contrario de la no ejecución voluntaria, que obliga al deudor a indemnizar los daños y perjuicios correspondientes, en favor de la otra parte. $^{165}$

De ahí la relevante consecuencia que se extrae de esta modalidad de resolución (resolución con base en causa involuntaria): el contratante deudor no podrá ser condenado a indemnizar eventuales daños y perjuicios, ya que se encuentra ausente el elemento culpa, la imposibilidad de cumplimiento obligacional, por onerosidad excesiva, como fue visto, señala la posibilidad de extinción del contrato, por motivo ajeno a la voluntad de las partes; sin culpa, por lo tanto, sin

\footnotetext{
${ }^{165}$ La doctrina más tradicional, de los sistemas jurídicos de los países occidentales, comulga con el entendimiento de que, en principio, la no ejecución del contrato confiere al contratante inocente, además de la posibilidad de deshacer el vínculo por causa de la conducta culposa del otro contratante, la indemnización por los daños y perjuicios correspondientes - aquello que perdió y razonablemente dejó de ganar. Cesare Vivante, por ejemplo, afirma que, "en los contratos bilaterales el Código Civil subentiende siempre la cláusula resolutoria, por la cual el contratante, que cumplió su obligación, tiene el derecho de exigir, de aquel que no cumplió, o el cumplimiento del contrato o su resolución, con indemnización por daños y perjuicios." ("VIVANTE, C., "Instituições de Direito Comercial”, traducción de Ricardo Rodrigues Gama, LZN, 2003).
} 
cualquier tipo de indemnización a ser abonada por el firmante del convenio que fue perjudicado.

Cuanto mucho - y apenas porque, con la resolución, que opera efectos retroactivos sobre la situación acaecida, las partes retornan a la situación jurídica anterior al contrato que hubo de ser disuelto - la otra parte tendrá solamente el derecho de pleitear la restitución de lo que hubiera entregado en el cumplimiento de sus obligaciones contractuales adquiridas hasta el momento del acaecimiento de las circunstancias que son obstáculo y óbice a la continuación normal y ordinaria del pacto.

Esto porque, en otras palabras, deshecho el vínculo contractual por causa del reconocimiento, por parte del juez de la causa, de la existencia de onerosidad excesiva, deben las partes volver al estado anterior al contrato firmado, merced al carácter igualmente restaurador de lo dictaminado por el magistrado en relación al señalado ligamen vinculador de las partes.

Como bien observa JOSSERAND, citando a RIPET y NARSON ${ }^{166}$, "del mismo modo en que las prerrogativas conferidas por ley, los derechos derivados del contrato tienen su finalidad específica, su función propia. Cumple, entonces, que en ejecución del ajuste, las partes tengan en consideración su espíritu y los fines de los

166 JOSSERAND, L., “De l'esprit des droits”, nº 119. 
derechos de los que sean titulares. El desvío de ellos de sus finalidades será anormal, abusivo e irá contra la función del contrato".

En rigor, no podría ser de otra forma, ya que con la desarticulación del vínculo que unía a las partes originarias a su conducta contractual, incumbe siempre al juez de la causar buscar cohibir la inmoderación, para que el derecho, en última instancia, se preste a la realización de la efectiva justicia y no permita la superposición de intereses que no guarden armonía con la buena convivencia social y buena fe, que siempre debe nortear, como un intocable faro, el espíritu de los contratantes.

Además de lo expresado, es dable resaltar, aún conexo al tema de la natural y automática restauración de la situación previa, que en el examen judicial del caso concreto, la determinación de retorno de las partes al estado anterior independe de pedido expreso del otro contratante, puesto que, siendo imposible la ejecución del convenio, por la onerosidad excesiva, ya mencionada, la consecuencia ulterior debe ser exactamente el inmediato restablecimiento de la situación fáctica y económica pretérita.

En este orden de ideas, en situaciones de la referida naturaleza, jamás habrá, a nuestro juicio, eventual decisión "extra petita", a causa de la eventual ausencia de pedido expreso de la otra parte, en relación a la posible devolución de las prestaciones anteriormente abonadas en el curso de la ejecución anterior del convenio. 


\subsection{De la posibilidad de utilización de acción cautelar por el contratante en desventaja}

Estando el contratante en desventaja apto para incoar acción de revisión contractual (o similar) o, alternativamente, de desvinculación del acuerdo, en el caso de no ser posible la calibración del mismo, de forma de rescatar la anterior equivalencia de las prestaciones, le es facultado, en el especial ámbito de las acciones cautelares, buscar, con carácter preparatorio o incidental, tutela cautelar. La misma, si es conferida, lo desobligará a cumplir la prestación reputada onerosa, hasta que se dicte la correspondiente sentencia sobre el mérito, o sea, el veredicto relacionado con la pretensión inicial deducida (como expresado, acción de revisión o desvinculación contractual).

Es oportuno recordar que, en términos procesales, los sistemas jurídicos occidentales, dan como concreto derecho de garantía al interesado, la posibilidad de entablar acción cautelar, de carácter preparatorio o incidental, donde el mérito a ser juzgado es bien limitado, o sea, la acción gravita alrededor de la propia pretensión de seguridad o a la posibilidad de anuencia de protección jurisdiccional anticipada, de naturaleza parcial o total. ${ }^{167}$

167 Ya se sostuvo que "el legislador hubo de desarrollar y dar forma a un tipo de procedimiento teniendo en mira prevenir y resguardar las causas de conocimiento y de ejecución, asegurando, de esta forma, la obtención de un resultado provechoso al final del proceso considerado de fondo. Así, en paralelo, conforme definición de las más 
Esta última alternativa representa, efectivamente, la propia concesión de la prestación jurisdiccional, presentes ciertos requisitos, que autorizan al magistrado, al conocer y juzgar el caso concreto, bajo determinadas circunstancias, anticipar los efectos de la decisión de mérito. Ésta, no debe olvidarse, no se confunde, en absoluto, con el mérito de la acción cautelar propiamente dicha, que orbita, como ya fue resaltado oportunamente, en la simple pretensión de seguridad jurídica. La situación de marras, muchas veces, permite al juez, aún haciendo lugar inicialmente a la acción cautelar, venir, en el juzgamiento específico de la cuestión de fondo, declarar el requerimiento improcedente, si fue probada,

usuales, el procedimiento cautelar tiene por finalidad inmediata garantizar la eficacia práctica de la providencia definitiva, salvaguardando, de este modo, según la docencia del insigne Liebman, un resultado útil, cuando llegue la ocasión de la definitiva entrega de la tutela jurisdiccional. En este sentido, y coherente con tal línea de raciocinio, a fines de ilustración, nunca es en vano traer a colación la posición del profesor Eliezer Rosa, que propugna que "las medidas cautelares son pertinentes para proteger el interés de las partes frente al perjuicio de la demora natural de los procesos judiciales". Por consiguiente, sintetizando el tema, es evidente que el proceso de tipo cautelar tiene por objetivo, salvaguardar el interés de derecho material de las partes involucradas, en vistas de un peligro prominente. Deriva de ello, que para su ejercicio, siempre que la hipótesis lo admita, podrá el litigante interesado, valerse de sus efectos inmediatos, que aliados al poder general de cautela conferido al magistrado (art. 798 del Código de Proceso Civil Brasileño), tendrán la capacidad de protegerlo del peligro inminente que ronda hasta la providencia definitiva (tutela jurisdiccional) a ser determinada en el proceso considerado como principal. En resumen, se trata del derecho a la pretensión de seguridad" (FERNANDES ALMEIDA, R., "Revista Justitia", Ministerio Público de São Paulo, Vol. 148, 1989, p.16) 
ulteriormente, la ausencia de necesidad de la pretensión de seguridad instada.

En el derecho brasileño, por ejemplo, en relación a la anticipación de la tutela jurisdiccional (art. 273 del Código de Proceso Civil vigente, caput), se exige, de forma acumulativa, para hacer lugar a la misma, la existencia de prueba inequívoca y verosimilitud de la alegación, sin omitir la existencia de fundado recelo de daño irreparable o de difícil reparación.

En cualquiera de las alternativas mencionadas, sin embargo, se exige como condición necesaria y punto principal de convergencia, la prueba irrefutable del daño irreparable o de difícil o dificultosa reparación. Ello, en la medida en que el sistema no contempla una acción específica, a fin de darle solución del problema (lo que conlleva o conllevaría el menoscabo y potencial daño que será causado por la exigencia, del acreedor, del cumplimiento de la prestación onerosa convenida). Este elemento, parte de la doctrina jurídica de vanguardia em diversos países concordo en darle la denominación de tutela inhibitoria de daño. $^{168}$

\footnotetext{
${ }^{168}$ El derecho procesal civil más conservador, como regla general, no contempla una verdadera y específica acción de conocimiento de carácter inhibitorio, centrado que está en el tradicional modelo trinario de las sentencias, estando esta cuestión, en la actualidad, siendo objeto de incipientes estudios (especialmente en la doctrina italiana) para buscarse la construcción de una teoría capaz de establecer nuevos parámetros científicos principalmente en el ámbito procesal, de tutela preventiva. (1) La construcción, por lo tanto, de un nuevo modelo procesal, que contemple la utilización,
} 
por el poder jurisdiccional, de una tutela inhibitoria, capaz de prevenir el daño, derivado de una relación contractual o extracontractual, debe contemplar la búsqueda constante de la efectividad del derecho requerido por el interesado, teniendo por objeto final la propia prevención del daño. (2) En la actualidad, no obstante la inexistencia de un modelo estructurado capaz de viabilizar, de forma indudable, la utilización de una acción de conocimiento inhibitoria autónoma, apta para no ser confundida con otras modalidades de tutela (en el ámbito limitado de las acciones cautelares), es posible encontrar en el ordenamiento jurídico positivo acciones con aspecto inhibitorio ("verbi gratia" acciones contra el uso nocivo de la propiedad, acciones de interdicto prohibitorio para la protección de los llamados bienes inmateriales, tales como, marca comercial, derecho de autor, etc.). (3) En este sentido, como delineamientos básicos, se puede establecer, como principales requisitos para la utilización de la tutela inhibitoria, por orden, la prueba de la amenaza de daño a ser potencialmente causado, la prueba de la existencia de un concreto temor fundado, y la prueba, finalmente, de que el potencial daño denunciado debe, necesariamente, advenir de una conducta antijurídica. (4) La pretensión a ser deducida, así, se asienta en la tutela protectora frente a una posible y plausible amenaza, a ser comprobada por el interesado y capaz de generar, por eso mismo, al final del proceso correspondiente, juicio procedente, con determinación para que la parte demandada, potencial causadora del daño que se procura evitar, se abstenga de practicar lo ilícito. (5) Presentes estos aspectos substantivos, de carácter no procesal, podrá el interesado valerse de la tutela inhibitoria, que, sabidamente, es más barata, en la medida que es más eficaz prevenir que, en el futuro, buscar una posible (y muchas veces improbable) indemnización. 


\section{CAPÍtULO V}

1. Derecho Comparado en América Latina: la buena como sustentáculo de la aplicación de la Teoría de la Imprevisión en los sistemas jurídicos del subcontinente

2. Las leyes de emergencia en Argentina, en el período de la grave crisis económica de finales del siglo XX e inicio del siglo XXI

2.1. De la revisión de los contratos por alteración de las circunstancias en larga escala en el sistema jurídico argentino 


\section{DERECHO COMPARADO EN AMÉRICA LATINA: LA BUENA FE COMO SUSTENTO DE LA APLICACIÓN DE LA TEORÍA DE LA IMPREVISIÓN EN LOS SISTEMAS JURÍDICOS DEL SUBCONTINENTE ${ }^{169}$}

Inicialmente, en el Derecho latinoamericano en general, antes de cualquier consideración más profunda sobre el tema de fondo, en el ámbito geográfico citado, se aplica, plenamente, la regla de la buena fe en los contratos de cualquier naturaleza, por herencia e influencia, inmediata o mediata, del Código Civil francés, cuyo art. 1134 dice que las convenciones y pactos "deben ser ejecutados de buena fe", mientras que su art. 1135 dispone que "obligan no sólo a lo que está expresado en ellos, sino a todas las consecuencias que la equidad, el uso o la ley, dan a la obligación según su naturaleza". El mismo texto legal es reproducido con igual tenor por el art. 1135 del Código Civil de la República Dominicana.

Por otro lado, el art. 1954 del llamado Esboço de TEIXEIRA DE FREITAS, brillante y notable jurista brasileño

\footnotetext{
169 Se hace notar, "ad cautelam”, que pudo haber eventuales y recientes alteraciones legislativas en los ordenamientos jurídicos de los países latinoamericanos mencionados en este tópico de forma concomitante o ulterior a la presente investigación. Esta advertencia es de importancia, ya que, histórica y culturalmente, las modificaciones en el sistema legal ocurren con bastante frecuencia y facilidad, muchas veces sin el necesario diálogo previo de maduración entre el poder legislativo y el cuerpo social (sometidos a la jurisdicción / destinatarios de las normas jurídicas de marras) respectivo.
} 
del siglo XIX, para efecto de confección de un Código Civil en el periodo del Brasil Imperial, preveía, en sentido semejante al del Código Civil Francés, bebiendo de la misma fuente, que "los contratos deben ser cumplidos de buena fe", y que "obligan no sólo a lo que expresamente se hubiese convenido, sino a todo lo que, según la naturaleza del contrato, sea de ley, equidad o costumbre". Con igual alcance, el art. 1291 del Código Civil del Uruguay, que también dispone que los contratos "deben ejecutarse de buena fe, y por lo tanto obligan, no sólo a lo que en ellos se expresa, sino a todas las consecuencias que, según su naturaleza, sean conforme a la equidad, el uso o la ley".

También encontramos en el Código Civil de Bolivia (Decreto -ley 12.760), en su art. 581, el texto que consagra la aplicación de la Teoría de la Imprevisión, al autorizar la disolución del vínculo del pacto firmado por excesiva onerosidad. En igual sentido, los arts. 1160 del Código Civil de Venezuela, y el art. 1023, inciso primero, del Código Civil de Costa Rica, establecen que "los contratos deben ejecutarse de buena fe y obligan no solamente a cumplir con lo expresado en ellos, sino también a todas las consecuencias que se derivan de los mismos, según la equidad, el uso o la ley".

Por su parte, el art, 1546 del Código Civil de Chile, repetido por el art. 1603 del Código Civil de Colombia, el art. 1589 del Código Civil del Ecuador, el art. 1417 del Código Civil de El Salvador y el art. 1546 del Código Civil hondureño disponen, de forma igualitaria, que "los contratos deben ejecutarse de buena fe, y por lo tanto obligan no sólo a lo que en ellos se expresa, sino a todas las cosas que 
emanen precisamente de la naturaleza de la obligación, o que por la ley o la costumbre pertenezcan a ella".

Asimismo, el art. 1109 del Código Civil de la República de Panamá también establece, sin lugar a dudas, que los contratos "obligan a los contratantes no sólo al cumplimiento de lo expresamente pactado, sino también a las consecuencias que, según su naturaleza, sean conformes a la buena fe, al uso y a la ley. En la misma línea, el art. 1796 del Código Civil del Distrito Federal mexicano, repite, literalmente, este mismo texto.

Por otro lado, el art. 131, inciso primero, del nuevo Código Civil del Brasil (del año 2002), igualmente prevé que, "los contratantes están obligados a respetar, tanto en la celebración del contrato como en su ejecución, los principios de probidad y buena fe".

Por su parte, el art. 689 del Código Civil paraguayo del año 1987 dispone, en la misma senda, que "en el desarrollo de las negociaciones y en la formación del contrato, deben las partes comportarse de acuerdo con la buena fe". Por otro lado el art. 1362 del Código Civil del Perú de 1984 preconiza que "los contratos deben negociarse, celebrarse y ejecutarse según las reglas de la buena fe y común intención de las partes. Dicho texto coincide, integralmente, con el art. 1519 del Código Civil de Guatemala. 
Finalmente, el art. 1198 del Código Civil Argentino (en su versión de 1871), ya en el siglo XIX, verdadero marco de la codificación científica del Derecho Civil en la América del Sur, establecía que "los contratos obligan no sólo a lo que está formalmente expresado en ellos, sino a todas las consecuencias que puedan considerarse que hubiesen sido virtualmente comprendidas". La reforma legal del año 1968 lo substituyó por otro texto, pero aquél anterior fue recuperado en el proyecto de las reformas del Código Civil de la Nación de 1998 (arts 967 y 1023).

Actualmente, como herencia directa de ese ideario, la posibilidad concreta de revisión de los contratos está contemplada en el artículo 1198, párrafo $1^{\circ}$, del Código Civil de la Nación Argentina, que dispone lo siguiente, "in verbis": "En los contratos bilaterales conmutativos y en los unilaterales onerosos y conmutativos de ejecución diferida o continuada, si la prestación a cargo de una de las partes se tornara excesivamente onerosa, por acontecimientos extraordinarios e imprevisibles, la parte perjudicada podrá demandar la resolución del contrato".

Esa redacción e inserción legal en el derecho positivo argentino derivó de una propuesta del Tercer Congreso de Derecho Civil de Córdoba, realizado en el año 1961, y presentada, en aquel importante evento, por el ilustre jurista y doctrinario argentino JORGE MOSSET ITURRASPE, teniendo como base y sustento la postura de la buena fe que las partes contratantes, en última instancia, deben observar. 
Por ser un instituto relativamente nuevo, en términos de derecho positivo argentino, la norma lo describe con todos sus pormenores, de donde se percibe, la presencia de tres de los requisitos basilares para la aplicación de la Teoría de la Imprevisión, a saber: a) existencia de un contrato de ejecución diferida o continuada; b) existencia de un grave desequilibrio en las prestaciones acordadas y c) acontecimiento sobreviniente que extrapola la ordinaria previsibilidad de las partes, en ocasión de la celebración del contrato. ${ }^{170}$

En el marco conceptual derivado del dogma (o casi dogma) de la autonomía de la voluntad, el Código Civil Chileno (a ejemplo del Código Civil del Uruguay ${ }^{171}$ ) no contempló la teoría

${ }^{170}$ Obsérvese, en esta línea de pensamiento, la interesante sentencia de la justicia argentina, refereida por el catedrático JORGE MOSSET ITURRASPE: "Decisión de equidad, ha dicho la Cám. $1^{\text {a }}$ Civil y Comercial de Bahía Blanca (Provincia de Buenos Aires), que "aunque el contrato no previese plazo para la ejecución de las prestaciones, o éstas no fuesen diferidas, es suficiente que la agravación desproporcionada de la prestación del deudor se hubiere producido, y que esa circunstancia no fuera previsible normalmente en el acto de la celebración, para que sea aplicable el principio del nuevo art. 1198 del Cód. Civ.”, en E. D. 55-140. Cám. Nac. Civ., sala C, 9/5/77, en la causa "Aycor S. A. c/ Parrone, A. y otra", hizo lugar al reajuste en una compraventa de un departamento (J.A. N N0506, del 10/8/77) (MOSSET ITURRASPE, J., “Responsabilidad por daños”, Buenos Aires, 1971.

${ }^{171}$ El sistema legal positivo de Uruguay aunque, como fue visto, disponga de una norma de integración (el art. 1291 de su Código Civil, que reza que "[los contratos] deben ejecutarse de buena fe y por consiguiente obligan, no solo a lo que en ello se expresa, 


\section{Alteración de las Circunstancias y Revisión Contractual}

de la imprevisión. Sin embargo, varios juristas del país cordillerano dedicaron grandes e intensos esfuerzos para la incorporación de la misma a su sistema jurídico, utilizando como argumento central la exégesis del artículo 1546 del respectivo Código Civil, según el cual el contrato debe ser ejecutado de buena fe.

La Universidad Gabriela Mistral, de Santiago de Chile, por ejemplo, en el año 1993, elaboró un proyecto de ley sobre la revisión judicial de los contratos, que fue ampliamente discutido en el seminario organizado sobre revisión judicial de los contratos, con sustento en la buena fe, que integra el contenido del contrato con base en cláusulas que derivan del deber de buena fe. Fueron analizados, en la ocasión, los efectos jurídicos derivados de esas cláusulas y su correcta

sino a todas las consecuencias que según su naturaleza sean conformes a al equidad o al uso o a la ley"), no contempla, objetivamente, la Teoría de la Imprevisión. A este respecto puede verse, por ejemplo, la doctrina de JORGE GAMARRA, "in verbis": "El Tomo XVIII del Tratado de Derecho Civil Uruguayo continuó la doctrina de mis predecesores en la cátedra, Amézaga, Peirano Facio y Sánchez Fontans; allí la cuestión de la procedencia de la teoría de la imprevisión fue planteada fundamentalmente como un problema de derecho positivo y política legislativa. Desde este ángulo solamente cabe una respuesta negativa, porque el art. 1291 incicso 1 establece la inmutabilidad de los contratos sin distinguir si varían o no las circunstancias iniciales, como consecuencia de acontecimientos externos, sean estos extraordinarios o no, previsibles o imprevisibles. En el artículo que corresponde a nuestro 1291 se basa también la Corte de Casación francesa para la cual ninguna consideración de tiempo o equidad permite que los jueces modifiquen los contratos. El derecho francés afirma la intangibilidad del contrato y condena la Teoría de la Imprevisión". ( GAMARRA, J.,"Imprevisión y equivalencia contractual”, "in” Cuadernos del Anuario de Derecho Civil Uruguayo, Fundación Cultura Universitaria, Montevideo, 2006, p.55). 
interpretación, en el sentido de la búsqueda de un resultado que no sea contrario a la buena fe o al sentido común del hombre honesto y probo.

De esta forma, sintetizando el temario, se nota, por la conjugación armoniosa de los dispositivos supra e retro colocados, que la buena fe es la verdadera puerta de entrada, el principal punto de convergencia, para la correcta interpretación jurídica de los contratos y del efectivo alcance deseado por los contratantes, tanto al momento de su celebración como al momento de su ejecución.

Esos principios de buena fe tienen el efectivo atributo de moldear, o buscar moldear, la justicia contractual que siempre debe estar presente en todo y cualquier pacto lícito, autorizando, en los casos concretos, como consecuencial, la aplicación de la cláusula "rebus sic stantibus" y sus respectivas variantes.

Dicho de otro modo, la inclusión de los principios de la buena fe en los ordenamientos jurídicos positivos citados, muestran, de una forma general, que los Códigos Civiles latinoamericanos adoptan tales conceptos como pautas integradoras o interpretativas de las leyes y de los casos concretos, en el ambiente respectivo del derecho de los contratos, con "status" de cláusula general.

En otras palabras, las directrices de los Códigos Civiles latinoamericanos anteriormente relacionados, apuntan hacia la consolidación de directrices sociales efectivas para la 
interpretación de las leyes vigentes, teniendo como objetivo la búsqueda y mantenimiento de la deseada justicia contractual, con base, como cimiento que no puede ser dejado de lado, en la buena fe de los contratantes.

Así, la regla de la buena fe pasa a albergar la importante virtud de calibrar la autonomía de la voluntad, actuando como verdadera fuente homogénea que integra y corrige la voluntad de las partes en relación al efecto vinculante del acuerdo, en determinados casos de flagrante desequilibrio ulterior del pacto, con reflejos en propia determinación de la prestación debida.

De esta forma, merced a la construcción y consolidación de este marco conceptual, es perfectamente previsible la expansión de la admisión de las virtualidades del cambio de las circunstancias en materia contractual a todos los sistemas jurídicos. De ello resulta un magnífico ejemplo de la relevancia de la buena fe, como cláusula general, y de los Principios Generales del Derecho, exaltados por la tarea de los juristas que, después de interpretar reconstructivamente el sistema vigente, señalan y traen las nuevas soluciones y tendencias actuales de la "praxis" negocial.

Como fecundo ejemplo de esa tendencia en el ámbito de América del Sur, más precisamente en el perímetro del MERCOSUR, los actuales y ya citados Códigos Civiles argentino y brasileño, que se circunscribieron, originariamente, al dogma de la autonomía de la voluntad, acabaron por sucumbir a las nuevas ideas de los 
juristas de vanguardia, más afinados con la realidad social y económica de los contratos, que moldearon los respectivos sistemas jurídicos mediante la articulación y calibración de la cláusula "pacta sunt servanda" con el principio "rebus sic stantibus".

Si la justicia contractual requiere, por un lado, el respeto al principio de la cláusula "pacta sunt servanda", requiere, por el otro, de igual manera, que ese mismo principio sea compatibilizado con el mantenimiento de la equivalencia de las prestaciones, para el mantenimiento de la base del negocio, en los casos en que el curso natural y ordinario de las cosas sale do su cauce originario.

Por eso mismo es que, en la doctrina moderna, se atribuye a la efectiva interpretación del contrato un alcance bien más amplio del que la mera exploración del significado de sus cláusulas oscuras o ambiguas, por el reconocimiento de que cualquier contrato, por más dubio, imprevisible o mal redactado que sea, incluye ciertos deberes implícitos de los contratantes, emanados de la regla primaria y siempre presente de la buena fe. 


\section{LAS LEYES DE EMERGENCIA EN ARGENTINA, EN EL PERÍODO DE LA GRAVE CRISIS ECONÓMICA DE FINALES DEL SIGLO XX E INICIO DEL SIGLO XXI}

\subsection{De la revisión de los contratos por alteración de las circunstancias en larga escala en el sistema jurídico argentino}

Como se expresó anteriormente, los actuales modelos normativos más avanzados contemplan, en cada microcosmos de cada respectivo sistema, la posibilidad de revisión contractual por la alteración de las circunstancias. El sistema jurídico argentino de hoy en día no escapa de esta regla, conforme el ya citado art. 1198 de su Código Civil $^{172}$, que autoriza expresamente la adopción de tal criterio de eventual revisión de contratos.

${ }^{172}$ El art. 1198 del Código Civil Argentino ostenta, actualmente, el siguiente enunciado:
"Los contratos deben celebrarse, interpretarse y ejecutarse de buena fe y de acuerdo con lo que verosímilmente las partes entendieron o pudieron entender, obrando con cuidado y previsión. En los contratos bilaterales conmutativos y en los unilaterales onerosos y conmutativos de ejecución diferida o continuada, si la prestación a cargo de una de las partes se tornar excesivamente onerosa, por acontecimientos extraordinarios e imprevisibles, la parte perjudicada podrá demandar la resolución Del contrato. El mismo principio se aplicará a los contratos aleatorios cuando la excesiva onerosidad se produzca por causas extrañas al riesgo propio del contrato. En los contratos de ejecución continuada la resolución no alcanzará a los efectos ya cumplidos. No procederá la resolución, si el perjudicado hubiese obrado con culpa o estuviese en mora. La otra parte podrá impedir la resolución ofreciendo mejorar equitativamente los efectos del contrato". En el mismo sentido, existe en el actual Derecho Griego una disposición semejante en su Código Civil. Este mecanismo jurídico, de calibración de contratos y obligaciones correlativas a los mismos, por onerosidad excesiva, podrá ser extremamente útil en la actual coyuntura de crisis económica que asola al país helénico 
De esta forma, la inserción, por parte del legislador ordinario argentino, de tal mecanismo de control, tiene por fin, en última instancia, colocar a disposición de las partes una herramienta jurídica eficaz para la solución de controversias contractuales actuales. Ello, como ya fue expuesto, surge ordinariamente, con mayor o menor intensidad, de las relaciones humanas que gravitan alrededor de los contratos.

En otras palabras, siempre que el legislador inserta, como criterio normativo de revisión en determinado sistema jurídico, la posibilidad de calibración del contrato por alteración de las circunstancias, lo hace objetivando establecer una directriz mínima que pueda permitir la magistrado, en el caso concreto, aplicar o no, aquel dispositivo de revisión, luego de la necesaria prueba de los hechos.

Sin embargo, debe tenerse en gran consideración que las revisiones de los acuerdos suscriptos, por fundamentos varios (inclusive y principalmente aquellos relacionados a la alteración de las circunstancias), en el día a día forense, no representan un dato significativo y rutinario, ilación ésta que deriva de las más elementales reglas ordinarias de la experiencia común.

Dicho de otra forma, cuando se ultima un contrato, la gran mayoría de las veces, el mismo acaba siendo cumplido por

(uno de los más débiles, económicamente, de la Zona Euro). Ello, sobre todo, en las relaciones contractuales individuales. 
las partes suscriptoras, aunque el ajuste contenga algún tipo de cláusula con contenido leonino o de tipo potestativo.

Existe, entretanto, una parcela de contratantes que escapa a esta regla de la experiencia común. Así, de esta forma, los problemas, ordinarios o extraordinarios, derivados de cualquier relación contractual, normalmente surgen cuando sobreviene el nacimiento ulterior de determinada controversia. Este será el instante en que uno de los contratantes, ciertamente, acabará acudiendo al Poder Judicial para buscar, como mínimo, una solución satisfactoria para sus intereses y pretensiones derivadas del instrumento de marras.

Es en este momento que el juez, caso a caso, decidirá de manera puntual, aplicando o no en caso "sub judice", ciertos institutos y regímenes jurídicos. Ello lo hará conforme el contenido del contrato y de acuerdo con la forma a través de la cual las partes ejecutaron el mismo. Todo esto, teniendo como marco su moldura fáctica.

De esta manera, el magistrado a cargo del juzgamiento de determinada demanda que envuelva cualquier modalidad de contrato, especialmente aquellos de ejecución continuada o diferida, estará provisto de ciertas herramientas, ya existentes en el sistema jurídico vigente, con las que podrá contar para dar la mejor solución al litigio instaurado. Y simplemente, como corolario, aplicará el derecho al caso concreto. 


\subsection{De la revisión de los contratos por alteración de las circunstancias en larga escala en el sistema jurídico argentino}

En la República Argentina, en una circunstancia histórica especial, que temporalmente abarcó el final del siglo $\mathrm{XX}$ y comienzos del siglo $\mathrm{XXI}^{173}$, sobrevino una brutal crisis económica y cambiaria, que afectó en larga escala, de una sola vez y en un específico momento, la economía de un número inconmensurable de contratos vigentes, especialmente los de tipo bancario, relativos sobre todo, a aplicaciones financieras. De ahí el motivo del planteamiento de tan instigante tema, ahora, en el perímetro mayor de la presente investigación) $)^{174} 175$.

173 En términos políticos, tenemos que el país había elegido como Presidente de la República a Fernándo De La Rua en octubre de 1999 (representante de la Unión Cívica Radical, tradicional partido político argentino aliado para esos comicios con el Frepaso, un conglomerado partidiario de centro izquierda). Su gobierno, debido a la crisis en todos los ámbitos (político, económico y social) no resistió y cayó en diciembre del 2001 con su renuncia y huída en helicóptero de la sede del gobierno. Luego de una agitada sucesión con cinco presidentes en dos semanas (que incluyó la presidencia de Adolfo Rodríguez Saa de una semana de duración, quien declara la moratoria de la deuda externa) asume el cargo de primer mandatario el peronista Eduardo Duhalde (electo por el Congreso) que gobernará hasta mediados del 2003 cuando es electo otro peronista, Néstor Kirchner, para el período 2003-2007. Para ahondar más sobre la caída del gobierno radical a fines del 2001 véase BONASSO, MIGUEL, El Palacio y la calle, Planeta, Buenos Aires, 2002.

174 Véase a este respecto, lo expuesto por el jurista argentino CARLOS GHERSI que expresa: "La Argentina, hacia fin del año 2001, se vio envuelta en una "emergencia", y 


\section{Alteración de las Circunstancias y Revisión Contractual}

\section{Esta grave y devastadora crisis}

económica y social, prácticamente, paralizó la economía argentina por

a partir de allí se dictaron una serie de medidas de política económica, derecho económico, derecho cambiario, etc., generando un marco económico-jurídico de inseguridad, inconstitucionalidad en la forma de aplicación y de confiscación (inconstitucionalidad en el contenido de la norma) y hasta una sentencia de contradicción ideológica (por el perfil político) que — desde su contenido - es casi una de las más importantes de la Corte Suprema por su congruencia (las otras fueron: Peralta, Pepsi Cola y Rebesteck, si aludimos al sentido que hemos dado a la frase precedente), y todo ello en menos de dos meses. Es tal la alterabilidad del sistema como tal, que dio lugar a una situación insólita: casi cien mil amparos (de los cuales muchos abogados no informaron a los ciudadanos requirentes que se trata de un juicio y que puede generar costas y tasa de justicia - art. 4 de la Ley 24.240) así como irregularidades (situaciones de obtención de privilegios administrativo-bancarios y judiciales de algunas personas, lo que está dando lugar a investigaciones judicialespenales) e inequidades, que darán lugar a un sinnúmero de futuros pleitos por reparación de daños. En fin, un verdadero infierno" (GHERSI, C., "Reparación de daños contractuales producidos por la emergencia económica”, Nova Tesis, 2002, pp. 19/20).

175 Véase también, ALEJANDRO PEREZ, que aduce en el mismo sentido que "Antes de sancionada la reforma constitucional de 1994, la Corte Suprema ha caracterizado al supuesto fáctico habilitante para el dictado de un decreto de necesidad y urgencia como "una situación de grave riesgo social frente a la cual existió la necesidad de medidas súbitas”. La Corte procura definir la emergencia económico-social en estos términos: "se trata de una situación extraordinaria que gravita sobre el orden económico-social, con su carga de perturbación acumulada, en variables de escasez, pobreza, penuria o indigencia, origina un estado de necesidad al que hay que ponerle fin." (Pérez, Alejandro, "Decretos de necesidad y urgencia - Limites y control”, Depalma, Buenos Aires). 
meses, llevando al Estado Argentino casi a la bancarrota. Su impacto fue tremendo y totalmente negativo sobre los millares de relaciones contractuales entonces existentes. Sus desdoblamientos perversos en el seno de la economía argentina de la época, eran absolutamente imprevisibles.

Aunque el ordenamiento jurídico contase con una herramienta normativa específica (el supra citado art. 1198 del Código Civil Argentino), el legislado argentino entendió correctamente - que dicho mecanismo jurídico sería insuficiente para atender a una demanda en gran escala. Ello, hasta porque el artículo de marras del Código Civil Argentino, conforme su modulado enunciado, da margen para varias interpretaciones relacionadas con su efectiva aplicabilidad (o no), en determinado caso concreto.

De ahí que, a fin de establecer un reglamento de revisión de contratos uniforme en larga escala, de emergencia (no es casualidad que las leyes excepcionales del período quedaron conocidas simplemente como 'leyes de emergencia), el Congreso Nacional de Argentina sancionara leyes especiales con el fin de, emergencialmente, solucionar la grave crisis por la que atravesaba el país a fines de 2001 y comienzos de $2002 .{ }^{176}$. Su trazo esencial era posibilitar que

${ }^{176}$ Las denominadas "Leyes de Emergencia" de Argentina, en el turbulento período citado, se constituyeron en un entramado normativo representado, básicamente, por los siguientes dispositivos legales: a) La Ley ${ }^{\circ}$ 25.561, del 6 de enero de 2002, que trato, en resumen, de la emergencia pública y la reforma del régimen cambiario; b) El Decreto n 1242/02, del 03 de febrero del 2002, que estableció un reordenamiento general y 


\section{Alteración de las Circunstancias y Revisión Contractual}

el juez, en cada caso concreto, de manera uniforme e integradora, pudiese decidir en masa, en larga escala, aplicando conceptos previamente formateados. Los mismos tenían como escenario una alteración macroeconómica de las circunstancias, que se reflejaban en la economía de cada contrato individual formalizado por cada contratante argentino capaz.

En este especialísimo contexto de emergencia, se verificó una inmediata y efectiva intervención estatal en el sistema jurídico argentino, en el ámbito del derecho de las obligaciones. Ello, de forma de establecer reglas más duras tendientes a permitir la inmediata revisión y calibración de los contratos sujetos a las referidas leyes de emergencia ${ }^{177}$.

total del sistema financiero del país; c) El Decreto $n^{\circ}$ 214/02, también del 3 de febrero de 2002, que reglamentó las extinción de la paridad del dólar americano y el peso argentino, vigente desde 1991, por fuerza de la Ley n 23.928 del 27 de marzo de dicho año; y finalmente d) El Decreto $n^{\circ} 762 / 02$, del 15 de febrero del 2002, que impuso un nuevo régimen jurídico relativo a las reglas económicas de estabilización.

${ }^{177}$ Discurriendo sobre la urgente necesidad, frente a las circunstancias de grave crisis económica instalada, de un diálogo normativo válido y eficaz entre las varias normas positivas ante la carta magna argentina, el jurista ALEJANDRO PEREZ sostuvo, en la oportunidad, con gran propiedad que: "Cuando la Constitución, en su nueva redacción, admite el estado de necesidad política como algo posible y que excepcionalmente puede dar lugar al ejercicio de funciones legislativas por el Poder Ejecutivo, toma a dicha causal de justificación en su sentido jurídico. Por tal motivo, en tanto causal de justificación jurídica, debe desenvolverse en un marco normativo que es, precisamente, la Constitución, la cual sirve de sustento al sistema político que se pretende salvar en la emergencia y frente al cual se aspira hacer valer el argumento de causal de justificación del estado de necesidad. Ese marco normativo es la carta magna, porque es a la luz de 
¿Con qué objetivo? Con el concreto fin de calibrar los contratos sujetos al nuevo régimen jurídico de emergencia, adecuándolos, de inmediato, a un nuevo formato económico. Ello, tanto en términos de macroeconomía, como de economía individual de cada contrato de "per se", de manera evitar las graves contradicciones de carácter económico que gravitaban alrededor de los acuerdos sujetos a aquellas leyes de emergencia referidas. ${ }^{178} 179180181$

ella que el Poder Ejecutivo pretende legitimar tanto sus títulos como su acción. Es también en ese marco en que intentará esgrimir su causal de justificación desde el punto de vista técnico-jurídico". (PEREZ, A., "Decretos de necesidad y urgencia - Limites y Control", Depalma, Buenos Aires, 149/150).

${ }^{178}$ A título ilustrativo, verifíquense los siguientes fallos (de la presente nota y ssgtes.), que van de acuerdo con este entendimiento y conforme lo resuelto por la CSJN (Corte Suprema de Justicia de la Nación) de Argentina:

1) Imprevisión contractual - Alcance - "La Teoría de la Imprevisión es mucho más que una teoría, para conformar varios incisos del art. 1198 del Código Civil. Esto último señala, a la vez, que la entronización en un cuerpo legal de tal dispositivo no dejó el campo de actuación de la norma en completa libertad a los jueces y a las partes, sino que - ante la excepción que la cláusula 'rebus sic stantibus' ("así permaneciendo las cosas") consagraba respecto del principio 'pacta sunt servanda' ("somos siervos de los pactos") - aquella quedó reglada en un nada parco precepto". CCI art .1198. CC0102 LP 211795 RSD-117-92 S 4-8-1992, Juez REZZONICO, J. C. (SD). CARATULA: "Polibol S.R.L. c/ Papelera Pacar S.A s/ Cumplimiento de contrato". MAG. VOTANTES: Rezzónico, J. C. - Vásquez. -

179 2) Emergencia económica - Caracteres. "La pesificación de las obligaciones dinerarias contraídas en moneda extranjera no produce una aplicación retroactiva de la 


\section{Alteración de las Circunstancias y Revisión Contractual}

ley, en cuanto por ella se entiende a la que alcanza a los efectos consumados o consolidados de las situaciones anteriores (art. 3 del Cód. Civil), sino una readecuación del contenido sustancial de la obligación dineraria pendiente de cumplimiento o en curso de ejecución a la nueva realidad económica y cambiaria generada por la legislación de emergencia, con destino, precisamente, a paliarla mediante el aporte solidario de todos los sectores sociales. Es en virtud de ello que el nuevo régimen ha preferido mantener la indemnidad del crédito dinerario, cuya cara opuesta es la integridad del pago (arts. 617; 619 y 740 del Cód. Civil) en su concepción valorista, es decir, atándola al valor adquisitivo que tuviera en el origen, a despecho de una concepción nominalista, meramente funcional al régimen anterior (convertibilidad), exigida a ultranza con apoyo en el principio "pacta sunt servanda" e interesado olvido de aquel otro, implícito en todo negocio jurídico, "rebus sic stantibus", que lo moraliza, adecuándolo con justicia al cambio de las circunstancias imperantes cuando éstas desequilibran las equivalencias prestacionales de origen”. CCI Art. 3; CCI Art. 617; CCI Art. 619; CCI Art. 740. CC0002 SM 53893 RSD-431-3 S 23-10-2003, Juez OCCHIUZZI (SD). CARATULA: “Administración Global de Claudio Daniel Díaz c/ Díaz, Claudia Marcela y otros s/ Ejecutivo. MAG. VOTANTES: Occhiuzzi - Scarpati Mares.

180 3) Compraventa - Resolución. "La Teoría de la Imprevisión no puede aplicarse para corregir agravaciones sustancialmente previsibles de aquello a que las partes se obligaron, ya que el principio sigue siempre el cumplimiento estricto de lo pactado, "pacta sunt servanda", pero la lesión sobreviniente, producto de un hecho extraordinario e imprevisible - hiperinflación de 1989 -, hace aplicable la cláusula "rebus sic stantibus", considerada implícita en el contrato.- CC0002 MO 32752 RSD459-94 S 28-12-1994, Juez SUAREZ (SD). CARATULA: "Santagada, Jorge Miguel y Otra c/ Sociedad Civil de Trabajadores Municipales de La Matanza s/ Resolución de Contrato. Nulidad de cláusula y Reintegro de cuota”. MAG. VOTANTES: SUAREZCONDE - CALOSSO. TRIBUNAL DE ORIGEN: JC06.

181 4) Actualización monetaria - Procedencia / Emergencia económica - Actualización monetaria. "Si bien la realidad social o económica de una nación no siempre es fiel reflejo del ordenamiento jurídico que la rige, dada la mutabilidad propia que imprime la 
Desde nuestra perspectiva, por lo tanto, la mayor contribución del Derecho Argentino, en lo que concierne al derecho obligacional en general y a la alteración de las circunstancias en particular, en un período tan especial, se refiere a la notable percepción del legislador argentino. Ello, por saber determinar, en un contexto de grave crisis económica y social, sin precedentes en la historia nacional, parámetros normativos eficaces, en el sentido de establecer, masivamente, nuevas reglas e imposiciones legislativas. No pasibles las mismas de ser

evolución humana, no es menos cierto que la vida en sociedad se desenvuelve -en sistemas republicanos como el nuestro, conforme el art. $1^{\circ}$ C.N.- con apego a la voluntad de los representantes de la soberanía popular. Los mandatos normativos han sido los pilares sobre los que se han construido con el tiempo conciencias sociales básicas en torno al alcance y extensión de determinados derechos, acuerdos o soluciones de transacción que en más de una oportunidad han permitido obtener resultados de bienestar general que de otro modo podrían verse frustrados". CON Art. 1. SCBA, C 93323 S 14-10-2009, Juez SORIA (OP). CARATULA: "Casuscelli de Estévez, Dominga y Otro c/ Municipalidad de La Matanza y otro s/ Daños y perjuicios. MAG. VOTANTES: Kogan - Genoud - De Lázzari - Soria - Negri. TRIB. DE ORIGEN: CC0002MO. 5) Actualización monetaria - Procedencia // Emergencia económica Actualización monetária. “ (... El poder de los jueces debe ejercerse en vista a aquellos mandatos y circunscripto al conflicto que los litigantes promueven ante sus estrados, y ello importa al sentenciar un acotamiento del margen de acción pues - de un lado- demanda prescindir de meras valoraciones genéricas sobre el contexto social o económico y -del otro- requiere de un preciso escrutinio de los elementos que conforman las "circunstancias" del caso a resolver". CON Art. 1. SCBA, L 90259 S 116-2008, Juez SORIA (OP). CARATULA: “Agüero, Benita Encarnación c/ Hospital Regional Español s/ Indemnización despido”. MAG. VOTANTES: Soria - PettigianiKogan -Genoud - Hitters. TRIB. DE ORIGEN: TT0001BB. 


\section{Alteración de las Circunstancias y Revisión Contractual}

moduladas o interpretadas por los magistrados de forma más suave, a fin de dar una solución, a corto plazo, a la crisis económica padecida. ${ }^{182}$

Esto fue posible por la feliz conjugación de la real voluntad del legislador en aquel especial momento histórico (triunfo de su voluntad) y la convalidación, por parte de la jurisprudencia argentina posterior, de esta posibilidad de revisión contractual por alteración ulterior de las circunstancias en larga escala.

En esta línea de pensamiento, la intervención por parte del Estado Argentino, prácticamente de un día para el otro, en la economía de los contratos en curso, guarda estrecha relación con las ideas de la doctrina de la intervención estatal, propuesta por el jurista francés LOUIS JOSSERAND, sin embargo, con una visión

\footnotetext{
${ }^{182}$ Obsérvese, una vez más, la académicamente rigurosa posición de CARLOS GHERSI al respecto: "El ajuste realizado a través de estos coeficientes puede llevar a que, al momento del cumplimiento de la obligación, es decir el pago, el valor resultante de la cosa, bien o prestación fuere superior o inferior al pactado, en cuyo caso cualquiera de las partes puede solicitar un reajuste equitativo, conforme el procedimiento que prevé el art. 8 del Decreto 214/ 02. Sin embargo, tal procedimiento no siempre resulta adecuado y debemos considerar las distintas posibilidades". (GHERSI, C., "Reparación de daños contractuales producidos por la emergencia económica”, Nova Tesis, Buenos Aires, 2002).
} 
Alteración de las Circunstancias y Revisión Contractual

nítidamente más avanzada, desde el punto de vista de la función social de los contratos. ${ }^{183}$

183 Véase nuevamente, JOSSERAND, L., "Tendences actuelles de la Théorie dés Contracts”, RT, 1937, p. 21 y ssgtes. 


\section{CAPÍTULO VI}

1. Diálogo jurisprudencial: recortes de la jurisprudencia de Brasil y de España - Jurisprudencia Comparada

1.1. La Teoría de la Imprevisión en el Derecho Español

1.2. Aplicación de la Teoría de la Imprevisión en el ámbito de Brasil: algunos fallos que adoptaron esta teoría como razón de decidir 


\section{DIÁlOGO JURISPRUDENCIAL: RECORTES DE LA JURISPRUDENCIA DE BRASIL Y ESPAÑA. JURISPRUDENCIA COMPARADA}

\subsection{La Teoría de la Imprevisión en el Derecho Español}

El derecho positivo español no contempla, normativamente, la posibilidad de revisión del contrato por alteración sobreviniente de las circunstancias. No obstante, el instigante tema ha sido, aunque tímidamente, enfrentado por parte de la doctrina española civilista, destacándose los siguientes doctrinarios: ROCA SASTRE, MANUEL ALBALADEJO, LUIZ DIEZ PICAZO y PONCE DE LEÓN, FEDERICO DE CASTRO Y BRAVO, CARLOS LASARTE ÁLVAREZ, MARGARITA CASTILLA BAREA, JOSÉ ANTONIO MARTIN PÉREZ, y LUZ M. MARTINEZ VELENCOSO, entre otros. ${ }^{184}$

\footnotetext{
${ }^{184}$ ROCA SASTRE, “Estudios de Derecho Privado”, Vol. I, Cap. VII, "El problema de la alteración das circunstancias", elaborado con la colaboración de JOSÉ PUIG BRUTAL, Madrid, 1948, p.235; ALBALADEJO, M., "Compendio de Derecho Civil”, subsección $3^{\circ}$., "Modificacion del contrato por alteración de las circunstancias", Edisofer, Madrid, 2007; DIEZ PICAZO y PONCE DE LEÓN, L., "Extinción de obligaciones", Director JOSÉ RAMÓN FERRANDIZ GABRIEL, "La cláusula rebus sic stantibus”, Consejo General del Poder Judicial, Madrid, 1996; DE CASTRO Y BRAVO, F., “Derecho Civil de España”, Vol. III, "El negocio jurídico y la persona jurídica”, parágrafo, 382, "La cláusula 'rebus sic stantibus', Thomson Civitas, 2008; LASARTE ÁlVAREZ, C., "Princípios de Derecho Civil”, T III, Contratos, 4., "La alteración de las circunstancias contractuales: La cláusula 'rebus sic stantibus", Trivium editor; CASTILLA BAREA, M., "La imposibilidad de cumplir los contratos", III.4. -
} 
A la par del campo doctrinario, también la jurisprudencia del Reino de España, de forma excepcional, en términos históricos, en algunos casos, ha adoptado el entendimiento que refrenda la aplicación de la cláusula "rebus sic stantibus", en sus varios matices, para permitir la revisión del contrato. La valoración interpretativa de algunos recortes da jurisprudencia del Tribunal Supremo Español convergen, de sobremanera hacia tal entendimiento.

Tímidamente - ciertamente porque, hasta este momento histórico, el sistema legal positivo español no contempla la revisión contractual por la alteración de la circunstancias - los fallos del país tratan puntualmente del asunto, adoptan posiciones incompatibles. A veces acogiendo la posibilidad de revisión del instrumento por la alteración sobreviniente, otras rechazando la pretensión estribados en la aplicación de la cláusula "rebus sic stantibus".

Un interesante y pedagógico caso, en esta línea de divergencia de la jurisprudencia española, dice respecto a una demanda relativa a un contrato de promesa de venta y desvalorización posterior de la moneda, donde el Tribunal Supremo en el caso "Vilarrasa

\footnotetext{
'La excesiva onerosidad de la prestación"; MARTIN PÉREZ, J.A., "La rescisión del contrato" - "En torno a la lesión contractual y el fraude de acreedores", Bosch, Barcelona, 1995; MARTINEZ VELENCOSO, L.M., "La alteración de las circunstancias contractuales", Thomson Civitas, 2003.
} 
Sierra contra Llord Fernández", del 5 de junio de 1945, entendió que no era posible la alteración del contrato originario. ${ }^{185}$

Sobre el asunto, otra importante decisión, en el mismo sentido, dice respecto a una tormentosa cuestión que envolvió pacto de usufructo y obligación facultativa, el "case" "Duarte García y otros c/ Bueno Carrión y Gamero-Bueno", del 21 de octubre de 1958. Aquí también se optó por la no aplicación de la cláusula "rebus sic stantibus". 186

En otra senda, tenemos una interesante decisión del mismo Tribunal Supremo, pero en sentido opuesto. Es decir, aplicando el entendimiento relacionado con la revisión contractual en virtud de la sobreviniencia de una alteración de las circunstancias. Ello tuvo lugar con un contrato donde una de las partes se comprometía a suministrar a la otra una fuerte cantidad de envases litografiados, por el precio y de las características que se detallaban. La alteración de las circunstancias vino dada por la sobreviniencia de la Guerra Civil Española (1936 - 1939). (“case" "Vega Gorostegui c/ Pérez Del Reio", del 17 de mayo de 1957). ${ }^{187}$

185 El caso aquí referido fue colacionado por el catédrático DIEZ- PICAZO, L., in “Estudios sobre la jurisprudencia civil”, Vol. I, Tecnos, Madrid.
186 Idem
187 Idem. 
Todavía en la misma línea de

posibilidad de revisión del instrumento por alteración sobreviniente de la situación, otro interesante y erudito fallo provino también del Tribunal Supremo. El tema derivaba una cuestión contractual que discutía usufructo y devaluación de la moneda (“case" "Boroix Martinez c/ Calvo de León”, del 23 de noviembre de 1962) ${ }^{188}$.

Por lo tanto, el estudio sistemático de estas decisiones apunta, como eslabón común de referencia, al carácter de excepcionalidad que revestía la posibilidad de dejar de lado el pacta sunt servanda, en los casos analizados por la Suprema Corte del país.

Aún no habiendo norma expresa autorizando la potencial revisión de lo que fue contratado, se reconoció, sin embargo, la existencia de situaciones absolutamente imprevisibles. Éstas conspiraban contra el mantenimiento de la base económica - negocial de los acuerdos en pauta y como visto, fueron concretamente revistos en el ambiente de la justicia estatal.

Otro punto importante, que merece registro, a pesar de ser reiterativo, sobre el análisis sistemático de estos recortes de jurisprudencia ínsitos en la doctrina de las sentencias españolas sobre el tema es el siguiente. La máxima instancia judicial española, siempre que acataba la posibilidad de revisión, lo hacía relacionando la autorización jurisdiccional modificatoria a algo puntalmente excepcional,

188 Idem. 
singular y único, a fin de justificar, como corolario, la especial postura adoptada.

Esta postura, todavía es adoptada en forma puntual, destacándose a fines ejemplificativos, la memorbalbe sentencia del 12/11/2004 que tuvo por objeto una interesante demanda relativa a una cesión de derechos correspondientes a un agente de seguros y su cartera a cambio de una renta. ${ }^{189} 190$

189 Sentencia del 12/11/2004 (RJ 2004, 6900) Objeto: cesión de derechos correspondientes a agente de seguros y de cartera de seguros a cambio de una renta. Invalidez (no se aprecia) por error; por indeterminación del objeto. Cláusula "rebus sic stantibus". Partes: D. Domingo y $\mathrm{D}^{\mathrm{a}}$ Lina, contra D $\mathrm{D}^{\mathrm{a}}$ Verónica y D. Gustavo (recurrentes). Ponente: Exmo. Sr. D. Pedro González Poveda. Fallo: Estimatorio del recurso. No existe indeterminación en las prestaciones de un contrato cuando no resulta necesario celebrar un nuevo acuerdo para la determinación del objeto contractual. Cláusula "rebus sic stantibus", exposición de la doctrina jurisprudencial: A) La cláusula "rebus sic stantibus" no está legalmente reconocida; B) Sin embargo, dada su elaboración doctrinal y los principios de equidad a que puede servir, existe una posibilidad de que sea elaborada y admitida por los Tribunales; C) Es una cláusula peligrosa y, en su caso, debe admitirse cautelosamente; D) Su admisión requiere como premisas fundamentales: a) alteración extraordinaria en el momento de cumplir el contrato en relación con las circunstancias concurrentes al tiempo de su celebración; b) una desproporción exorbitante, fuera de todo cálculo, entre las prestaciones, y c) que todo ello acontezca por la sobreviniencia de circunstancias imprevisibles; y E) En cuanto a sus efectos, hasta el presente, le ha negado los rescisorios, resolutorios o extintivos del contrato otorgándole los modificativos del mismo, encaminados a compensar el desequilibrio de las prestaciones. No procede aplicar la cláusula "rebus sic stantibus", ni puede hablarse de restaurar el equilibrio entre las mutuas prestaciones de los contratantes cuando la que corresponde a una de las partes ya ha sido cumplida. 
Actualmente, como fue expresado, el Código Civil Español continúa no autorizando la revisión contractual por alteración de las circunstancias de forma expresa en su legislación, dejando esa labor para los órganos jurisdiccionales respectivos en cada caso puntual, como pudo ser observado a través de las setencias y jurisprudencia citada supra.

${ }^{190}$ En el mismo sentido preconizado por la excelsa doctrina jurisprudencial española a través de su máxima Corte, son de interés observar los fallos colacionados por MANUEL MEDINA DE LEMUS, que comenta sobre el tema: "Esta materia tan tratada por la doctrina y tema específico de las oposiciones a notarías y abogados del Estado de los años cincuenta y sesenta, que en realidad fue aceptada por la jurisprudencia apenas en un par de casos durante medio siglo, empezó a aplicarse con mayor oportunidad, toda vez que en los tiempos modernos son mucho más cambiantes las circunstancias y además en menos tiempo, por la vertiginosidad del tráfico diario, el acortamiento de las comunicaciones y la mayor densidad de contratación. Hoy, por citar una de las más modernas sentencias, la STS del 4 febrero 1995 (Ar. No 739), recordada entre otras muchas, reverdece los requisitos necesarios del supuesto: “...reiterada doctrina de esta Sala. Sentencias de 6 octubre 1987 (Ar. No 6720), 16 octubre 1989 (Ar. 6927), 26 octubre y 10 diciembre 1990 (Ar. No 8049 y 99270, 23 abril y 8 julio 1991 (Ar. No 3023 y 5376), 6 noviembre 1992 (Ar. $\mathrm{N}^{\circ}$ 9226) y 24 junio 1993 (Ar. $\mathrm{N}^{\mathrm{o}}$ 5382), entre otras muchas, con arreglo a la cual para que la cláusula "rebus sic stantibus" pueda ser tenida en cuenta (aunque siempre con una gran cautela, pro la alteración que ello pude suponer del principio "pacta sunt servanda" y del seguridad jurídica) se requiere la inexcusable concurrencia conjunta de los siguientes requisitos: a) alteración completamente extraordinaria de las circunstancias en el momento de cumplir el contrato en relación con las concurrentes al tiempo de su celebración; b) una desproporción inusitada o exorbitante entre las prestaciones de las partes contratantes, que rompan el equilibrio entre dichas prestaciones; c) que todo ello acontezca por la sobreviniencia de circunstancias radicalmente imprevisibles." (MEDINA DE LEMUS, M. - "El Derecho Civil Español en los últimos 50 años”, Centro de Estudios Registrales, Madrid, pp. 199/200). 
Sin embargo, tenemos conocimiento que actualmente, tramita, en la esfera legislativa del Reino de España, una propuesta normativa elaborada por la Comisión General de Codificación para la reforma del libro cuarto del Código Civil Español, que introduce, normativa y expresamente, en el ordenamiento jurídico positivo de la península, la posibilidad de revisión del contrato debido a la alteración sobreviniente de las circunstancias, comprobada la destrucción de la propia base del negocio originario, es decir las bases del negocio cuando éste fue concluido. ${ }^{191} 192$

191 Por la referida propuesta, se introduce el capítulo VIII "De la alteración extraordinaria de las circunstancias básicas del contrato", del Código Civil Español, una nueva norma jurídica, con una propuesta de redacción, vinculada con la cuestión de la alteración de las circunstancias, con el siguiente enunciado: "Si las circunstancias que sirvieron de base al contrato hubieran cambiado de forma extraordinaria e imprevisible durante su ejecución de manera que ésta se haya hecho excesivamente onerosa para una de las partes o se haya frustrado el fin del contrato, el contratante al que, atendidas las circunstancias del caso y especialmente la distribución contractual o legal de riesgos, no le sea razonablemente exigible que permanezca sujeto al contracto, podrá pretender su revisión, y si ésta no es posible o no puede imponerse por una de las partes, podrá aquél pedir su resolución. La pretensión de resolución solo podrá ser estimada cuando no quepa obtener de la propuesta o propuestas de revisión por cada una de las partes una solución que restaure la reciprocidad de intereses del contrato" (Sugerencia de texto publicada en el Boletín de Información del Ministerio de Justicia de enero de 2009).

${ }^{192}$ La sugestión del texto, en al redacción de la norma, está construida de la siguiente forma: "Artículo 6:111: Cambio de circunstancias: (1) Las partes deben cumplir con sus obligaciones, aun cuando les resulten más onerosas como consecuencia de un aumento en los costes de la ejecución o por una disminución del valor de la contraprestación que 
Este feliz cambio de punto de vista, por parte del legislador español, ciertamente, está buscando afinarse y consubstanciarse con las nuevas directrices comunitarias europeas, teniendo en vista que, en el actual Código de Obligaciones de la Comunidad Europea, producido por la Comisión Lando, hay expresa previsión de aplicación de dispositivos jurídicos relacionados con el régimen jurídico de revisión de los contratos en virtud de la alteración de las circunstancias.

se recibe. (2) Sin embargo, las partes tienen la obligación de negociar una adaptación de dicho contrato o de poner fin al mismo si el cumplimiento del contrato resulta excesivamente gravoso debido a un cambio de las circunstancias, siempre que: (a) Dicho cambio de circunstancias haya sobrevenido en un momento posterior a la conclusión del contrato. (b) En términos razonables, en el momento de la consunción del contrato no hubiera podido preverse ni tenerse en consideración el cambio acaecido. (c) A la parte afectada, en virtud del contrato, no se le pueda exigir que cargue con el riesgo de un cambio tal de circunstancias. (3) Si en un plazo razonable las partes no alcanzan un acuerdo al respecto, el juez o tribunal podrá: (a) Poner fin al contrato en los términos y fecha que considere adecuado. (b) $\mathrm{O}$ adaptarlo, de manera que las pérdidas y ganancias resultantes de ese cambio de circunstancias se distribuyan entre las partes de forma equitativa y justa. En cualquiera de los casos, el juez o tribunal podrá ordenar que la parte que se negó a negociar; o que rompió dicha negociación de mala fe, proceda a reparar los daños causados a la parte que sufrió dicha negativa o dicha ruptura". (Sugerencia de texto publicada en el Boletín de Información del Ministerio de Justicia de enero de 2009). 


\subsection{Aplicación de la Teoría de la Imprevisión en el ámbito de Brasil: algunos fallos que adoptaron esta teoría como razón de decidir}

En Brasil, hasta la llegada del Código de Defensa del Consumidor, en 1990 (Ley n ${ }^{\circ}$ 8078, del 11 de Septiembre de 1990, que dispuso sobre la protección del consumidor y disciplinó las relaciones contractuales de consumo), no había norma legal (derecho positivo) disciplinando la posibilidad de revisión de los contratos, por la invocación de la teoría de la imprevisión. Su aplicación era esporádica y fragmentada, teniendo por base, fundamentalmente, lecciones doctrinarias extranjeras.

En aquel año, sin embargo, el legislador brasileño, adoptando la tendencia mundial en ese sentido, relacionada con contratos que involucrasen relaciones de consumo, autorizó la aplicación de dicha teoría, que pasó a ser disciplinada, normativamente, en el art. $6^{\circ}$ inciso V, del apuntado Código de Defesa del Consumidor: "son derechos básicos del consumidor: (...) inciso V - la modificación de las cláusulas contractuales que establezcan prestaciones desproporcionales o su revisión en razón de hechos sobrevinientes que las tornen excesivamente onerosas".

Posteriormente fue dicha teoría receptada en el nuevo Código Civil brasileño de 2002 (Ley n ${ }^{\circ}$ 10.406, del 10 de enero de 2002), donde, en el art. 478, se contempló, concretamente, la posibilidad da resolución del contrato por onerosidad excesiva, rompiendo, en aquel momento, en términos normativos, con el absolutismo 
contractual que, hasta entonces, en el sistema jurídico nacional brasileño (con excepción, como visto supra, de los contratos relativos a relaciones de consumo, con disciplina jurídica propia desde 1990), se conectaba con los postulados ortodoxos de la cláusula "pacta sunt servanda", especialmente en los contratos relacionados con el Derecho Civil y Empresarial (Derecho Comercial), hasta porque, anteriormente, en el Código Civil derogado (de 1916), no había previsión para la aplicación de la referida teoría. ${ }^{193}$

El dispositivo supra mencionado, teniendo en vista su clara redacción, señala, en última instancia, la posibilidad de resolución del pacto, siempre que la base del negocio jurídico originario, por contingencias imprevisibles, sufre un desequilibrio y una flagrante desproporción. Además, con la puesta en vigor del nuevo Código Civil del Brasil, tuvo lugar una robusta aproximación de principios entre el citado nuevo "codex" civil y el mencionado Código de Defensa del Consumidor, especialmente en lo referente a la regulación contractual y mecanismos de revisión, una vez que ambos, en definitiva, son incorporadores de una nueva teoría general de los contratos, con un notable perfil de vanguardia, en especial en relación a la flexibilización de la cláusula "pacta sunt servanda".

A fin de proveer una explicación más clara, se transcribe, seguidamente, el entero tenor del artículo supra mencionado, "in verbis": “Art. 478: En los contratos de ejecución continuada o diferida, si la prestación de una de las partes se torna

${ }^{193}$ En Brasil, por lo tanto, podemos decier que la Teoría de la Imprevisión salió del plano doctrinario y llegó al plano legal. 
excesivamente onerosa, con extrema ventaja para la otra, en virtud de acontecimientos extraordinarios o imprevisibles, podrá el deudor pedir la resolución del contrato. Los efectos da sentencia a decretar serán retroactivos a la fecha de la citación".

La jurisprudencia del Superior Tribunal de Justicia de Brasil, es referencia mayor en el ámbito de la uniformización de sentencias en los Estados de la Federación ${ }^{194}$. Esta Corte, que posee la incumbencia constitucional y jurisdiccional de interpretar las normas positivas, de estatura infraconstitucional, siguiendo un posicionamiento jurisprudencial histórico, siempre adoptó la tesis de posibilidad de aplicación de la Teoría de la Imprevisión. Ello desde el propio momento de su efectiva creación, ocurrida en 1988 (a pesar de no poseer autorización normativa hasta la llegada del Código Civil de 2002), teniendo como meta el mantenimiento objetivo de la base del negocio jurídico originariamente entablado. Lo que quedó plasmado, a partir del año 2002 (por la sanción de la nueva legislación civil del país), en el art. 422 del mismo "codex", que consagra la aplicación de los postulados de la buena fe para cualquier tipo de contrato, merced al enunciado que determina que "los contratantes son

\footnotetext{
${ }^{194}$ En Brasil, los Estados miembros de la Federación mantienen, cada uno, un Tribunal de Justiça (Tribunal de Justicia, segundo grado de jurisdicción). Conforme la actual Constitución Federal de 1988, se creó el denominado Superior Tribunal de Justiça (Superior Tribunal de Justicia), con estatus de Corte Especial (representa la última instancia de la justicia brasileña para las demandas que gravitan en torno a causas infraconstitucionales, no relacionadas directamente a la Carta Magna), y que tiene la incumbencia, entre otras atribuciones de tipo constitucional, de uniformizar la interpretación de la Ley Federal en todo el territorio nacional, siguiendo los principios constitucionales, el Derecho Positivo y el Estado de Derecho.
} 
obligados a guardar, así en la conclusión del contrato, como en su ejecución, los principios de probidad y buena fe".

La orientación de aplicación irrestricta de la cláusula general de buena fe, galvanizada a la disposición general que, igualmente, autoriza la resolución del contrato por onerosidad excesiva, probado hecho posterior de naturaleza imprevisible, toma en cuenta el sistema general del Código Civil y las correspondientes conexiones sistemáticas con otros estatutos normativos y factores metajurídicos.

Desde esta perspectiva, varios son los fallos del Superior Tribunal de Justicia que autorizan la revisión judicial del contrato, siempre que sobrevenga una alteración fundamental de las circunstancias, de forma que se altere, sustancialmente, la propia base del negocio jurídico.

Se destaca, por ejemplo, el fallo de la $4^{\mathrm{a}}$ Sala del Superior Tribunal de Justicia, que, en causa relativa al cobro de mensualidad escolar, aplicó los postulados de la revisión del contrato para el mantenimiento de la base objetiva del negocio jurídico, a fin de mantener el equilibrio de las prestaciones asumidas por las partes, "in verbis": "Base objetiva del negocio jurídico. Equilibrio y proporcionalidad de las prestaciones. Proporcionalidad no exacta. Mensualidad escolar. Matrícula en una disciplina y cobro de semestralidad integral. Debe ser respetada la equivalencia entre la prestación cobrada del alumno y la contraprestación 
ofrecida por la escuela. Si falta apenas una disciplina a ser cursada, no puede ser exigido el pago del semestralidad integral, aunque no se exija en este caso la exacta proporcionalidad". ${ }^{195}$

En otro caso muy interesante, el mismo Superior Tribunal de Justicia, analizando un contrato de compra y venta de cosa mueble, cuyo pago de precio fue acordado en prestaciones / cuotas, entendió ser posible la correspondiente revisión, teniendo en cuenta una alteración económica sobreviniente, imprevisible y de forma ulterior, en el curso de la ejecución del contrato respectivo (desvalorización de la moneda, derivada de galopante inflación, notificadora de la alteración sustancial de la base de la economía del contrato), que modificó la base jurídico-económica del negocio originario, “in verbis": Base objetiva del negocio jurídico. Revisión contractual. Acción de modificación de contrato. Hecho previsible o no. Celebrado contrato de compraventa, con prestaciones diferidas, sin cláusula de corrección monetaria, durante el tiempo de vigencia del Plan Cruzado, cuando se esperaba derrotar a la inflación, la sobreviniente desvalorización de la moneda justifica la revisión del contrato, cuya base objetiva quedó sustancialmente alterada, para actualizar las prestaciones / cuotas de modo que reflejen la inflación acontecida después de la celebración del negocio". 196

195 “In” Superior Tribunal de Justicia de Brasil, 4 Sala, Recurso Especial de Minas Gerais n 334837, Relator Ministro Ruy Rosado de Aguiar, fallo del 12/03/2002.

196 “In” Superior Tribunal de Justicia de Brasil, 4. Sala, Recurso Especial n ${ }^{\circ} 135151$ de Río de Janeiro, relator Ministro Ruy Rosado de Aguiar, fallo del 08/10/1997 
En el mismo nivel, otro importante fallo en dicho sentido de aquella Corte, que, en un caso análogo, discutió acerca de la posibilidad de revisión del contrato por causa del surgimiento ulterior de factor económico imprevisto (inflación), capaz, en definitiva, de llevar a la ruina a uno de los contratantes, "in verbis": base objetiva del negocio jurídico. Intervención judicial en la voluntad de contratar. Previsibilidad de inflación. La inflación es un hecho previsible, pero eso no impide que pueda ser tomada como causa para la modificación o extinción contractual, cuando sus índices vengan a desnaturalizar la obligación, o cuando son adoptados porcentajes diversos para la actualización de los rendimientos del deudor y para sus obligaciones, inviabilizando los pagos. No viola la ley, por lo tanto, la decisión judicial que atiende a tales hechos y les da eficacia en el ámbito del contrato". 197

Otra relevante sentencia, de este tenor, del insigne Tribunal de Justicia del Estado de São Paulo, también analizando un contrato que tuvo su base jurídico-económica alterada, por motivo de las extraordinarias mudanzas cambiarias en la economía, pondera que la posibilidad de la alteración de las prestaciones debidas siempre es posible, probada la imprevisibilidad en el caso concreto, "in verbis": "en razón de la brusca mudanza de la política cambiaria por parte del gobierno, que abandonó el sistema de bandas y provocó un imprevisible aumento de la cotización del dólar norteamericano y de las prestaciones de arrendamiento mercantil a él vinculadas, a mediados de enero de 1999,

197 “In” Superior Tribunal de Justicia de Brasil, 4a Sala, Recurso Especial de Amazonas n ${ }^{\circ}$ 73370, Relator Ministro Ruy Rosado de Aguiar, fallo del 21/11/1995. 
configurando onerosidad excesiva para el deudor, hay que sustituir el criterio de reajuste de las prestaciones por el INPC (factor de actualización monetaria) del IBGE (Instituto Brasileño de Geografía y Estadística), restaurando el equilibrio contractual, con base en la teoría de la imprevisión y en el artículo 6º $6^{\circ}$, del Código de Defensa del Consumidor)." ${ }^{, 198}$

Esta orientación, relacionada con una situación concreta de invocación de la teoría de la imprevisión por causa de cambios radicales macroeconómicos en la economía brasileña, surgidas en el escenario político-económico nacional de manera absolutamente imprevisible, destruyendo la base del negocio de centenas de contratos entonces firmados en el territorio nacional, derivados de la alteración de la tasa de cambio ocurrida en el año 1999, llevó al mencionado Superior Tribunal de Justicia de Brasil, pacificando la cuestión, a autorizar la revisión de los contratos con cláusula de corrección cambiaria por la variación del dólar norteamericano, por la aplicación de la cláusula "rebus sic stantibus", siendo ejemplo contundente el fallo de la $3^{\text {a }}$ Sala de aquel insigne tribunal, que dijo, "in verbis": "la desvalorización de la moneda nacional frente a la moneda extranjera que sirvió de parámetro al reajuste contractual, por ocasión de la crisis cambiaria de enero de 1999, presentó un grado expresivo de oscilación, al punto de caracterizar la onerosidad excesiva que impide al deudor solventar las obligaciones pactadas.

\footnotetext{
198 “In” Tribunal de Justicia de Sao Paulo, apelación civil con revisión n 61863400/9/Sep., $5^{a}$ Cámara, Relator Camarista Dirceu Cintra.
} 
Onerosidad excesiva caracterizada. Buena fe objetiva del consumidor y derecho de información" 199

También en esa misma línea, se verifica como significativo el fallo de la $3^{\text {a }}$. Sala del citado Superior Tribunal de Justicia, en caso concreto que también involucró alteración sustancial de la base del negocio en contrato de arrendamiento mercantil: "la onerosidad excesiva puede dar ocasión a la revisión contractual. 1. Precedente de la Corte asentó que el aumento del dólar norteamericano en el mes de enero de 1999 representa hecho sobreviniente capaz de posibilitar la revisión contractual, en los términos del Código de Defensa del Consumidor (CDC), artículo $6^{\circ}$, inciso $\mathrm{V}$, ya que, de modo indudable, hizo excesivamente onerosa la prestación contractual. $2^{\circ}$ Recurso especial no merituado.,200

También en el mismo sentido, tenemos el interesante plenario de la $3^{\text {a }}$ Sala de aquel mismo notable tribunal, que, en contrato de arrendamiento mercantil, sustentó ser posible la buscada revisión, teniendo en vista el sobrevenir de onerosidad contractual excesiva, en el curso del mismo contrato, por causa de alteraciones cambiarias profundas, en el escenario económico de la época, que vinieron

\footnotetext{
199 “In” Superior Tribunal de Justicia, 3 a Sala, Agravio Regimental en Recurso Especial $\mathrm{n}^{\circ} 374.351$ de Rio Grande do Sul, Relatora Ministra Nancy Andrighi, fallo del $30 / 04 / 2002$.
}

200 "In" Superior Tribunal de Justicia, 3". Sala, recurso especial de Minas Gerais $\mathrm{n}^{\circ}$ 327.250, relator Ministro Carlos Alberto Menezes, fallo del 27/05/2002). 
a afectar, de sobremanera, el valor mensual de las prestaciones debidas, causando, con eso, un desequilibrio contractual insoportable, para justificar la calibración de lo que fuera anteriormente acordado ("Procesal civil y civil. Revisión de contrato de arrendamiento mercantil ("leasing"). Recurso especial. Nulidad de cláusula por ofensa al derecho de información del consumidor. Fundamento inatacado. Indexación en moneda extranjera (dólar). Crisis cambiaria de enero de 1999 - Plan Real. Aplicabilidad del artículo $6^{\circ}$, inciso V, del Código de Defensa del Consumidor. Onerosidad excesiva caracterizada. Buena fe objetiva del consumidor y derecho de información. Necesidad de prueba da captación de recurso financiero proveniente del exterior. Recurso especial. Nuevo examen de prueba. Interpretación de cláusula contractual.,"201

De esta forma, a través de un análisis, hasta superficial, de los fallos expuestos supra, se verifica, plenamente, que la motivación mayor de la posibilidad de revisión reside, básicamente, en la alteración sustancial e imprevisible de la economía del contrato, con incuestionable destrucción de su base, de forma que oprime a uno de los contratantes de manera absurda e injusta, hecho no tolerado por el derecho positivo ni por la jurisprudencia, máxime aplicándose, como es siempre de rigor, los dictámenes de la buena fe y probidad, presentes en los principales sistemas jurídicos.

201 “In" Superior Tribunal de Justicia, 3 $3^{\mathrm{a}}$ Sala, Agravio Regimental en Recurso Especial de Rio Grande do Sul n 374.351, Relator Ministro Ari Pargendler, fallo del 30/04/2002. 
En definitiva, la posición de la jurisprudencia brasileña, en cotejo con la jurisprudencia española sobre el asunto, se presenta más flexible y modulada en la primera. Ciertamente porque el juez brasileño - a diferencia del ibérico - posee ahora una, específica herramienta normativa que le posibilita la revisión de los contratos con base en norma expresa del sistema (Código de Defensa del Consumidor y Código Civil). 
Alteración de las Circunstancias y Revisión Contractual

\section{CONCLUSIONES}




\section{CONCLUSIONES}

\section{- I -}

El moderno Derecho de los Contratos, actualmente, debe basarse en tres puntos fundamentales, en el siguiente orden: a) aspecto ético (buena fe objetiva de conducta de los contratantes, caráctero social (función social del contrato) y operabilidad (perspectiva utilitarista y pragmática de los acuerdos).

\section{- II -}

La buena o mala fe contractual, en última instancia, representa un estado de consciencia del contratante, teniendo como telón de fondo la función social de los contratos. Obrando de buena fe en los primordios de la contratación, no habrá oposición a una eventual ulterior calibración del contrato. Ello, de forma de rescatar, mínimamente, la economía del mismo, hasta porque como surge 
claramente, nadie puede ganar más por el incumplimiento del contrato que con su regular cumplimiento.

La cláusula de la posibilidad de revisión por onerosidad excesiva se encuentra siempre implícita en los contratos de ejecución continuada o diferida, siendo intrínseca a cualquier pacto, a ejemplo de la cláusula de evicción.

La autonomía de la voluntad no debe ser vista como un valor absoluto en sí mismo (ya que, como fue meridianamente expresado, ninguna regla de de derecho posee valor absoluto), sino como un valor que debe estar siempre sujeto a la cláusula general de buena fe, que no puede ser dejada de lado en ningún tipo de contrato. 
Las relaciones jurídicas obligacionales, en la posmodernidad, con énfasis en los contratos de ejecución continuada o diferida, contienen una plausible y previsible inseguridad, que puede desembocar en una ausencia casi total de seguridad jurídica ulterior, considerando la fluidez de las relaciones sociales inherentes al hombre contemporáneo. De ello, deriva la necesidad, en el ámbito contractual, de establecer reglas claras para su revisión y calibración, si sobreviene, durante la ejecución del contrato, una excesiva onerosidad.

Este derecho de revisión (o de deshacer, sin gravamen, el vínculo contractual originario, no siendo posible el rescate del equilibrio económico primitivo entre las partes), representa, para el contratante en desventaja, un derecho fundamental derivado de valores deontológicos y éticos del ser humano, en la medida en que el pacto, siendo ley entre los firmantes, debe siempre atender a los fines sociales más elevados (función social do contrato), a la buena fe y a las exigencias medias del bien común, que derivan de los principios mayores de la dignidad humana, de la legalidad, de la buena fe, de la moralidad y de la 
razonabilidad. Debe tenerse por objeto, por lo tanto, evitar y rechazar las desigualdades supervinientes que puedan con mayor o menor intensidad, desequilibrar la economía del contrato.

En la alteración de las circunstancias, no está en juego la imposibilidad absoluta de la prestación, sino su excesiva onerosidad, siempre teniendo en cuenta, que la situación fáctico-concreta, derivada del contrato respectivo, no puede estar alcanzada por los riesgos inherentes al propio contrato suscripto.

También es importante resaltar que la sobreviniencia en el contrato de la alteración de las circunstancias no puede ser causada por acto, positivo o comisivo, de uno de los contratantes, en 
medida en que colisiona con los postulados de la buena fe la posibilidad de la parte invocar, como factor objetivo para el desbaratamiento del vínculo por cambio de las circunstancias, la alteración que él mismo habría provocado.

La revisión del contrato puede derivar de una determinación explícita (inserción, desde la suscripción, en el contrato, de la cláusula de "hard ship", o existencia de normatización en el sistema jurídico positivo) o implícita, caso de inexistencia de cláusula de "hard ship" en el pacto respectivo y falta de previsión objetiva sobre el tema en el ordenamiento jurídico, pero que, sin embargo, siempre puede ser invocada por el contratante en desventaja, merced a las referencias de principios derivadas de la buena fe contractual y de la función social de los contratos. 
La cláusula "rebus sic stantibus" posee como fundamento mayor, conforme fue visto exhaustivamente, la posibilidad de revisión o resolución del contrato, desde que, se encuentren cumplidos de forma acumulada los siguientes puntos, (a) esté en vigor un contrato de ejecución continuada o diferida, (b) haya ocurrido, probadamente, una alteración radical de la base del negocio jurídico, coma frustración de la finalidad del contrato, entendida como el cambio concreto de las condiciones y/o circunstancias existentes al momento de la celebración del contrato, en conflicto con las del momento de su ejecución $\mathrm{y}$, finalmente, (c) la onerosidad excesiva surgida del contrato tenga la cualidad de imponer un sacrificio desmedido e injusto para una de las partes, y un beneficio exagerado para la otra, merced (d) a la existencia de factores imprevisibles notificadores de aquella modificación.

\section{- XI -}

Es menester, por lo tanto, que como deflagrador de la invocación de tal teoría, surja un acto o hecho sobreviniente e imprevisto en la relación contractual originaria, al punto de modificar, considerablemente, la situación existente en la ocasión de la 
celebración del contrato (base del negocio), perjudicando a una de las partes al momento de la ejecución del mismo. Dicho acontecimiento sobreviniente, si pudiese ser fácilmente previsto, no habría llevado a los contratantes a la realización del contrato.

Sin embargo, la mayoría de las veces, no es necesaria la cualidad de extraordinario del hecho (si bien que, en la mayor parte de los casos, el factor extraordinario también esté presente), sino apenas la prueba de un acontecimiento imprevisto, que muestre la destrucción de la base del negocio, que provoque una desproporción en el cumplimiento de la obligación o una onerosidad excesiva.

\section{- XIII -}

Se busca así, rescatar la base originaria del negocio y restablecer un equilibrio entre las prestaciones debidas, de tal forma que la ventaja de una de las partes no pueda ser tan significativa, al punto de provocar la ruina de la otra, todo ello, teniendo como soporte y 
base fundamental la buena fe de los contratantes. Debe perseguirse, en especial, en vista de la franca necesidad de mantenerse una dinámica funcional de los contratos y un tráfico seguro de las obligaciones contractuales, el pleno reconocimiento al derecho de calibración, modulación, recomposición y adaptación de los acuerdos celebrados, de modo de preservar el equilibrio inicialmente querido por las partes, con la adopción de posturas objetivas, de índole judicial o extrajudicial, estribadas, siempre, en la buena fe, en los principios integradores del sistema jurídico positivo vigente y en la lealtad contractual.

El concepto "estando así las cosas", en rigor, piedra de toque de la teoría de la imprevisión, representa los mismos dictámenes de principios que sostienen la construcción de la Teoría de la Base del Negocio Jurídico, pautado en la buena fe objetiva, como cláusula general, siempre existente en los sistemas más avanzados de derecho privado. 
De ahí que, integrando el temario, la teoría de la imprevisión, como primer objetivo, tiene por finalidad la revisión del contrato, y no su resolución. Esto no significa, sin embargo, que la parte perjudicada no pueda, también, como fuera afirmado, y bajo ciertas circunstancias, pleitear su resolución, puesto que si la continuidad del acuerdo le es perjudicial, nada obsta a que sea electa esta vía. No obstante, debe optarse, inicialmente, por la conservación del contrato (principio de la conservación de los negocios jurídicos), modificándose, así, las cláusulas contrarias a la equidad, que estén provocando el desequilibrio en el vínculo contractual.

\section{- XVI -}

La interpretación del contrato, de esta manera, a los efectos de la efectiva aplicación de la teoría de la imprevisión, en el caso concreto, debe ser hecha por el magistrado. En otras palabras, la valoración de la posible imprevisibilidad debe ser realizada por el Estado-juez, al no haber solución amigable (o por la justicia privada, a través de los respectivos árbitros, habiendo los contratantes optado por esa forma de resolución del conflicto). 


\section{$-X V I I-$}

La posibilidad de mantenimiento de los contratos, por la flexibilización, en última instancia, de la cláusula "pacta sunt servanda", normalmente ejecutada por el juez, está ideológicamente afinada con los principios mayores relacionados a la preservación de los valores existenciales y de la propia protección de la persona humana, que incluyen en su amplio espacio el resguardo de la dignidad de la persona, de la justicia social y de la construcción de una sociedad cada vez más libre y democrática.

\section{$-X V I I I-$}

No debe olvidarse que, en el ámbito de la valoración y efectiva aplicación, en los casos concretos, de la teoría de la imprevisión, esta debe ser la tarea de los operadores del derecho de vanguardia, hasta por que dicho trabajo está alineado y afinado con la función que les es propia desde los tiempos del Derecho Romano, o sea, moldear y mediar las alternativas existentes, relacionadas con la creación de las leyes, orientación e interpretación de la legislación existente, elaborando, consecuentemente, bajo una perspectiva histórico-dogmática, las proposiciones de solución de los problemas prácticos surgidos en la 
Alteración de las Circunstancias y Revisión Contractual

práctica cotidiana, en el siempre dinámico y esplendoroso universo de los contratos. 
Alteración de las Circunstancias y Revisión Contractual

BIBLIOGRAFÍA 


\section{BIBLIOGRAFÍA}

- ABATTI, E. L. y otros, “La Imprevisión Contractual”, La Ley, T. 1982-C, Buenos Aires, 1982.

- ALBADEJO, M., "Modificacion del Contrato por alteración de las circunstancias", Compendio de Derecho Civil, subsección $3^{\circ}$, Edisofer, Madrid, 2007.

- ALMEIDA, FERNANDES R., "Revista Justitia" del Ministerio Público de SãoPaulo, Vol. 148, São Paulo, 1989.

, "A alteração das circunstãncias nos contratos empresariais e a cláusula hardship”, ponencia presentada ante el I Congresso de Direito Comercial, São Paulo, Brasil, 2011.

$-$ , "Impresiones sobre la buena fe en el Derecho Procesal Civil Brasileño", ponencia presentada ante el III Congreso Nacional de Práctica Profesional, Azul, Argentina, 2009. 

, “A cláusula 'pacta sunt servanda' $e$

a teoria da imprevisão", poenencia presentada ante el XIV Congresso Ibero-Americano de Direito Romano y XI Congresso Internacional de Direito Romano, Lisboa, 2009.

- ALTERINI, A. y otros, "Derecho de obligaciones civiles y comerciales”, Abeledo-Perrot, Buenos Aires, 1995.

- ALVIM, A., "A argüição de relevância no recurso extraordinário", Revista dos Tribunais, $1^{\text {a }}$ edición, 1988, p. 55.

- AMIGO, M., "Idea del contrato: 50 años después (consideraciones previas a una definicion del contrato)", artículo obrante en "Estudios de Derecho de Obligaciones" - Homenaje al Profesor Mariano Alonso Pérez - Coordinador Eugenio Llamas Pombo, Tomo I, La Ley, Buenos Aires, 2006.

- ARGUELLO, L.R., "Manual de Derecho Romano. Historia e Instituciones”,Astrea, Buenos Aires, 1981.

- ARISTÓTELES, “Ética a Nicômacos”, UNB, Brasilia, 2001, traducción de Mario da Gama Cury. 
- ASCENSÃO, J. de O., "Questões controvertidas no novo Código Civil - Alteração das circunstâncias e justiça contratual no novo Código Civil”, Método, São Paulo.

- AZEVEDO, A., “Teoria das Obrigações”, São Paulo, 1999.

- BAUMAN, Z., “Modernidade líquida”, Zahar, Río de Janeiro, 2001

- BAREA, M., “La imposibilidad de cumplir los contratos”, III.4. - 'La excesiva onerosidad de la prestación”.

- BÁRTOLO, de S. , “Omnia quae extam opera”, Vol. II, Venecia, 1603.

- BENSON, P., "The unity of contract law”, New essays, Cambridge University Press, Cambridge, 2001.

- BERNARDES DE MELLO, M., “Teoria do Fato Jurídico”,4ª edición, Saraiva, São Paulo, 1991, pp. 149/150.

- BETTI, E., “Teoria general de las obligaciones", traducción de José Luiz de los Mozos, Tomo I, Revista de Derecho Privado, Madrid. 
- BITTAR FILHO, C.A., "Teoria da Imprevisão: sentido atual", Revista dos Tribunais, Vol. 679, São Paulo, mayo de 1992.

- BOBBIO, N., "A Era dos Direitos", traducción de Carlos Nelson Coutinho, Campus, Río de Janeiro, 1992.

- BONASSO, M., El Palacio y la Calle, Planeta, Buenos Aires, 2002.

- BONNECASE, J., "Derecho de las Obligaciones y los Contratos y del Crédito", traducido por J. Cajica, in "Elementos de derecho Civil", Vol. XV, Tomo II, Cajica, México D.F., 1945.

- BLUM, B., “Contracts - Examples \& Explanations", Aspen Publishers, Nueva York, 2004.

- BULGARELLI, W., “Contratos Mercantis”, Atlas, São Paulo.

- CAMPOS, F., “Revisión de los Contratos: Teoría de la Imprevisión”, Derecho Civil. 
- CANNARIS, C.W., "Pensamento Sistemárico e Conceito de Sistema na Ciência do Direito", $4^{a}$ edición, Fundação Calouste Gulbenkian, Lisboa.

- CARNELUTTI, F., “Metodologia do Direito”, traducción de Frederico Paschoal, Bookseller, Campinas, 2002.

- CARVALHO DE MENDONÇA, J.X., "Tratado de direito comercial brasileiro”, Freitas Bastos, Río de Janeiro, 1964.

- CARVALHO FERNANDES, “A teoria da imprevisão no direito civil português”, Quid Júris?, Lisboa, 2001.

- CARVALHO, S., "Repertório enciclopédico de direito brasileiro", Vol. XI, Borsoi, São Paulo.

- CASTRO Y BRAVO, F., "El negocio jurídico y la persona jurídica”, Vol III, in "Derecho Civil de España", Thomson Civitas, Navarra, 2008.

- CATALÁN, M.J., "Descumprimento contratual”, Juruá, Curitiba, 2005. 
- COELHO UlLOA, F., "Manual de Direito Comercial", 15ª edición Saraiva, São Paulo, 2004.

- CORDEIRO MENEZES, A., "Da modernização do Direito Civil”, Vol. I, Almedina, Coimbra, 2004.

- CORREIA, A y outro, "Manual de Direito Romano”, Vol I, Saraiva, São Paulo, 1955.

- COSTA, J. de A., "Direito das Obrigações", 4a edición, Coimbra Editora, Coimbra, 1984.

- CUNHA GONZÇALVES, "Tratado de Direito Civil”, en "Comentário do Código Civil Português", Vol V, Coimbra Editora, Coimbra, 1932.

- CUNHA, P. , "Direito das Obrigações”, Tomo II, Baroeth, Lisboa, 1938 / 1939..

- DALTON, C., "An essay in the deconstruction of contract doctrine", L.J., Yale, 1985. 
- DE PLACIDO E SILVA, "Noções práticas de direito comercial", actualizado por Waldir Vitral, 14 a edición, Forense, Río de Janeiro, 1998.

- DIAS, E., “Instituciones de Derecho Romano”, 6 edición, ampliada y anotada por Juan Iglesias, T. I, Horta, Barcelona, 1947.

- DIAS, M. L., “Da revisão judicial dos contratos pela aplicação da teoria da imprevisão”, Revista da Pontifícia Universidade Católica de São Paulo, Brasil.

- DICCIONARIO DE LA LENGUA ESPAÑOLA, de la Real Academina Española, Madrid, 1970.

- DIEZ PICAZO, L., "Fundamentos del derecho civil patrimonial”, Tecnos, Madrid, 1970.

, "Extinción de obligaciones", Director José Ramón Ferrandiz Gabriel, "La cláusula rebus sic stantibus”, Consejo General del Poder Judicial, Madrid, 1996.

$-$ , "Sistema de Derecho Civil”, Vol. II, 9ª edición,

Tecnos, Madrid. 
- DINIZ, M.H., "Curso de Direito Civil Brasileiro - Teoria das obrigações contratuais e extracontratuais”, 26 edición, Saraiva, São Paulo, 2009.

- ENNECERUS, L., "Derecho de Obligaciones”, traducción de Blas Pérez González y José Alguer, Vol I, 35ª edición alemana, Bosch, Barcelona, 1933.

- FERREYRA, E., "Principales efectos de la contratación civil". Depalma, Buenos Aires, 1978.

- GAMARRA, J.,"Imprevisión y equivalencia contractual", in Cuadernos del Anuario de Derecho Civil Uruguayo, Fundación Cultura Universitaria, Montevideo, 2006.

- GHERSI, C., “Reparación de daños contractuales producidos por la emergencia económica”, Nueva Tesis, Buenos Aires, 2002, p. 105.

- GOMES, O., "Transformações Gerais do Direito das Obrigações", Forense, Río de Janeiro. 
Alteración de las Circunstancias y Revisión Contractual

- — Parecer incluído en la obra "Dos contratos internacionais: uma visão teórica e prática”, Luiz Olavo Batista, Saraiva, São Paulo, 1994.

- GOYENA GARCÍA, F., “Comentarios, motivos y concordancias del Código Civil español”, T. III, Madrid, 1852.

- GRECO FILHO, V., "Direito Processual Civil Brasileiro”, Vol. II, $16^{\text {a }}$ edición, Saraiva, São Paulo, 2003, p.106.

- HAMURABI, “Código de Hamurabi”.

- IHERING, R., “El fin en el derecho (1872)”, Heliasta, Buenos Aires, 1978.

- PESSOA, J., "Lições de Direito das Obrigações", Associação Acadêmica, 1975.

- JOSSERAND, L., “De l'esprit des droits”, nº 119. 
Alteración de las Circunstancias y Revisión Contractual , "Tendences actuelles de la Théorie des contracts”, R.T., 1937, p.21 y ssgtes.

- KLANG, M., "A teoria da imprevisão e a revisão dos contratos", Revista dos Tribunais, Río de Janeiro, 1983.

- LARENZ, K., "Allgemeiner Teil des destschen burgerlichen /rechts", 8. aufl., Beck, Munich, 1997, con Manfred Wolf.

, "Base del negócio juridico y cumplimento de los contratos”, traducción de Fernandez Rodriguez, Revista de Derecho Privado, Madrid, 1956.

$-$ , "Metodologia da ciência do Direito", 2" edución, traducción de la $5^{\text {a }}$ edición alemana, Fundación Calouste Guebekian, Lisboa, 1983.

- LASARTE, ALVÁREZ, C., "Manual sobre protección de consumidores y usuarios”, Dykinson, Madrid, 2003.

, "La alteración de las circunstancias contractuales: La cláusula 'rebus sic stantibus", in Principios de Derecho Civil, T III, Contratos, $4^{\circ}$, Trivium, Madrid. 
- LOMBARDI, A., "La Rizoluzione per Impossibilita Sopraventa - la Presupposizione: Protili Generali”, Giceffré, 2007, pp. 353/354.

- LORENZETTI, R., “La economía del derecho: la culpa y el riesgo”, Responsabilidad por daños, Homenaje a Bustamante Alsina, Abeledo Perrot, Buenos Aires, 1990.

_- "Redes contractuales. Conceptualización jurídica, relaciones internas de elaboración, efectos frente a terceros", Revista de Direito do Consumidor, São Paulo, no 28/30.

- MARKY, T., “Curso elementar de Direito Romano”, Saraiva, São Paulo, 1995.

- MARQUES, C.L., "Contratos no Código de Defesa do Consumidor”, Revista dos Tribunais, São Paulo, 1998.

- MARSHALL, T., “Cidadania, classes sociais e status”, Zahar, Río de Janeiro, 1967.

- MARTINEZ, P.R., “Da cessação do contrato”, $2^{\mathrm{a}}$ edición, Almedina, Coimbra. 
- MARTINS, F., “Contratos e obrigações comerciais”, 14ª edición, Forense, Río de Janeiro.

- MATTOS NETO, “A cláusula 'rebus sci stantibus' e a cláusula de escala móvel”, Revista de Direito Civil, Agrario e Empresarial, $\mathrm{n}^{\circ}$ 63, São Paulo, enero / junio de 1993.

- MAYO, J.A., "Estudios de Derecho Civil - Parte general obligaciones, responsabilidad civil - Contratos”, La Ley, Buenos Aires, 2005.

- MESSINEO, F., "Doctrina General del Contrato”, traducción de R. O. Fontanarrosa, Sentis Melendo y M. Volterre, Tomo II, Ediciones Jurídicas Europa - América, Buenos Aires, 1986.

— "Derecho Civil y Comercial", traducción de S. Sentis Melengo, tomo III, Ediciones Jurídicas Europa - América, Buenos Aires, 1954.

- MOJER, M.A., "El negocio jurídico - Un estudio introductorio al campo de las obligaciones romanas”, La Ley, Buenos Aires, 2002.

- MONTEIRO, W., "Curso de direito civil: direito das obrigações”, Vol. IV, 29ª edición, Saraiva, São Paulo, 1997. 
- MORELlO, A. y otro, "Imprevisión cambiaria y revisión del contrato”, Jurisprudencia Argentina, Buenos Aires, 16/9/1981.

- MOSSET ITURRASPE, J., "Interpretación económica de los contratos", Rubinzal-Culzoni, Buenos Aires, 1994, p. 31.

"Responsabilidad por daños", Rubinzal - Culzoni, Buenos Aires, 1971.

- NALIM, P., "Do contrato: conceito pós-moderno em busca de sua formulação na perspectiva civil-constitucional”, Juruá, Curitiba, 2001.

- NERY JUNIOR, N., "Revista de Direito Privado" (n¹79), Editorial Revista dos Tribunais.

y otra, - "Código Civil comentado e legislação extravagante”, $3^{\text {a }}$ edición, Revista dos Tribunais, 2005.

- NORONHA, F. "O direito dos contratos e seus principios fundamentais: autonomia privada, boa-fé, justicia contractual”, Saraiva, São Paulo, 1994. 
- OERTMANN, P., "Die geschäftsgrundlage; ein neuer rechtsbegriff" (Base del negocio: un nuevo concepto jurídico), A. Deichertsche Verlagsbuchhandlung Dr. Werner scholl, Leipzig, 1921.

- OROZIMBO, N., "Curso de obrigações: generalidades - espécies" Forense, Río de Janeiro, 1960.

- OSTI, G., “Contratto”, Novíssimo Digesto Italiano.

- ___ "Revione critica della teoría sulla impossibilitá della prestazione”, Riv. Dir. Civ., 1918.

- PERLINGIERI, P., "Códice civile annotato con La dottrina e La giurisprudenza”, Libro Cuarto, UTET.

- PÉREZ, A., "Decretos de necesidad y urgencia. Límites y control”, Depalma, Buenos Aires.

- PÉREZ, J.A., "La rescisión del contrato" - "En torno a la lesión contractual y el fraude de acreedores”, Bosch, Barcelona, 1995.

- PIERES DE LIMA A. y Otro, "Código Civil Anotado", Vol. I, Coimbra Editora, Coimbra, 1967. 
- PONTES DE MIRANDA, F., "Tratado de Direito Privado - Parte Especial”, Tomo XXV, Borsoi, p.221.

- POTHIER, R., “Tratado das Obrigações”, $1^{a}$ edición, traducción de Douglas Dias Ferreira y Adrian Sotero Batista, Servanda, São Paulo, 2002

- RASELLI, A., “Il potere discrezionale del giudice”, Giuffrè, Milán, 1975.

- REALE, M., “Visão Geral do Projeto do Código Civil”, Saraiva, São Paulo, 1986.

- RODRIGUES, S., “Derecho Civil”, Vol. III, Saraiva, São Paulo, 1982.

- RULLE, D., “Hasard et chaos”, Odile Jacob, París, 1991.

- SAN AGUSTÍN, “Sermones Adpopulum”, 133. 
- SASTRE ROCA, in "Estudios de Derecho Privado", vol. I, Capítulo VII, "El problema de la alteración das circunstancias", elaborado con la colaboración de JOSÉ PUIG BRUTAL, Madrid, 1948.

- SCHAPP, Jan, "Derecho Civil y Filosofia del Derecho - La liberdad em el Derecho”, Universidad Externado de Colombia, Bogotá, 1998, pp. $73 / 74$.

- SERPA LOPES, M., “Curso de direito civil”, Vol. III, $3^{\text {a }}$ edición, Río de Janeiro, 1991.

- SHAKESPEARE, W, “O mercador de Veneza”, Lacerda, Río de Janeiro, 1999.

- SIDOU, J.M, "A revisão judicial dos contratos e outras figuras jurídicas: a cláusula "rebus sic stantibus", Forense, Río de Janeiro, 1978.

- SILVA MELO, "Contratos internacionais e cláusula de hardship”, Aduaneiras, São Paulo, 2000.

- SILVEIRA, A., "Hermenêutica do Direito Brasileiro", Revista dos Tribunais, 1968, Vol. I, p. 83. 
- SINGER, R., "Direitos Fundamentais e Direito Privado - uma perspectiva de direito comparado", Organizadores Anotonio Pinto Monteiro y otros, Almedina, Coimbra.

- SMITH. A., “The Wealth of Nations”, Metalibri Digital Library.

- TELlES, I.G., "Direito das Obrigações", $7^{\mathrm{a}}$ edición, Coimbra Editora, Coimbra, 1997.

- TELLO, R., "La teoria de La imprevisión em los contratos de derecho publico”, Valerio Abeledo, Buenos Aires, 1946.

- TOSTA, J., "Manual de Interpretação do Código Civil - as normas de tipo aberto e os poderes do juiz”, $1^{a}$ edición, Campus Jurídico.

- VARELA, J de M.A., "Das obrigações em General”, 2a Edición, Volumen I, Almedina, Coimbra.

- VELENCOSO, M., "La alteración de las circunstancias contractuales", Thomson Civitas, Navarra, 2003. 
Alteración de las Circunstancias y Revisión Contractual

- VIVANTE, C., "Instituições de Direito Comercial”, traducción de Ricardo Rodrigues Gama, LZN, 2003.

- WALD, A., “Obrigações e contratos”, Revista dos Tribunais, São Paulo, 2000.

- WINDSCHEID, B., "Die lehre dês römischen rechts von der voraussetzung”, Verlagsbuchhandlung von Julius Buddeus, Düsseldorf, 1850.

, "Dirittto delle Pandette", traduccuión de Carlo Fadda y Paolo Emilio Pensa, UTET, Turín, 1902.

- ZIMMERMANN, R., "El nuevo derecho Alemán de obligaciones"traducción de Esther Arroyo y Amayeales, Bosch, Barcelona, 2008, pp. $49 / 50$. 